San Jose State University

SJSU ScholarWorks

Master's Theses

Master's Theses and Graduate Research

1990

\title{
An analysis of the solos in George Frideric Handel's Chandos Anthems for the purpose of revoicing
}

Brenda Joyce Davidson

San Jose State University

Follow this and additional works at: https://scholarworks.sjsu.edu/etd_theses

\section{Recommended Citation}

Davidson, Brenda Joyce, "An analysis of the solos in George Frideric Handel's Chandos Anthems for the purpose of revoicing" (1990). Master's Theses. 3254.

DOI: https://doi.org/10.31979/etd.jkmx-q4zk

https://scholarworks.sjsu.edu/etd_theses/3254

This Thesis is brought to you for free and open access by the Master's Theses and Graduate Research at SJSU ScholarWorks. It has been accepted for inclusion in Master's Theses by an authorized administrator of SJSU ScholarWorks. For more information, please contact scholarworks@sjsu.edu. 


\section{INFORMATION TO USERS}

The tnost advanced technology has been used to photograph and reproduce this manuscript from the microfilm master. UMI films the text directly from the original or copy submitted. Thus, some thesis and dissertation copies are in typewriter face, while others may be from any type of computer printer.

The quality of this reproduction is dependent upon the quality of the copy submitted. Broken or indistinct print, colored or poor quality illustrations and photographs, print bleedthrough, substandard margins, and improper alignment can adversely affect reproduction.

In the unlikely event that the author did not send UMI a complete manuscript and there are missing pages, these will be noted. Also, if unauthorized copyright material had to be removed, a note will indicate the deletion.

Oversize materials (e.g., maps, drawings, charts) are reproduced by sectioning the original, beginning at the upper left-hand corner and continuing from left to right in equal sections with small overlaps. Each original is also photographed in one exposure and is included in reduced form at the back of the book.

Photographs included in the original manuscript have been reproduced xerographically in this copy. Higher quality 6" $\times 9$ " black and white photographic prints are available for any photographs or illustrations appearing in this copy for an additional charge. Contact UMI directly to order.

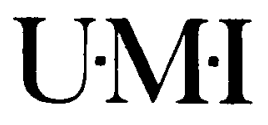

University Microfilms International

A Bell \& Howell Information Company

300 North Zeeb Road. Ann Arbor, MI 48106-1346 USA

$313 / 761-4700 \quad 800 / 521-0600$ 

Order Number 1340507

An analysis of the solos in George Frideric Handel's Chandos Anthems for the purpose of revoicing

Davidson, Brenáa Joyce, M.A.

San Jose State University, 1990 


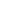


AN ANALYSIS OF THE SOLOS IN

GEORGE FRIDERIC HANDEL'S CHANDOS ANTHEMS

FOR THE PURPOSE OF REVOICING

\author{
A Thesis \\ Presented to \\ The Faculty of the Department of Music \\ San Jose State University \\ In Partial Fulfillment \\ of the Requirements for the Degree \\ Master of Arts
}

\author{
By \\ Brenda Joyce Davidson \\ May, 1990
}


APPROVED FOR THE DEPARTMENT OF MUSIC

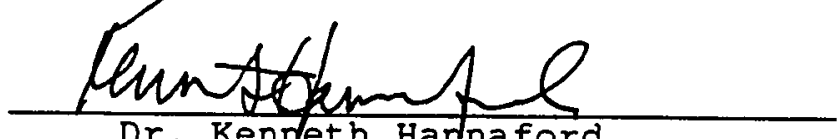

Dr. Kenneth Hannaford

Hellim B. Horee

Dr. William B! George

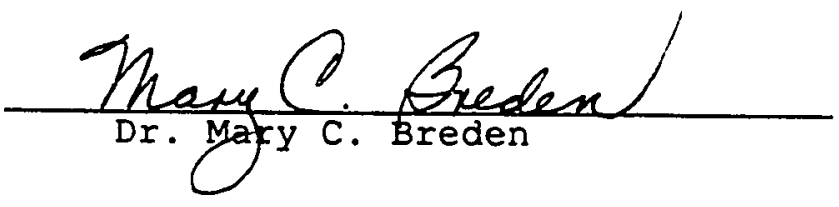

APPROVED FOR THE UNIVERSITY

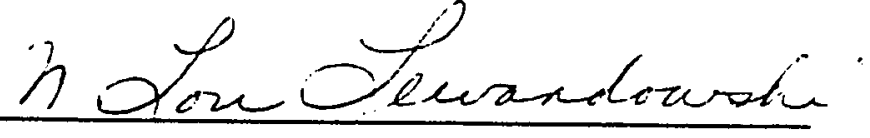




\section{ABSTRACT}

AN ANALYSIS OF THE SOLOS IN

GEORGE FRIDERIC HANDEL'S CHANDOS ANTHEMS

FOR THE PURPOSE OF REVOICING

by Brenda Joyce Davidson

This thesis is an analysis of the solos in George Frideric Handel's Chandos Anthems for the purpose of revoicing. The anthem solos, and other selected works, were examined to identify any significant considerations or compositional techniques which are associated with a particular voice. This thesis discusses whether it is possible to reassign a solo to a voice other than the one indicated and still maintain the composer's intentions and the integrity of the composition. The analysis concentrates on compositional techniques in five areas: instrumentation, style, text subjects, position in work, and Handel's reuse of solos.

Research indicates it is possible to revoice solos in the Chandos Anthems, with careful consideration. This thesis produces guidelines for reassigning a solo to another voice. 


\section{ACKNOWLEDGEMENTS}

A master's degree candidate has certain expectations of a thesis supervisor and relies heavily on that person for help and guidance. Occasionally a student is fortunate in having a supervisor who goes beyond what is normally expected. Dr. Kenneth Hannaford has been this kind of supervisor, and his extra time and concern have been very much appreciated.

I also owe an immense debt to Marilyn and Meryl, two wonderful friends, whose loan of a computer made it much more converient for me to write this thesis. 
TABLE OF CONTENTS

Page

ABSTRACT . . . . . . . . . . . . . . . . . . . iii

ACKNOWLEDGEMENTS . . . . . . . . . . . . . . . . . . iv

LIST OF TABLES . . . . . . . . . . . . . . . . . . . v

LIST OF MUSICAL EXAMPLES . . . . . . . . . . . . . . . vi vi Chapter

1. INTRODUCTION . . . . . . . . . . . . . . . . . i

Statement of the Problem . . . . . . . . 1

Purpose of the Study . . . . . . . . . 2

Delimitations of the Study . . . . . . . 2

Related Literature . . . . . . . . . 3

Justification for Study . . . . . . . . . 5

Procedure of Study . . . . . . . . . . 7

2. HISTORICAL BACKGROUND . . . . . . . . . . . . 9

Handel Before Cannons . . . . . . . . . 9

Handel and the Duke of Chandos . . . . . 12

Music and Musicians at Cannons . . . . . 14

3. OVERVIEW OF THE CHANDOS ANTHEMS . . . . . . . 20

Purpose . . . . . . . . . . . . . 20

Chronology and Numbering . . . . . . . . 22

Description of the Anthems . . . . . . . 25 
4. ANALYSIS OF SOLOS . . . . . . . . . . . 32

Instrumentation . . . . . . . . . 33

Style . . . . . . . . . . . . 40

Text Subjects . . . . . . . . . . . 45

Position in Work . . . . . . . . . . 48

Handel's Reuse of Solos . . . . . . . . 49

5. CONCLUSION . . . . . . . . . . . . . 60

Summary . . . . . . . . . . . . 60

Guidelines . . . . . . . . . . . 62

APPENDIXES

A. SChEMATIC OF MOVEMENTS IN THE

CHANDOS ANTHEMS . . . . . . . . . . 66

B. SOLOS IN THE CHANDOS ANTHEMS AND

CHAPEL ROYAL WORKS . . . . . . . . . 68

C. MUSICAL SCORES OF SOLOS IN CHANDOS

ANTHEM VIII, O COME, IET US SING

UNTO THE IORD . . . . . . . . . . . . . . 74

BIBLIOGRAPHY . . . . . . . . . . . . . . . . . . 92 


\section{IIST OF TABLES}

Table

Page

1. Anthems As Published. . . . . . . . . . 24

2. Proposed Tentative Chronology . . . . . . . 25

3. Instrumentation of Solos in the Chandos Anthems and Chapel Royal Works . . . . . 34

4. Meter and Tempo for the Solos in the Chandos Anthems and Chapel Royal Works . . 44

5. Subject Matter for the Solos in the Chandos Anthems and Chapel Royal Works . . 47

6. Possibilities for Revoicing Solos in Chandos Anthem VIII, e come, let us sing unte the Iord . . . . . . . . . . . 


\section{LIST OF MUSICAL EXAMPLES}

All musical examples are taken from Händel Gesellschaft (H.G.), edited by Friedrich Chrysander.

1. Oboe imitation of canto vocal figure in canto solo, "My song shall be alway" from Chandos Anthem VII, My song shall be alway (H.G. v. 35, p. 7) . . . . . . . 36

2. Oboe imitation of tenor vocal figure in tenor solo, "The Lord preserveth" from Chandos Anthem VIII, 0 come let us sing unte the Lord (H.G. v. 35, p. 85) . . . . .

3. Alto vocal imitation of oboe figure in alto solo, "I will magnify Thee," from Chapel Royal Anthem $V-B, I$ will magnify Thee (H.G. v. 34, P. 171) . . . . . . . . . . . 38

4. Continuo doubling of bass vocal line in bass solo, "That God is great" from Chandos Anthem IX, 0 praise the Iord with one consent (H.G. v. 35, p. 121) . . . . . .

5. Comparison of the continuo counterpoint and bass vocal line in bass solo, "Like as the smoke vanisheth" from Chapel Royal Anthem XI-B, Let God arise (H.G. v. 35, p. 277) . . . . . . . . . . . . .

6. Unifying motive in vocal and instrumental lines in tenor solo, "God is a constant sure defense" from Chandos Anthem II, In the Lord put I my trust (H.G. v. 34, p. 51-52) . . . . . . . . . . . . 
7. Unifying sixteenth-nnte rhythmic pattern in tenor solo, "The waves of the sea rage horribly" from Chandos Anthem IV, 0 sing unto the Lord a new song (H.G. V. 34, p. 120). . . . . . . . . . . . . .

8. Unifying rhythmic pattern of continuo running eighths and violin dotted quarters in canto solo, "It is the Lord that ruleth the sea" from Chandos Anthem $x$, The Lord is my light (H.G. v. 35, P. 199) . . . .

9a. Comparison between alto solo, "When Thou took'st upon Thee to deliver Man" from Te Deum for the Peace of Utrecht, 1713 (H.G. v. 31, p. 24), and canto solo, "Make me a clean heart, 0 God," Example $9 b$. . . . . .

9b. Comparison between canto solo, "Make me a clean heart, O God" from Chandos Anthem III, Have mercy upon me (H.G. V. 34, 0. 102), and alto solo, "When Thou took'st upon Thee to deliver Man," Example 9a . . . . . . .

10a. Comparison between tenor solo, "O sing unto the Lord a new song" from Chapel Royal anthem, e sing unto the Lord a new song (H.G. V. 36, p. 219), and soprano solo, "O sing unto the Lord a new song," Example IOb. . . . . . . . . . . . . . .

10b. Comparison between soprano solo, "O sing unto the Lord a new song" from Chandos Anthem IV, o sing unte the Lord a new song (H.G. V. 34, p. 112), and tenor solo, "O sing unto the Lord a new song," Example 10a . . . . . . .

11a. Comparison between tenor solo, "God is very greatly to be fear'd from Chandos Anthem VII, My song shall be alway (H.G. v. 35, p. 14), and countertenor solo, "When Thou tookest upon Thee to deliver man," Example 11b. . .

11b. Comparison between countertenor solo, "When Thou tookest upon Thee to deliver man" from Te Deum in D major, 1714 (H.G. v. 37, p. 12), and tenor solo, "God is very greatly to be fear'd," Example lla... . . . . . . . . 
12a. Comparison between tenor solo, "praise Him all ye that in His house attend" from Chandos Anthem IX, e praise the Iord with one consent (H.G. V. 35, p. 113), and soprano solo, "No more disconsolate I'll mourn," Example 12b

123. Comparison between soprano solo, "No more disconsolate I'Il mourn" from Deborah (H.G. V. 29, P. 164) and tenor solo, "Praise Him all ye that in His House attend," Example 12a . . . . . . . . 56

13a. Comparison between tenor solo, "For this our truest int'rest is" from Chandos Anthem IX, o praise the Lord with one consent (H.G. v. 35, P. 115), and soprano solo, "Our fears are now for ever fled," Example 13b

13b. Comparison between soprano solo, "Our fears are now for ever fled" from the oratorio, Deborah, 1733 (H.G. 4. 29, p. 191), and tenor solo, "For this our truest int'rest is," Example 13a................ 
Chapter 1

INTRODUCTION

\section{STATEMENT OF THE PROBLEM}

Handel's Chandos Anthems, composed for the Duke of Chandos between 1717 and spring 1719, were written for professional and accomplished singers, including countertenors and castrati. Solos are a large and important part of the music in the anthems and can, upon initial examination, render many anthems unsuitable for performance by a choir of less than professional quality. Solos in the anthems often encompass an extreme range and tessitura which would make it difficult, if not impossible, to perform the solos with the voices indicated. A singing group, while capable of performing the choruses in an anthem, may not have solos voices to perform the solos as assigned.

The purpose of this thesis is to analyze the solos in Handel's Chandos Anthems and selected other works to identify any significant considerations or compositional techniques whici are associated with a particular voice. This thesis examines the possibility of reassigning a solo to a different voice while maintaining the composer's intentions and the integrity of the composition. 
II. PURPOSE OF THE STUDY

The purpose of this study is to provide a set of guidelines for choral directors who may consider reassigning an anthem solo to a voice other than the one indicated in the music. While current views on performance practice may not favor this approach, an examination of Handel's performance practices and compositional techniques, together with views expressed by noted historians and musicologists, may provide reasonable grounds for choosing an alternate voice for a solo.

The alternatives to reassigning a solo may not be acceptable or agreeable to a choral director. These include:

1. Hiring a soloist

2. Deleting the solo

3. Using original or facsimile instruments and performing at baroq'e pit.ch $(A=410-420)$

4. Transposing the solo

5. Choosing another work to perform

This study assumes none of the above are viable alternatives and concentrates on the problem of reassigning the solo.

III. DELIMITATIONS OF THE STUDY

This thesis is concerned with the reassignment of solos in the Chandos Anthems to a voice other than that which is 
indicated. The Chandos Anthems, as a body of music, is a distinct entity which is defined by discernible musical and formal characteristics. While they certainly bear some strong relationships to earlier compositions by Handel, as well as other composers, and represent the beginnings of the English oratorio, they are easily recognized as a definable unit.

The solos in the anthems are unique among Handel's music in several ways. They were written for specific singers to accommodate and emphasize their particular abilities. They also acknowledged the preferences of the Duke of Chandos by their lack of viola and alto parts. An important point which distinguishes these solos from operatic and some oratorio solos is the lack of character association. These considerations serve to limit this study by producing guidelines which may only be appropriate for the Chandos Anthems.

\section{RELATED IITERATURE}

There are four studies which have been especially valuable in the research of this topic. They have provided information on historical background, compositional technique, and performance practice. They are: George Erideric Handel, by Paul Henry lang (1966); The chandos Anthems and Te Deum of George Frideric Handel, Ph.D. 
dissertation by Graydon Fisher Beeks, Jr., (1981); Handel's Messiab: exigins, Composition, Sources, Jens Peter Larsen (1972); and, Handel's Dramatic Oratorios and Masques, by Winton Dean (1959).

Lang's Geerge Frideric Handel is the most complete and definitive examination of Handel's development, and forces which affected that development. Beeks' dissertation, The Chandes Anthems and Te Deum of George Frideric Handel, in two volumes, provides a detailed analysis of the musicians, instruments, and musical life at Cannons. Larsen has detailed the factors which influenced both composition and performance of Messiah in Handel's Messiah: Origins, Composition, Sources. Since Messiah is considered an anthem oratorio, the treatment of its solos compares favorably to the solos in the Chandos Anthems. Larsen's study gives some interesting insights to Handel's reuse of solos. While all of Winton Dean's studies have been useful sources, one in particular has been invaluable to the topic of this thesis: Handel's Dramatic eratorios and Masques. This study not only provides detailed historical background and analyses of the works, but details many important aspects of performance practice. 
V. JUSTIFICATION FOR STUDY

An examination of related literature has revealed no significant study in the analysis of the solos in the Chandos Anthems, and the reassignment of those solos to a voice other than the one indicated. A study which examines this subject and provides guidelines for consideration may be helpful to choral directors who consider performing one of the anthems.

Current views on performance practice favor performance of music as indicated by the composer, and as stylistically dictated by the time and place in which it was conceived. Robert Donington noted the increasing interest in authentic performance practice in a recent article: "The fact is that the attempt at authenticity has by now established itself so strongly in the current range of our musical activity that it may be challenged but it cannot be denied."l Authentic performance practice suggests performing the solos in the Chandos Anthems exactly as indicated. Reassigning a solo to a part other than the one indicated, when the designated voice part is unsuitable for the available singers, may, however, be an alternative which would allow an acceptable

1 Robert Donington, "The Present Position of Authenticity," Performance Practice Review, Vol. 2, No. 2 (Fall, 1989), 120. 
performance of the solo without sacrificing the composer's intentions.

It is unfortunate that these anthems are rarely performed. As a body of literature, the Chandos Anthems represent all the various components of Handel's choral and vocal compositional technique. Their value is proclaimed by many noted historians and musicologists.

Handel laid the cornerstone for his future choral compositions in the twelve "Chandos Anthems", composed before 1720. . . They are great orchestral cantatas in which the choruses form the solid pillars, and the solos, duets and recitatives the lofty arches of a grand and imposing architecture. 2

Considered as a set, the Chandos Anthems represent almost every aspect of Handel's work, and his greatness in its various aspects of power, charm and pathos could be measured here, were all his other works lost. 3

Handel's Chandos Anthems. . . were always very popular in England, and are rightly considered among the most magnificent psalm settings in the entire literature. ${ }^{4}$

2 Manfred E. Bukofzer, Music in the Baroque Era, (New York: W. W. Norton \& Co., Inc., 1947), 333.

3 Basil Lam, "The Church Music," Handel: A Symposium, edited by Gerald Abraham. (London: Oxford University Press,
1954), 175.

4 Paul Henry Lang, "Handel's Chandos Anthems: Ceremonial Music That Makes a Glorious Sound, "High Fidelity, Vol. 19, 
The musical value of the Chandos Anthems and the lack of a solution for revoicing the solos in the anthems indicate the need for the research presented in this thesis. This document will provide information not readily available and may be a helpful performance aid.

$$
\text { VI. PROCEDURE OF STUDY }
$$

The research and study presented in this thesis includes an analysis of the solos in the Chandos Anthems and selected other works. The analysis concentrates on compositional techniques in five categories.

1. Instrumentation is charted to determine if a particular instrument or instrumentation is peculiar to a voice type.

2. Style - Formal aspects of the music are noted, as well as harmonic and melodic content, to identify discernible patterns.

3. Text subjects are analyzed and compared to determine whether a subject is associated with a voice type, as in opera and operatic oratorio, where character types were most often associated with specific voice types.

4. Resition in work - Note is given to the order in which solos were assigned to voice types and to their position in the work to identify any patterns which might affect reassigning the solos. 
5. Handel's reuse of solos in the anthems and selected other works were studied to reveal compositional changes made when he used another voice for the solo. An analysis was made to determine if there were any consistent patterns which would be applicable to reassigning solos in the Chandos Anthems.

Where possible, scores were studied from both Händel Gesellschaft, edited by Friedrich Chrysander, and Hallische Händel-Ausgabe, edited by Walther Siegmund-Schultze.

The results of this study have been summarized in a set of guidelines which may be beneficial to choral directors and soloists who are considering reassigning a solo in the anthems to a voice other than the part indicated. 
Chapter 2

HISTORICAL BACKGROUND

\section{HANDEL BEFORE CANNONS}

Georg Friedrich Handel's distinguished appointment as court conductor in Hanover was effective on June 16, 1710, when Handel was only twenty-five years of age. One of the stipulations in his contract was the agreement to extended leaves of absence. After only five or six months, he was granted a year's leave to travel to London. The British nobility were beginning to accept opera as an important social and political function and Handel was already an established master of Italian opera. Rinalde, Handel's first opera in London, was first performed on February 24, 1711. This Italian-style opera was an immediate success and Lang says,". . rightfully so, because. . Binalde is one of Handel's great operas; from the overture, a spacious piece, the music flows beguilingly."l Handel was instantly accorded recognition as a great artist. He was welcomed in the highest intellectual and social levels and, by the end of the opera season and his return to Hanover, Handel had even paid his respects to Queen Anne and received gifts from her.

1 Paul Henry Lang, George Frideric Handel, (New York: W. W. Norton \& Co., Inc., 1966), 119. 
June, 1712 saw Handel's return to Hanover. There was no opera in Hanover and very little musical stimulation for Handel, and in October, he was granted another leave to return to London. This time he made London his home.

Handel's return to the operatic scene was at first met with failure. His success was insured and his reputation restored, however, with ode for the Birthday of oveen Anne and the Te Deum for the Peace of Utrecht. ode for the Birthday of Queen Anne was performed at court on February 6 with singers from the Chapel Royal. The Queen was very pleased with Handel's excellent music and honored him by granting a commission to write the Te Deum for the peace treaty celebration with Georg Iudwig of Hanover. When the Queen heard the Te Deum, she was so delighted she granted Handel an annual pension of 200 pounds, even though he was not yet a British citizen. Handel's reputation as a great artist and his social standing in British society was secure. After the Queen's death on August 1, 1714, Georg Ludwig of Hanover became King George I of England. Although Handel was reportedly uneasy about his extended absence from Hanover, it appears the new king bore him no ill will. Handel continued composing for King George and the Chapel Royal, and enjoyed two more highly successful seasons in opera. Handel was also a personal friend of Caroline, the Princess of Wales, and 
believed to have been music master to the Prince and Caroline's three daughters. ${ }^{2}$

Handel was feted as a great artist, respected as an intellectual, and enjoyed as a social companion.

\begin{abstract}
iiterar he was undeniably gifted with a well-defined - iry taste and an extraordinary knack of tongues. Friends in later life, treasuring his powers as a raconteur, found that they needed to know at least four or five languages in order to appreciate his stories. 3
\end{abstract}

Handel's artistic tastes are also well-documented. He loved visiting picture auctions in London and owned two Rembrandts.

With a life which appeared comfortable and rewarding, it is surprising to note Handel's absence from the London scene for almost two years. Winton Dean said,

From his complete disappearance between the water Concert of 17 July 1717 and February 1719, during which period the newspapers contain not a single reference to his activities, it is safe to conclude that he was out of Iondon. 4

A letter written by the Duke of Chandos to his friend Dr. Arbuthnot on September 25, 1717, establishes Handel's employment at Cannons approximately late in the summer of

2 Ibid. 108-109, 133.

3 Jonathan Keates, Handel: The Man and His Music, (New York: St. Martin's Press, 1985), 15.

4 winton Dean, Handel's Dramatic Oraterios and Masques, (New York: Oxford University Press, 1959), 159. 
1717. Whether the declining popularity of opera or the strained relations between Handel's two friends, King George and Prince George, was responsible, Handel left London for employment with the Duke of Chandos at Cannons.

\section{HANDEL AND THE DUKE OF CHANDOS}

James Brydges was a very wealthy man who made his fortune primarily through illegal means. His crimes were never proved and his charming manner earned him acceptance among the nobility.5 He was one of the most noted patrons of the arts and was most favorably impressed with Handel. Mr. Brydges' good relations with George I earned him the title of Earl of Caernarvon, although it did require some political maneuvering. Brydges' father, Lord Chandos, was made Earl of Caernarvon one day prior to his death. Upon the Earl's death, Brydges became technically the second Earl of Caernarvon. Because of the questionable circumstances under which he gained his wealth, the king could not name Brydges the first Earl, but naming his father the first Earl was an eminently suitable compromise. This allowed the title to be passed to Brydges. On April 29, 1719, the King then named Brydges the First Duke of Chandos.

5 Lang, 140. 
Brydges had purchased Cannons from his first wife's family prior to 1713. He used his considerable wealth to redesign and refurbish Cannons in an Italian baroque style, palatial enough for royalty. Lang says the Duke maintained a "sumptuous princely household."6 In keeping with his exalted state of living, the Duke hired his own singers and musicians to provide music such as few of the nobility could claim. In addition to the singers and musicians who worked at Cannons in both music and household positions, the Duke hired professionals from the London theater. His musical interests and the state of music at Cannons seem to have presented an agreeable situation for Handel.

During the summer of 1717, Handel accepted employment with the Duke. His employment arrangements are unknown, but Handel appears to have acted as music master and resident composer. His name does not appear in any wage records, however, leading to speculation that he may not actually have been in residence at Cannons. Nevertheless, it is known he composed music primarily for the Duke from 1717 to spring 1719. One of Handel's biographers remarked that ". . .having such a Composer, was an instance of 'real' magnificence, such as no private person or subject; nay, such as no prince or

6 Lang, 140. 
potentate on earth could at that time pretend to."7 Handel must have found his employment with the Duke to be enjoyable, or at least advantageous, for he stayed two years. He didn't leave until February 1719, when he traveled to Dusseldorf, Halle, and Dresden to hire singers for the proposed Royal Academy of Musick.

\section{MUSIC AND MUSICIANS AT CANNONS}

James Brydges was one of the foremost patrons of the arts and spared no expense in redecorating his mansion at Cannons with the most lavish art work and architectural design possible. He built his musical establishment with the same attention to excellence. The Duke's musical reputation was well known by the time Handel came to Cannons. Although there were only a small number of musicians, their musical skills were excellent.

Brydges used music at Cannons in many ways similar to its use by royalty. There was special music for meals, daily music lessons, music for special occasions, and music for chapel services. The musicians who lived at Cannons were hired for their musical talent, although they occasionally held other household positions. Handel is believed to have rehearsed and directed these musicians, composed music for

7 Ibid. 141. 
rehearsed and directed these musicians, composed music for them, and quite possibly, to have given music instruction to Brydges' household.

While at Cannons, Handel's choral compositions included eleven anthems, one Te Deum, a masque called Acis and Galatea, and the oratorio, Esther. His instrumental works were a sonata for two violins, oboe and bass (Sonata in G minor), and an unknown number of overtures to be played hefore lessons. He may also have written and/or revised some keyboard suites and fugues.

The musical forces when Handel first came to Cannons only allowed for three-part music, but later increased to allow four parts. The first musicians were mostly professionals who were active in the London theater and who provided no extra-musical services such as household servant duties. There were approximately seven instrumentalists and three singers, one to a part. Within a short time, this had increased to thirteen instrumentalists and nine singers. Many of these also served as household servants. The treble parts were sung by young boys who were trained in musicianship and singing, but received no salary, or at least very little salary, for their singing. They most often appear in wage records as pages, ushers, valets, and grooms.

From extant Receipt Books for Wages, it is possible to identify the singers at Cannons. The Receipt Books were 
documented in Quarters as dictated by law. Rents were paid, contracts due, wages paid, and business regulated by the English Quarters. The English Quarters were:

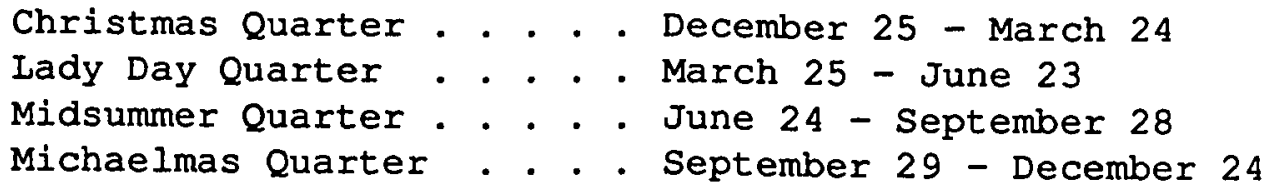

The Cannon Receipt Books give a detailed account of the musicians, their wages, and their dates of employment. Beek's dissertation presents an exhaustive study of the musical establishment at Cannons and includes biographies of the musicians whose names appear in the receipt books.8 He is believed to be the only author to have researched and documented the musicians employed at Cannons.

BELL, THOMAS (D. 1743). Tenor/Countertenor. Bell served at Cannons. from June 1, 1720 until (?) January, 1721. He held an appointment at Westminster Abbey and the Chapel Royal. He is listed in autographs as alto and tenor soloist in Anthem VI-B, As Pants the Hart, alto soloist in Anthem VID, As Pants the Hart, and bass soloist in the Coronation Anthems of 1727 .

8 Graydon Fisher Beeks, Jr., The Chandes Anthems and Te Deum of George Frideric Handel, Ph.D. dissertation, (University of California, Berkeley, 1981), Chapter 1. 
BLACKLEY (BLAKELY), JAMES. Tenor. Blackley was on the Cannons Roster from Lady Day Quarter, 1717, until Christmas Quarter, 1719. He was a well-known soloist in the London theater and is believed to have had an extremely high, agile voice. He received a very large salary from the Duke and may have tutored the Duke's sons. He was the tenor soloist for the first eight anthems, and tenor I for the other three, as well as the Te Deum.

GETHIN (GETTING, GETHWIN), THOMAS. (baptized Brjdewell chapel, December 30, 1696. d. after 1732). Tenor/Countertenor. Gethin served at Cannons from April 29, 1720 to June 24, 1720, and again for the Michaelmas Quarter, 1720, and Christmas Quarter, 1721. As a boy, he was a chorister at the Chapel Royal. As an adult, he sang at both the Chapel Royal and Westminster Abbey. He was also a soloist at Drury Lane Theatre. He is listed in autographs as soloist for Chapel Royal Anthems V-B, I Will Magnify Thee, VI-B, As Pants the Hart, and the A-Major Te Deum.

GLANVILLE, EDWARD. ?Bass. Glanville appears on the Christmas Quarter Roster, 1717. Although there is no indication on the Roster of his voice part, other documentation indicates he was a bass.

HARRISON, JOSH. ?TEnor. Harrison appeared on the Roster from Lady Day Quarter, 1718 to Michaelmas Quarter, 1718. 
MORPHOW. Contralto. Morphow's name does not appear on early receipt records although references are made to him in other record books. He was possibly an older boy who sang alto and may have been a treble at one time. This would explain his name not appearing in wage records.

PIERSON. Treble. Pierson does not appear on a Roster until New Year's Day, 1721, but references to him indicate he may have been a music apprentice. He was probably one of three trebles in residence.

PERRY, WILIIAM. (b. c.1695. d. November 24, 1777). Bass. Perry was on the Cannons roster from Christmas Quarter, 1718, until New Year's Day 1720/21. He was a chorister of the Chapel Royal as a child. As an adult, he was also a member of the Chapel Royal choir.

ROGERS (RIGS), AMOS. Treble. Rogers served the Duke's household as a singer, page to the Duchess, and possibly as a groom. He was a paid singer only in the Christmas Quarter, 1720 .

ROGERS (RODGERS), WILIIAM. Tenor. Rogers may have been a treble when Handel was at Cannons. He was in residence as an usher, a page, and a groom, with a small salary. After his voice changed, he sang tenor and appeared on the wage records, so it may be assumed he had been trained to sing as a treble. 
ROW (ROWE), FRANCIS. (b. ?1694. d. 1755). Tenor/ Countertenor. Row does not appear on wage records at Cannons, but is noted as a soloist in autographs. This may indicate he was an adjunct musician for the Duke. He sang at Westminster Abbey, St. Paul's, and the Chapel Royal. He was the tenor soloist for Acis and Galatea, the Chandos Te Deum, Anthem VIII, the Ultrecht Te Deum and Iubilate, and the oratorio, Esther.

VANBRUgh (VANBRUghe, GHENTBRUGHE), GEORGE. Bass. Vanbrugh came to Cannons before the Christmas Quarter, 1719 and stayed until after New Year's, 1720/21. He was a singer and gave numerous concerts. He was also a composer and published several well-accepted books of music.

From Handel's arrival at Cannons until his departure, Wage Receipt Books document the increase in the musical forces. The size of the Chandos choir and the special nature of the composition affect present-day performance practice of the anthems. The Chandos Anthems were written for specific voices, and a knowledge of the musicians gives a better understanding of performance considerations when performing one of the anthems. 


\section{Chapter 3}

OVERVIEW OF THE CHANDOS ANTHEMS

I. PURPOSE

The Chandos Anthems were written for the private chapel services of the Duke of Chandos. It might be assumed that these anthems were written as deeply-felt expressions of religious faith for the religious nature of an Anglican worship service. Such was not the circumstance, however. The Duke was very proud of his resident composer and musicians, and used his chapel services as a stage upon which to highlight his musicians. It should be noted that the Anglican Church had become a political institution, almost secular in nature. Iang said, the Church of England had "abandoned the mysteries of religion, and its real raison d'etre was a form of materialism couched in biblical words."1 Under these circumstances, the chapel services at Cannons may not have been an altogether unique style of worship. The Chandos Anthems were written to accommodate this venue.

Dean noted, "Handel was by training and temperament a composer for the theater which monopolized his attention

1 Lang, 211. 
throughout his life. . . ."2 He has been criticized by several authors for composing his church music for practical and ceremonial purposes, rather than as an expression of personal beliefs. Lam said:

Throughout his life, Handel was an occasional composer, always writing for some practical purpose and adapting his style to circumstances with a magnificent unawareness of the later belief that an artist should be moved only by his own inner conflicts. 3

In the Chandos Anthems, Handel composed quality music, with a religious text, that suited the ceremonial purpose of the Duke's chapel service.

Handel's compositions were not religious pieces first and musical expressions second. Rather, they were musical compositions designed for situations that were best suited to expression through means connected with religious text. 4

Grout called the anthems "masterpieces of Anglican Baroque church music."5

2 Dean, 85

3 Lam, 156.

4 Elwyn A. Wienandt, Cheral Music of the church, (New York: DaCapo Press, 1980. Reprint. New York: The Free
Press, 1965), 168-169.

5 Donald Jay Grout, A Histery of Western Music, Third Edition, (New York: W. W. Norton \& Company, 1980), 443. 
The texts of all but one of the Chandos Anthems were taken from the Book of common Prayer. Rather than setting an entire Psalm, Handel selected lines from several Psalms. This practice was usually reserved for special occasion or ceremonial music. It was also a practice which makes the Chandos Anthems more like oratorio than canticle settings. The general air of rejoicing of the Psalms and the use of selected lines emphasize the ceremonial aspect of the chandos Anthems.

\section{CHRONOLJGY AND NUMBERING}

The chronology and numbering of the Chandos Anthems are problematic for researchers. The anthems were never published during Handel's lifetime and circulated only in manuscripts which were often incomplete or incorrect. The scribes who copied the anthems combined movements from various anthems and Te Deums, from both the Chandos Anthems and Chapel Royal works. This made it difficult later to identify the movements and the order of the movements in each of the Chandos Anthems. Creating further difficulty was Handel's practice of reusing and reworking music from the anthems, Te Deums, and Chapel Royal works. Since he did not date these works, the movements were often combined incorrectly. 
Several attempts were made to establish the chronology and content of the anthems. In 1783, Birchall and Beardmore of Iondon stated their intention to publish a complete set of the Chandos Anthems, but ultimately published only one anthem. The rival firm of Wright and wilkinson published ten of the anthems in 1784, but the set was incomplete and incorrect. From 1789-1797, Samuel Arnold compiled the anthems as a set in The Works of Handel in score, but again, the various versions were mixed and the set was incorrect.

Friedrich Chrysander edited the anthems for volumes 3436 of the German Handel Society's George Friedrich Händels Werke (1871-1872). He included all the anthems and Te Deums in their various forms, but did not give clear indication of the authentic Chandos Anthems. His system of numbering is the most widely used, but does not place the anthems chronologically. An awareness of the different versions and the different numbering systems is necessary when researching the anthems, since authors and publishers occasionally refer to anthems by one of the numbering systems other than Chrysander's. Table 1 illustrates the various versions. 
Table 1. Anthems As Published 6

\begin{tabular}{l}
\hline Title Chrysander Arnold Wright \\
\hline
\end{tabular}

\section{Chandos Anthems}

O be joyfull in the Lord In the Lord put I my trust Have mercy upon me, O God o sing unto the Lord I will magnifie thee As pants the hart My song shall be allway o come, let us sing unto the Lord O praise the Lord with one consent The Lord is my light Let God arise

$\begin{array}{lrr}\text { I } & -- & -- \\ \text { II } & 10 & 5 \\ \text { III } & 4 & 7 \\ \text { IV } & 6 & 3 \\ \text { V-A } & 1 & 4 \\ \text { VI-A } & 8 & 9 \\ \text { VII } & 7 & 8 \\ \text { VIII } & 5 & 1 \\ \text { IX } & 11 & 6 \\ \text { X } & 9 & 3 \\ \text { XI-A } & 3 & --\end{array}$

Chapel Royal Anthems

O sing unto the Lord I will magnifie Thee As pants the hart As pants the hart As pants the hart Let God arise
IV $-A$

$\mathrm{V}-\mathrm{B}$

$V I-B$

$V I-C$

VI-D

$X I-B$

$\begin{array}{ll}-- & -- \\ -- & -- \\ -- & -- \\ -- & -- \\ -- & -- \\ 2 & 10\end{array}$

Beeks' dissertation suggests a chronology for the anthems "based on the evidence of early manuscript copies, external references, and stylistic traits."7 Most musicologists agree that the anthems were most likely written in

6 Beeks, 7-8.

7 Ibid. 325. 
pairs. Beeks pairs all but three of the anthems: VIII, IX, and $x$. These three anthems and the chandos Te Deum, he believes, were written either separately or as a set of four. He has proposed the tentative chronology found in Table 2.

Table 2. Proposed Tentative Chronology 8

\begin{tabular}{|c|c|}
\hline $\begin{array}{l}\text { Anthem II } \\
\text { Anthem V-A }\end{array}$ & before 25 September 1717 \\
\hline $\begin{array}{l}\text { Anthem I } \\
\text { Anthem III }\end{array}$ & before 25 September 1717 \\
\hline $\begin{array}{l}\text { Anthem IV } \\
\text { Anthem VI-A }\end{array}$ & shortly after 25 September 1717 \\
\hline $\begin{array}{l}\text { Anthem XI-A } \\
\text { Anthem VII }\end{array}$ & perhaps before the end of 1717 \\
\hline $\begin{array}{l}\text { Te Deum } \\
\text { Anthem IX } \\
\text { Anthem VIII } \\
\text { Anthem X }\end{array}$ & around May/June 1718 \\
\hline
\end{tabular}

III. DESCRIPTION OF THE ANTHEMS

Winton Dean described the style of the Chandos Anthems as "eclectic: the Purcellian anthem, the Italian sonata (in the instrumental introductions), the ringing counterpoint of

8 Ibid. 333. 
Venetian church music, the German chorale. . ."9 Basil Iam said the Chandos Anthems remain an "isolated group, the only representatives of the Protestant cantata in Handel's output. - . "10 They represent the beginning of the oratorio style of composition.

Each anthem is a distinct unity with an overall harmonic scheme. With the exception of Anthem IX, all the anthems begin with an introductory sonata which establishes the tonality. The anthems continue with alternating solo and chorus sections, with logical key relationships between movements. The conclusion of each anthem is a final chorus in the tonic key. The overall design of the anthems appears in the Appendix.

Following is a brief description of each of the anthems.

ANTHEM I - $O$ BE JOYFUL IN THE LORD

$\begin{array}{ccccccc}\text { Sonata } & \text { Solo/Chorus } & \text { Chorus } & \text { Duet } & \text { Chorus } & \text { Duet } & \text { Chorus } \\ \text { D } & \text { D } & \text { D } & \text { Am } & \text { F } & \text { Gm } & \text { D }\end{array}$

Anthem I is almost identical to the Utrecht Jubilate of 1713. Handel reduced the chorus from four and five parts to

9 Winton Dean, The New Grove Handel, (New York: W. W. Norton \& Company, 1983. First published in The New Grove Dictionary of Music and Musicians, edited by Stanley Sadie, 1980), 25.

10 Lam, 156. 
three parts, and reduced the orchestra to strings (without viola) and two oboes. He also added an instrumental introduction. The text is from Psalm 100, verses 1-4, plus the Gleria Patri. "This is the only one of the Chandos Anthems which is properly a Canticle [sic] and not an anthem."11 The setting of the Psalm text as a unit, without selections from other Psalms, and the inclusion of the Gloria Ratri, identify the anthem as a canticle.

ANTHEM II - IN THE LORD PUT I MY TRUST $\begin{array}{cccccccc}\text { Sonata } & \text { Chorus } & \text { Solo } & \text { Chorus } & \text { Solo } & \text { Chorus } & \text { Solo } & \text { Chorus } \\ \text { Dm } & \text { Dm } & F & B^{b} & G m & D & \text { Dm } & \text { Dm }\end{array}$

Anthem II is not considered very remarkable overall, although there are some fugues which are very well written. Lang described the tone of this anthem as "prevailingly intimate, leaning toward the pastoral."12 The text was taken from Psalms 9, 11, 12, and 13.

\section{ANTHEM III - HAVE MERCY UPON ME}

$\begin{array}{ccccccc}\text { Sonata } & \text { Chorus } & \text { Duet } & \text { Solo } & \text { Chorus } & \text { Solo } & \text { Chorus } \\ \mathrm{Cm} & \mathrm{Cm} & \mathrm{E}^{\mathrm{b}} & \mathrm{Fm} & \mathrm{F} & \mathrm{Cm} & \mathrm{Cm}\end{array}$

Most of the vocal movements in Anthem III were borrowed from the Utrecht Te Deum of 1713. It is the only anthem

11 Beeks, 382 .

12 Lang, 224. 
whose theme is primarily one of penitence. The text is taken from Psalm 51, verses $1-4,8$, and 10-13.

ANTHEM IV - O SING UNTO THE LORD A NEW SONG

Sonata Solo/Chorus Chorus Solo Duet Chorus Chorus

$\begin{array}{llllllll}F & F & F & D m & B^{b} & G m & F\end{array}$

Anthem IV is a transcription of an earlier Chapel Royal anthem, although extensively modified. While the other threevoice anthems were written many times in a four-voice style, Anthem IV is more trio-like. The tone of the anthem is festive in its proclamation of praise. The text was taken from Psalm 96, verses $1,3-4,9$, and 11 .

ANTHEM $V-A$ - I WILL MAGNIFY THEE

Sonata Chorus Solo Chorus Solo Solo solo Chorus
A
A
$\mathrm{E}$
A
D $\quad F^{\#}$ A
A

I will magnify Thee exists in two versions, with $V-A$ being the Chandos version. It is related to the $A$ major trio sonata (Op. 5, No. 1), with two of the movements used as the introduction, and other movements used as vocal pieces. It is not noteworthy. The text is from Psalm 145.

ANTHEM VI-A - AS PANTS THE HART

$\begin{array}{ccccccc}\text { Sonata } & \text { Chorus } & \text { Solo } & \text { Solo } & \text { Chorus } & \text { Duet } & \text { Chorus } \\ \text { Em } & \text { Em } & \text { Am } & \text { Em } & G & \text { Bm } & \text { Em }\end{array}$ 
Four versions exist of As pants the hart; VI-A is the Chandos version. The anthem begins with a feeling of melancholy and ends with a feeling of joyousness. The text is from Psalm 42, verses 1 and 3-7 (altered).

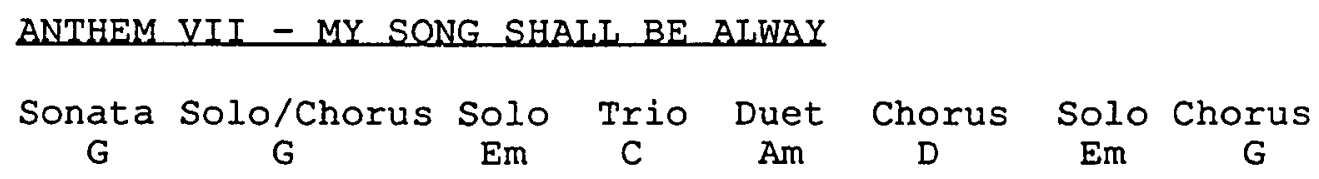

Basil Lam said, "The seventh anthem, My song shall be alway, contains nothing of special value or interest."13 All but one movement is borrowed from earlier works. The text is Psalm 89, verses 1, 5-9, 12, 15-16, and 18 part 1.

VIII - $O$ COME LET US SING UNTO THE LORD

Sonata Chorus Solo Chorus Solo/Chorus Solo Solo Solo Chorus

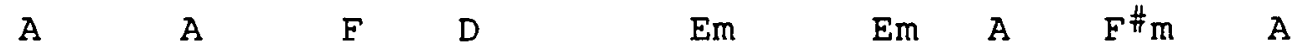

Lang called 0 come let us sing unto the Lord one of the finest of the Chandos Anthems. "It is a piece of general rejoicing, one of the real ceremonial works, as elaborate, powerful, and splendid as any of the great oratorios."14 Anthem VIII is unique in several aspects. It is the only anthem to use two recorders, is one of the longest of the anthems, and is one of only two anthems to use a complex

13 Lam, 170-171.

14 Lang, 225. 
variety of texts. The texts are Psalm 95, verses 1-3, and 67; Psalm 96, verse 6 and verse 10 (part 1, altered); Psalm 99, verse 9; Psalm 97, verse 10 (part 2); Psalm 103, verse 11 (altered); Psalm 97, verses 11-12 (part 1).

ANTHEM IX - 0 PRAISE THE LORD WITH ONE CONSENT

$\begin{array}{ccccccc}\text { Chorus } & \text { Solo solo solo } & \text { Chorus } & \text { Solo } & \text { Chorus } \\ \mathrm{E}^{\mathrm{b}} & \mathrm{Cm} & \mathrm{Gm} & \mathrm{B}^{\mathrm{b}} & \mathrm{E}^{\mathrm{b}} & \mathrm{Gm} & \mathrm{E}^{\mathrm{b}}\end{array}$

Anthem IX is the only anthem with no instrumental sonata, and the only anthem with a bass solo. Authors do not seem to agree on its quality. Lam called this anthem distinguished in its choruses, although too long. 15 Beeks said it was one of the better anthems for "originality of musical ideas, consistently high quality of invention and creative scoring."16 Lang found it full of "rhetorical pathos."17 It is the only anthem to have a text taken completely from a source other than The Book of common Rraver. The text is from Tate \& Brady, Psalm 135, verses 1-3 and 5; Psalm 117, verses 1-2; Psalm 148, verses 1-2.
15 Lam, 173.
16 Beeks, 664 .
17 Lang, 226. 
ANTHEM $X$ - THE IORD IS MY IIGHT

$\begin{array}{ccccccccc}\text { Sonata Solo } & \text { Chorus } & \text { Solo } & \text { Chorus } & \text { Chorus } & \text { Solo } & \text { Solo } & \text { Chorus } \\ \mathrm{Gm} & \mathrm{Gm} & \mathrm{B}^{\mathrm{b}} & \mathrm{E}^{\mathrm{b}} & \mathrm{Cm} & \mathrm{B}^{\mathrm{b}} & \mathrm{E}^{\mathrm{b}} & \mathrm{Cm} & \mathrm{Gm}\end{array}$

The Lord is my light is one of the better anthems. It is almost militaristic in feeling and is one of the more ceremonial works. Its text is also one of the most complex. It was taken from Psalm 27, verses 1, 3, 4, and 7; Psalm 18, verses 31, 7, and 14 (altered), Psalm 20, verse 8 (partial), Psalm 34, verse 3; Psalm 28, verse 8; Psalm 39, verse 4, combined with Psalm 29, verse 9; Psalm 30, verse 4; and Psalm 45 , verse 18 .

ANTHEM XI-A - LET GOD ARISE

$\begin{array}{cccccc}\text { Sonata } & \text { Chorus } & \text { Solo } & \text { Solo } & \text { Chorus } & \text { Chorus } \\ \mathrm{B}^{\mathrm{b}} & \mathrm{B}^{\mathrm{b}} & \mathrm{Gm} & \mathrm{F} & \mathrm{Dm} & \mathrm{B}^{\mathrm{b}}\end{array}$

Anthem XI-A was the first anthem to be written for more than three voices. It is the least interesting of the fourvoice anthems, and is written in a somewhat grand manner. It was the first anthem to use part of a text in a Psalm some distance from the main Psalm text. The text is Psalm 68, verses 1-4 (part 1), verse 19 (part 1), verse 35 (last line), and Psalm 76, verse 6 (altered). 


\section{Chapter 4}

ANALYSIS OF SOLOS

The Chandos Anthems include almost as many solos as choruses. The alternation of solos, soli sections, and choruses show Handel's care in the overall scheme of an anthem. He was not, however, as judicious in assigning the solos. In the eleven Chandos Anthems, there are a total of thirty-seven choruses and thirty solos.1 of the thirty solos, eighteen are for tenor and ten for canto. The only alto solo is designated alto or tenor, and the one remaining solo is for bass.

This unequal designation of solos necessitated some analysis of solos in other works to determine whether discernible patterns exist in Handel's writing for solos. The Chapel Royal works and the oratorios, Deborah, Balshazzar, and Messiab are works which bear a relationship to the Chandos Anthems in their style and subject matter, and are the additional works chosen for analysis.

The analysis of the solos includes an examination of musical characteristics where patterns might appear which could be associated with a specific voice. Areas of analysis

1 Appendix B lists the Chandos Anthems and Chapel Royal Anthems by title and number, the solos in the anthems, and the voicing of the solos. 
include instrumentation, style, text subjects, and position in work. The final analysis is an examination of solos in the anthems which were reused in other works, or were transcriptions from other works, which were assigned to a different voice.

\section{INSTRUMENTATION}

The Chandos Anthems are scored for violin I and II, oboe (sometimes I and II), bass, and organ. In one anthem solo, there are parts for flute I and II. Each of these instruments are charted in association with their use in the anthem solos.

It is necessary for the alto and bass solo to examine works other than the Chandos Anthems since these two voices were seldom used for solos in Chandos works. The instrumentation for both the Chandos Anthems and Chapel Royal works is shown in Table No. 3 (p. 34).

Several conclusions can be drawn from this analysis. First, Handel showed no preference for instrumentation in soprano and tenor solos. Second, he scored the viola in alto solos more often than in soprano and tenor solos. It is difficult, however, to establish a clear preference, given the limited use of the viola.

One clear pattern emerges in connection with bass solos. In all the works examined, Handel scored an oboe on 
a bass solo only one time. Works examined, in addition to the Chandos Anthems and Chapel Royal works, were the oratorios, Deborah, Belshazzar, and Messiah. The one solo in which Handel scored an oboe is "Like as the smoke vanisheth" in Anthem XI-B (See Example 5, p. 39). This solo has a very high tessitura and calls for vocal agility with four-measure, sixteenth-note roulades on the word "drive." These two characteristics may indicate the appropriateness of an oboe, which would not normally be associated with a bass solo. The analysis of these works alone seems to indicate a clear preference for omission of an oboe part on most bass solos. This is not always the circumstance in some of Handel's other works, however.

Table 3. Instrumentation of Solos in the Chandos Anthems and Chapel Royal Works.

\begin{tabular}{|c|c|c|c|c|c|c|c|}
\hline REF.\# & VOICE & FLUTE & OBOE & VIOLIN & VIOLA & CONTINUO & BASSOON \\
\hline & & & & & & & \\
\hline$I$ & Tenor & & $\mathrm{X}$ & $\mathrm{I} \&$ II & & $\mathrm{X}$ & \\
\hline II & Tenor & & $\mathrm{X}$ & $\mathrm{I} \&$ II & & $\mathrm{X}$ & \\
\hline & Tenor & & $\mathrm{X}$ & $\mathrm{I} \&$ II & & $\mathrm{X}$ & \\
\hline III & Tenor & & & $\mathrm{I} \&$ II & & $\mathrm{X}$ & \\
\hline & Canto & $\mathrm{X}$ & $\mathrm{I} \&$ II & & $\mathrm{X}$ & \\
\hline IV & Canto & & $\mathrm{X}$ & & & $\mathrm{X}$ & \\
\hline $\mathrm{V}-\mathrm{A}$ & Tenor & & & $\mathrm{I} \&$ II & & $\mathrm{X}$ & \\
\hline & Canto & & & $\mathrm{I} \&$ II & & $\mathrm{X}$ & \\
\hline & Tenor & & $\mathrm{X}$ & $\mathrm{I} \&$ II & & $\mathrm{X}$ & \\
\hline & Tenor & & & $\mathrm{I} \&$ II & & $\mathrm{X}$ & \\
\hline
\end{tabular}


Table 3. (continued)

\begin{tabular}{|c|c|c|c|c|c|c|c|}
\hline REF.\# & VOICE & FLUTE & OBOE & VIOLIN & VIOLA & CONTINUO & BASSOON \\
\hline \multirow{3}{*}{$\mathrm{V}-\mathrm{B}$} & Alto & & $\mathrm{x}$ & $I \& I I$ & $x$ & $x$ & \\
\hline & Bass & & & & & $\mathrm{x}$ & \\
\hline & Alto & & $x$ & $I \& I I$ & & $\mathrm{x}$ & \\
\hline \multirow[t]{2}{*}{ VI-A } & Canto & & $\mathrm{x}$ & $I \& I I$ & & $\mathrm{x}$ & $\mathrm{x}$ \\
\hline & Tenor & & $\mathrm{x}$ & $I \& I I$ & & $\mathrm{x}$ & $\mathrm{x}$ \\
\hline$V I-B$ & Alto & & $x$ & $I \& I I$ & $\mathrm{x}$ & $x$ & $x$ \\
\hline $\mathrm{VI}-\mathrm{C}$ & Alto & & & & & $\mathrm{x}$ & \\
\hline \multirow[t]{3}{*}{ VII } & Canto & & $\mathrm{x}$ & $I \& I I$ & & $x$ & \\
\hline & Tenor & & $\mathrm{x}$ & I & & $\mathrm{x}$ & \\
\hline & Canto & & $\mathrm{x}$ & $I \& I I$ & & $x$ & \\
\hline \multirow[t]{5}{*}{ VIII } & Tenor & $I \& I I$ & & $I \& I I$ & & $\mathrm{x}$ & \\
\hline & Tenor & & & & & $x$ & \\
\hline & Canto & & & $I \& I I$ & & (X) & \\
\hline & Tenor & & $x$ & $I \& I I$ & & $\mathrm{x}$ & \\
\hline & Tenor & & & $I \& I I$ & & $x$ & \\
\hline \multirow[t]{4}{*}{ IX } & Tenor & & $\mathbf{x}$ & I & & $x$ & . \\
\hline & Tenor & & $\mathrm{x}$ & $I \& I I$ & & & \\
\hline & Bass & & & $I \& I I$ & & $\mathrm{x}$ & \\
\hline & Canto & & $x$ & $I \& I I$ & & & \\
\hline \multirow[t]{3}{*}{$\mathrm{x}$} & Tenor & & $x$ & $I \& I I$ & & $\mathrm{x}$ & \\
\hline & Tenor & $I \& I I$ & & $I \& I I$ & & $x$ & \\
\hline & Canto & & $x$ & $I \& I I$ & & $x$ & \\
\hline \multirow[t]{2}{*}{$X I-A$} & Tenor & & $\mathrm{x}$ & $I \& I I$ & & $\mathrm{x}$ & $\mathrm{x}$ \\
\hline & Canto & & $x$ & $I \& I I$ & & $\mathrm{x}$ & $\mathrm{x}$ \\
\hline$X I-B$ & Bass & & $\mathrm{x}$ & $I \& I I$ & $\mathrm{x}$ & $x$ & \\
\hline \multirow[t]{4}{*}{$X I I$} & Alto & & & & & $x$ & \\
\hline & Bass & & & $I \& I I$ & & $\mathrm{x}$ & \\
\hline & Alto & & & $I \notin I I$ & $x$ & $\mathrm{x}$ & \\
\hline & Bass & & & $I \& I I$ & & $\mathrm{x}$ & \\
\hline \multirow[t]{5}{*}{ XIII } & Alto & & $I \& I I$ & & & $x$ & $\mathrm{x}$ \\
\hline & Bass & & & & & $x$ & $x$ \\
\hline & Canto & $I \& I I$ & & $I \& I I$ & & & \\
\hline & Tenor & & $I \& I I$ & $I \& I I$ & & $\mathrm{x}$ & \\
\hline & Bass & & & $I \& I I$ & & & \\
\hline \multirow[t]{2}{*}{ XIV } & Canto & & & $I \& I I$ & & $\mathrm{x}$ & \\
\hline & Bass & & & & \multicolumn{3}{|c|}{$\mathrm{x} /$ cello solo } \\
\hline XV & Bass & & & $I \& I I$ & & $\mathrm{x}$ & \\
\hline XVI & Tenor & & & $I \& I I$ & & $x$ & \\
\hline IV $-\mathrm{A}$ & Bass & & & & & $x$ & \\
\hline
\end{tabular}


In addition to charting the instrumentation on each solo, an analysis was made of the instrumental counterpoint in relation to the solo voice to determine whether a pattern exists for specific voices. It was concluded that instruments were not scored differently for canto, tenor, or alto. Examples 1, 2, and 3 show typical instrumentation for canto, tenor, and alto solos. A comparison of the three solos shows the similar manner in which the imitation and counterpoint between the instruments and voices is treated.

Example 1. Oboe imitation of canto vocal figure in canto solo, "My song shall be alway" from Chandos Anthem VII, My song shall be alway (H.G. v. 35, p. 7).
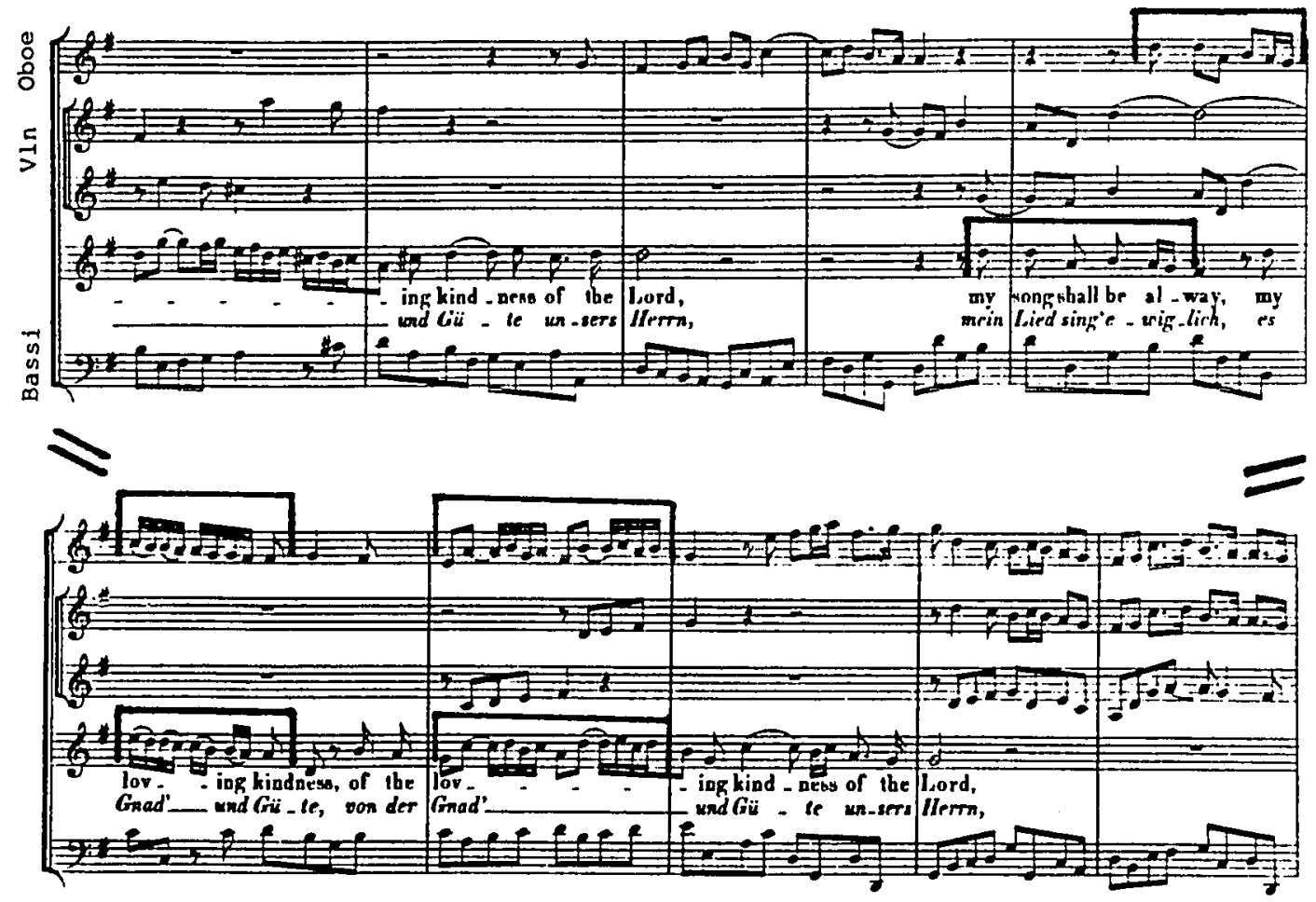
Example 2. Oboe imitation of tenor vocal figure in tenor Solo, "The Lord preserveth" from Chandos Anthem VIII, e come let us sing unte the ford (H.G. v. 35, p. 85).
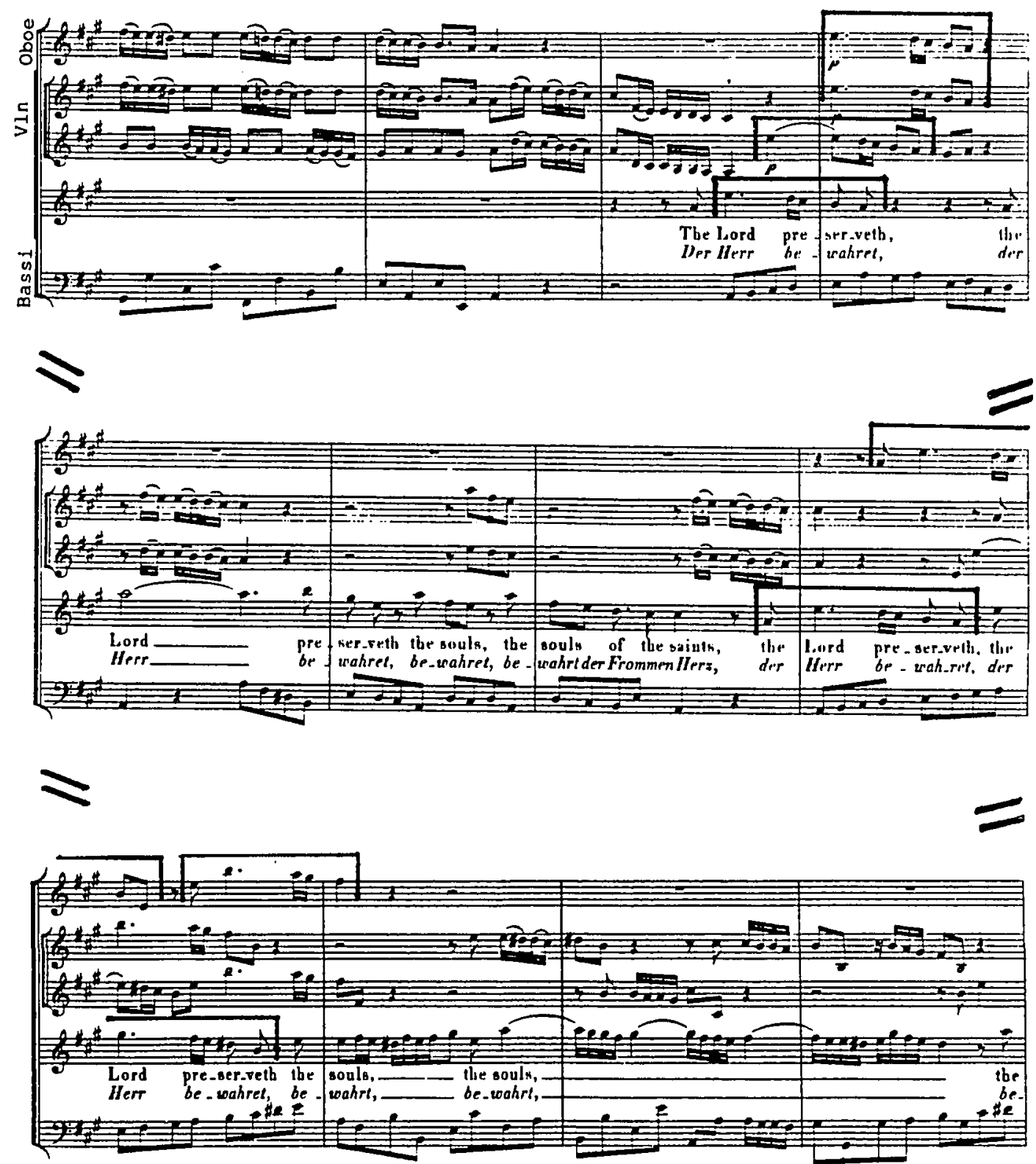
Example 3. Alto vocal imitation of oboe figure in alto solo, "I will magnify Thee," from Chapel Royal Anthem V-B, I will magnify thee (H.G. v. 34, p. 171).

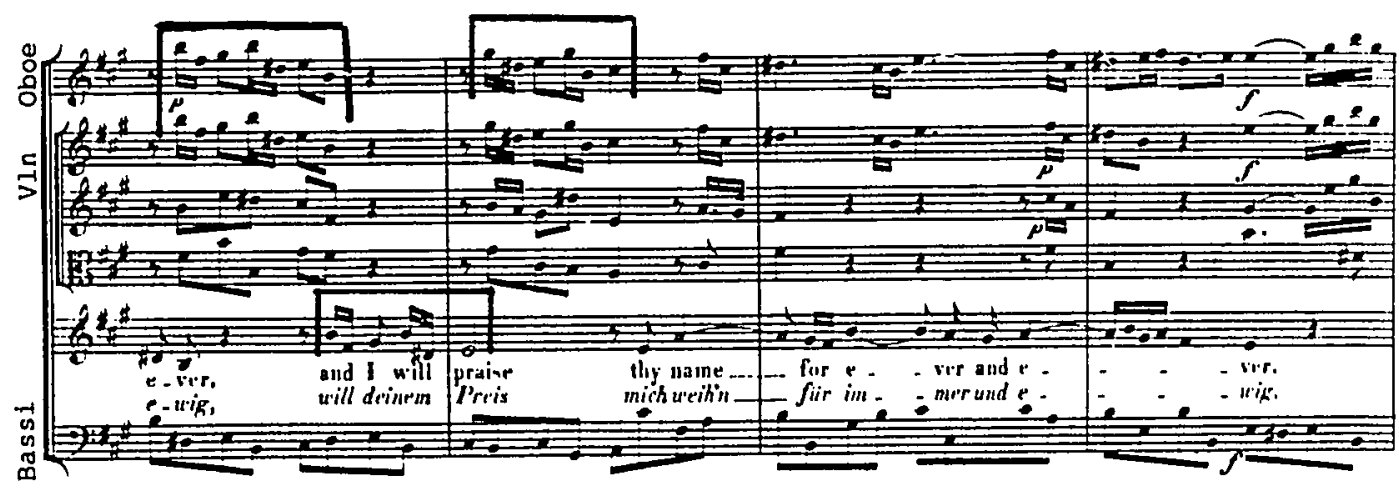

The bass voice again seems to have characteristics not found in other voices. Although the treble instruments, with the exception of the oboe, do not appear to be written significantly differently (See Examples 4 and 5), the continuo in bass solos is handled differently. The bass voice is the only voice to be doubled by the continuo in solos, and this occurs very consistently. Example 4 is typical of many bass solos where the continuo doubles the voice. It is very rare for other solo voices to be doubled by any instrument, and they are never doubled by the continuo.

When the continuo is not doubling the voice in the bass solo, it always stays below the voice and is a complement to the vocal line. This can be seen in Example 5 . 
Example 4. Continuo doubling of bass vocal line in bass solo, "That God is great" from Chandos Anthem IX, Q praise the Lord with one consent (H.G. v. 35, p. 121).

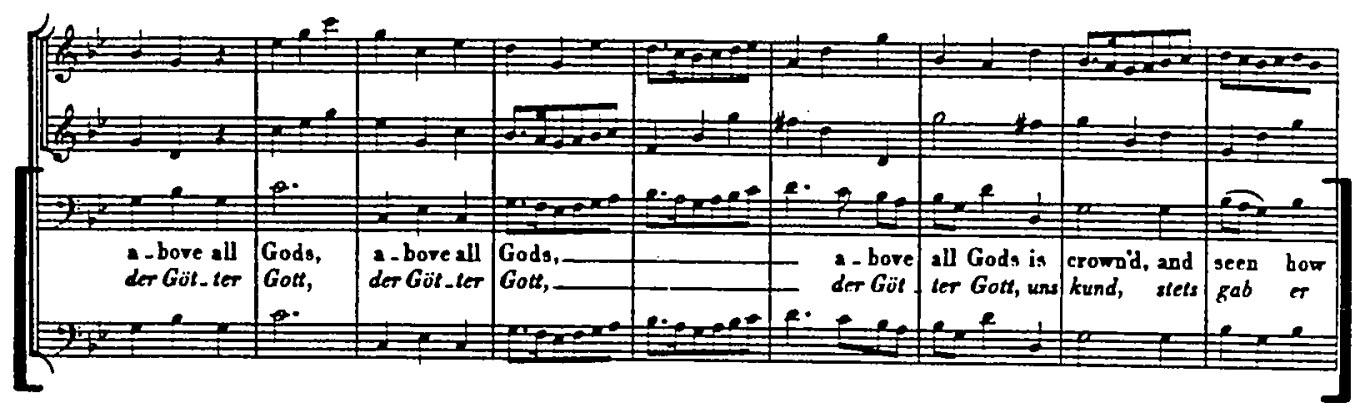

Example 5. Comparison of the continuo counterpoint and bass vocal line in bass solo, "Like as the smoke vanisheth" from Chapel Royal Anthem XI-B, Let God arise (H.G. v. 35, p. 277).

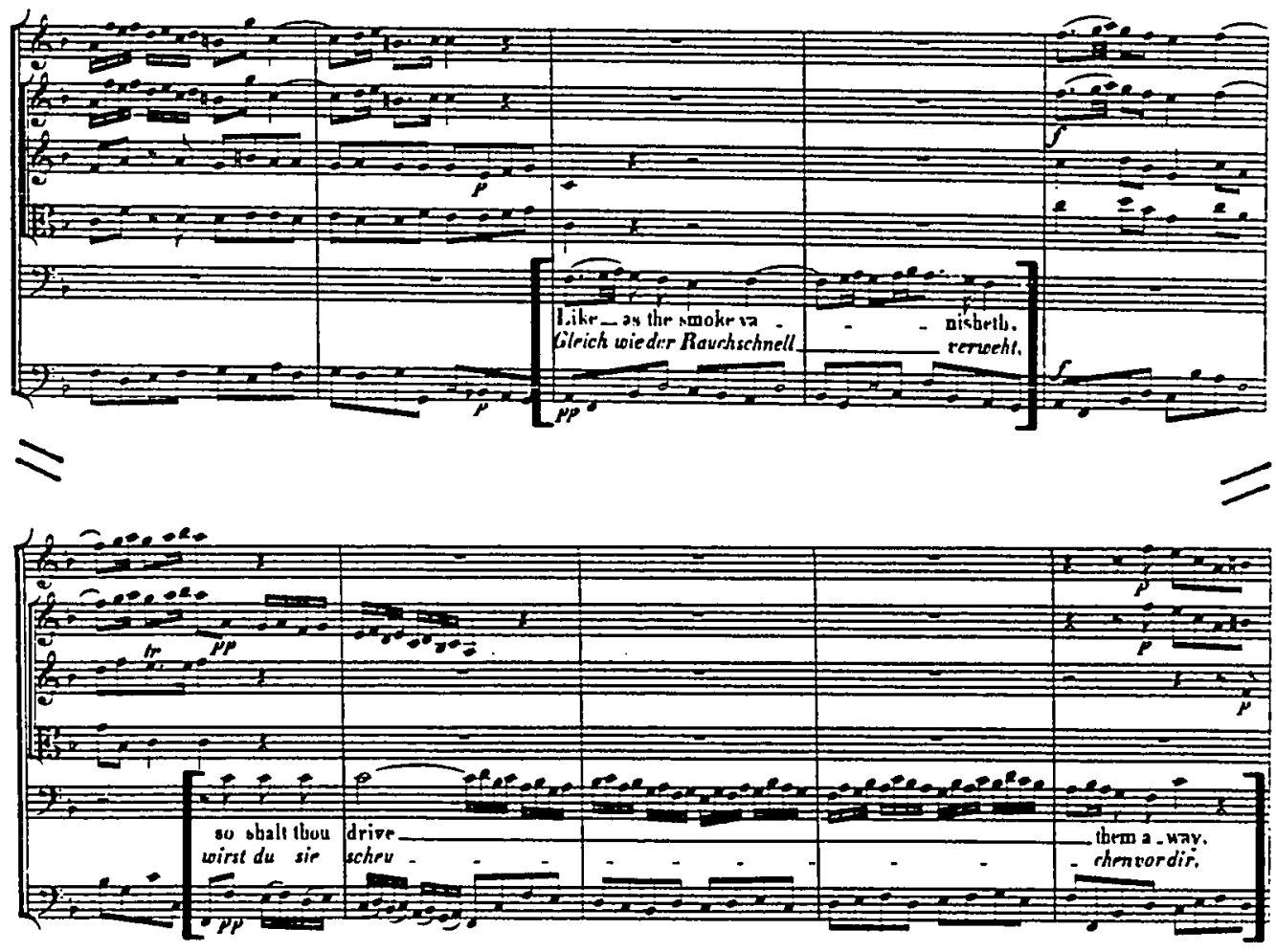


II. STYLE

Formal aspects of the solos were analyzed, including harmonic and melodic content. Some significant patterns emerged in relation to the Chandos Anthems as a whole, but not in relation to a specific voice. Most of the solos are in the form of a modified da capo aria. Handel set the texts often in a form which appears to be a da capo aria, but contains modification in melodic content, modulation, and motivic development. The texts are usually two lines of contrasting or non-contrasting ideas, sentiments, or emotions.

Almost all solos have some unifying element which appears throughout the solo. This is often a motive which is presented in the opening ritornello and appears throughout the solo in vocal and instrumental parts. Example 6 illustrates a unifying motive which is identified as it appears in the opening ritornello and in the solo voice. 
Example 6. Unifying motive in vocal and instrumental lines in tenor solo, "God is a constant sure defense" from Chandos Anthem II, In the Iord put I my trust (H.G. v.34, p. 51-52).
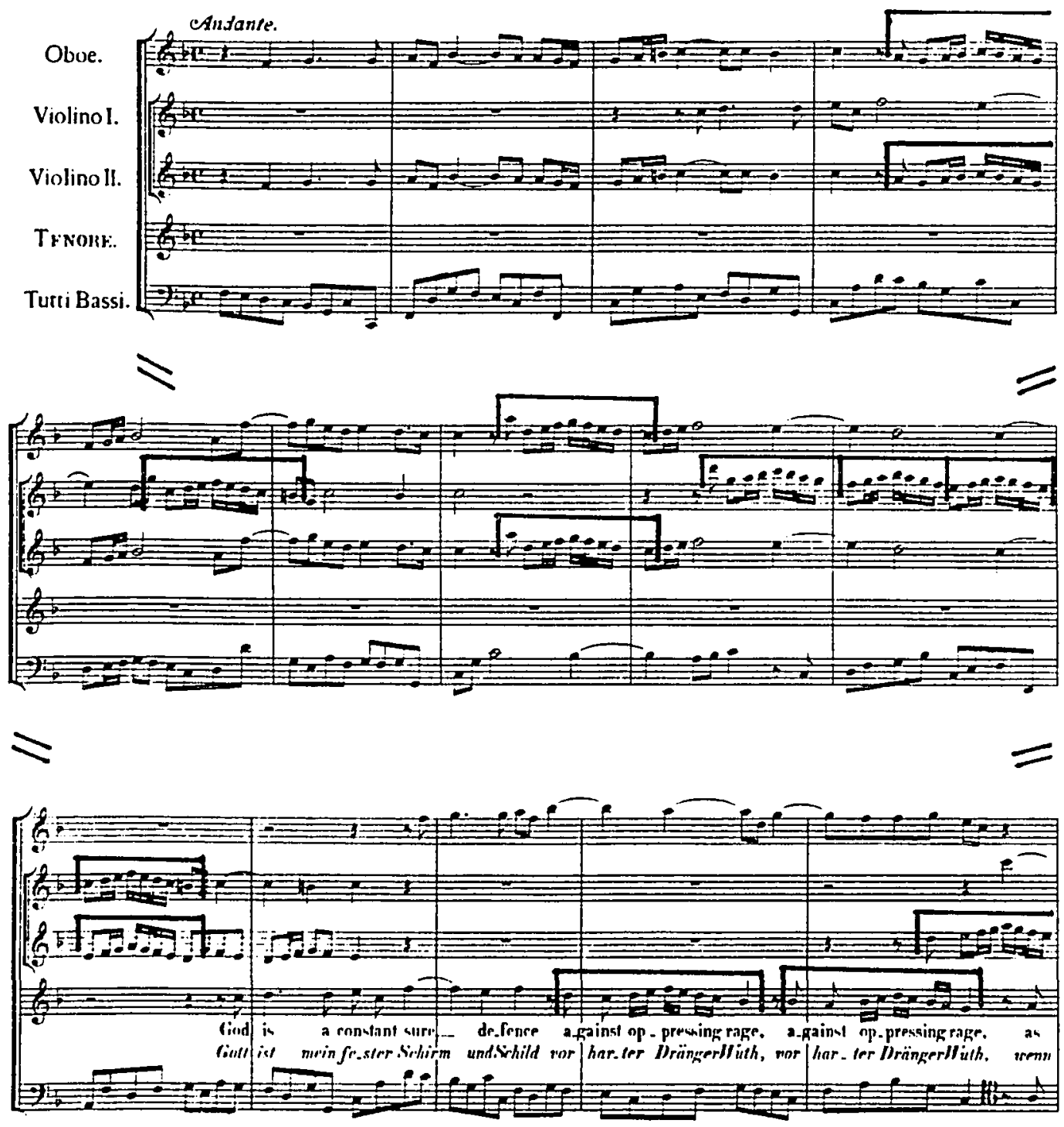
The unifying element may also be a rhythmic pattern which appears in the instrumental accompaniment throughout the solo. Example 7 is a tenor solo in which the unifying element is running sixteenths in the strings and continuo.

Example 7. Unifying sixteenth-note rhythmic pattern in tenor solo, "The waves of the sea rage horribly" from Chandos Anthem IV, 0 sing wate the Lord a new song (H.G. V. 34, p. 120).

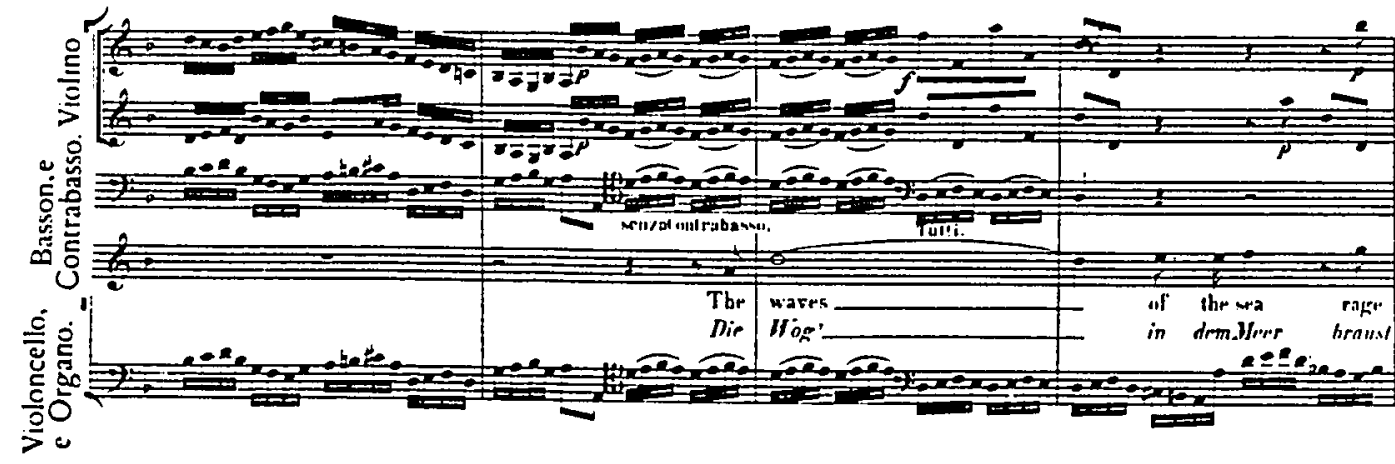

Example 8 is a canto solo in which the unifying factor is running eighths in the continuo, combined with dotted quarter notes in the violins. 
Example 8. Unifying rhythmic pattern of continuo running eighths and violin dotted quarters in canto solo, "It is the Lord that ruleth the sea" from Chandos Anthem $x$, The lord is my light (H.G. V. 35, P. 199).

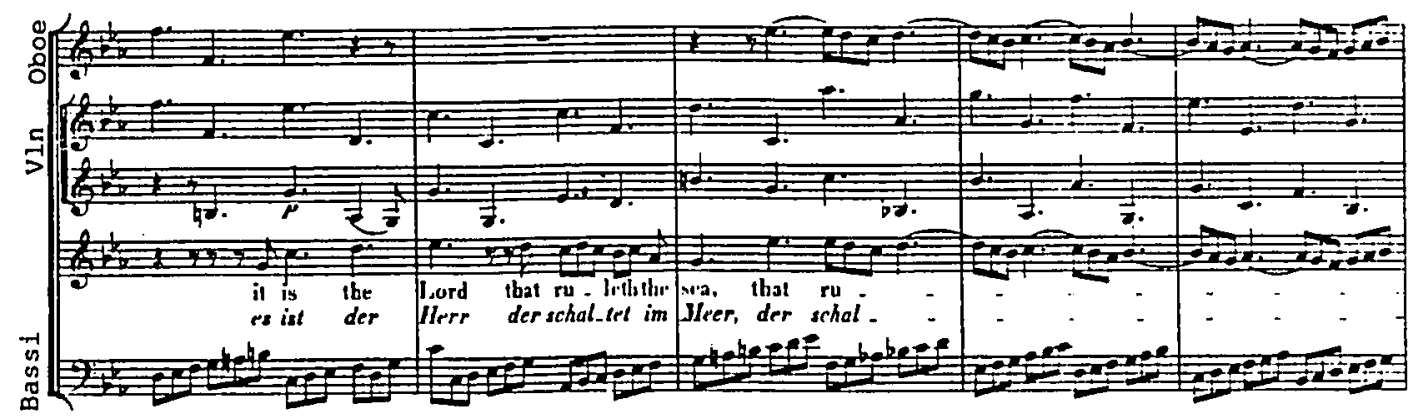

Tonality and harmony were also analyzed, and as can be seen in Appendix A, there appears to be no pattern of voice and tonality association.2

Meter and tempo are charted to determine whether Handel showed a preference in relation to a voice type. As Table 4 shows, there are no significant patterns of voices associated with specific meters or tempi.

2 Appendix $A$ is a chart of the movements and keys in the Chandos Anthems and Chapel Royal works. 
Table 4. Meter and Tempo for the Solos in the Chandos Anthems and Chapel Royal Works

\begin{tabular}{|c|c|c|c|}
\hline ANTHEM \# & SOLO & TEMPO & METER \\
\hline$I$ & Tenor/Chorus & Allegro & $4 / 4$ \\
\hline \multirow[t]{3}{*}{ II } & Tenor & Andante & $4 / 4$ \\
\hline & Tenor & Largo & $4 / 4$ \\
\hline & Tenor & Largo & $3 / 4$ \\
\hline \multirow[t]{2}{*}{ III } & Tenor & Moderato & $4 / 4$ \\
\hline & Canto & Adag10 & $4 / 4$ \\
\hline IV & Tenor & Allegro, ma non presto & $4 / 4$ \\
\hline \multirow[t]{4}{*}{$\mathrm{Va}$} & Tenor & Larghetto & $3 / 4$ \\
\hline & Canto & Not specified & $3 / 8$ \\
\hline & Tenor & Adag10 & $4 / 4$ \\
\hline & Tenor & Iarghetto & $3 / 4$ \\
\hline $\mathrm{Vb}$ & Alto & Andante & $4 / 4$ \\
\hline \multirow[t]{2}{*}{ vIa } & Canto & Un poco adagio & $3 / 4$ \\
\hline & Tenor & Andante & $4 / 4$ \\
\hline VIb & Alto & Larghetto & $3 / 4$ \\
\hline VIC & Alto & Andante & $3 / 4$ \\
\hline \multirow[t]{3}{*}{ VII } & Canto/Chorus & Andante & $4 / 4$ \\
\hline & Tenor & Not spectified & $3 / 4$ \\
\hline & Canto & Andante & $4 / 4$ \\
\hline \multirow[t]{4}{*}{ VIII } & Tenor & Adagio, ma non troppo & $3 / 8$ \\
\hline & Canto & Andante & $4 / 4$ \\
\hline & Tenor & Andante, con moto & $4 / 4$ \\
\hline & Tenor & Adag10 & $12 / 8$ \\
\hline \multirow[t]{4}{*}{ IX } & Tenor & Larghetto & $3 / 8$ \\
\hline & Tenor & Allegro & $4 / 4$ \\
\hline & Bass & Vivace & $3 / 4$ \\
\hline & Canto & Iarghetto & $3 / 4$ \\
\hline \multirow[t]{4}{*}{$\mathrm{x}$} & Tenor/Alto & Andante & $4 / 4$ \\
\hline & Tenor & Largo & $4 / 4$ \\
\hline & Tenor & Allegro & $4 / 4$ \\
\hline & Canto & Allegro, ma non presto & $12 / 8$ \\
\hline \multirow[t]{2}{*}{ XIa } & Tenor & Andante & $3 / 4$ \\
\hline & Canto & Allegro & $4 / 4$ \\
\hline \multirow[t]{2}{*}{$x I b$} & Bass & Andante & $4 / 4$ \\
\hline & Alto & Andante & $4 / 4$ \\
\hline \multirow[t]{4}{*}{$\mathrm{XII}$} & Alto & Andante Allegro & $3 / 4$ \\
\hline & Bass & Moderato ma non adag10 & $4 / 4$ \\
\hline & Alto & Not specified & $4 / 4$ \\
\hline & Bass & Andante & $4 / 4$ \\
\hline
\end{tabular}


Table 4. (continued)

\begin{tabular}{|c|c|c|c|}
\hline ANTHEM \# & SOLO & TEMPO & METER \\
\hline & & & \\
\hline XIII & Alto & Moderato & $4 / 4$ \\
\hline & Bass & Larghetto & $4 / 4$ \\
\hline & Canto & Not speclfled & $3 / 8$ \\
\hline & Tenor & Allegro & $4 / 4$ \\
\hline XIV & Bass & Allegro & $4 / 4$ \\
\hline & Canto & Larghetto & $4 / 4$ \\
\hline & Bass & Andante & $3 / 8$ \\
\hline XV & Tenor & Allegro Moderato & $4 / 4$ \\
\hline XVI & Bass & Andante Larghetto & $3 / 4$ \\
\hline IV-a & Tenor & Not specified & $4 / 4$ \\
\hline VId & Bass & Not specifled & $3 / 4$ \\
\hline
\end{tabular}

\section{TEXT SUBJECTS}

The text subject of each solo was described with a one-word adjective and then grouped by category to determine whether a particular characteristic was associated with a specific voice. (See Table 5.) Bass and alto solos were analyzed from the oratorio, Messiah, since there are so few bass and alto solos in the Chandos Anthems and Chapel Royal works. Messiah was chosen since there are no character roles which might be associated with a particular voice.

In the opera and operatic oratorio, there were certain expectations regarding the appropriate voice to be assigned to a role. Edward Dent commented, ". . our ancestors liked to associate the noblest heroes of antiquity with high soprano voices, relegating tenors and baritones to 
subordinate parts, and basses to those of tyrants or sages."3 Solo texts were studied to determine whether a solo subject in the anthems was associated with a particular voice as would be expected in opera and operatic oratorio.

The solos fall into five main categories of subject matter: praise, protection, oppression, prayer, and punishment. Rraise includes texts which proclaim praise or rejoicing, admonish people to sing to the Lord, or invite them to worship the Lord. Protection covers texts which mention God's care and/or His protection of His people. oppression includes solos whose subject is the oppression or the troubles of God's people. Prayers of penitence and supplication are charted in the category of Prayer. Runishment describes any text which refers to God's wrath on His enemies, or on the enemies of His people. Solos whose texts are two contrasting or non-contrasting ideas are charted under two categories.

The subject of most of the solos is a general one of praise, or recognition of God's care and protection, as can be seen in Table 5. No clear patterns emerge which indicate an association of a special subject with any particular voice.

3 Edward J. Dent, "The Operas," Handel: A Symposium, edited by Gerald Abraham, (London: Oxford University Press,
1954), 15-16. 
Table 5. Subject Matter for the solos in the Chandos Anthems and Chapel Royal works

\begin{tabular}{|c|c|c|c|c|c|c|}
\hline ANTHEM \# & SOLO & PRAISE & PROTECTION & OPPRESSION & PRAYER & PUNISHMENT \\
\hline I & Tenor/Chorus & $\mathbf{x}$ & & & & \\
\hline \multirow[t]{3}{*}{ II } & Tenor & & $\mathrm{x}$ & & & \\
\hline & Tenor & & $\mathrm{x}$ & & & \\
\hline & Tenor & $x$ & & & & \\
\hline \multirow[t]{2}{*}{ III } & Tenor & & & & $\mathrm{x}$ & \\
\hline & Canto & & & & $x$ & \\
\hline IV & Tenor & $\mathrm{x}$ & & $\mathrm{x}$ & & \\
\hline \multirow[t]{4}{*}{$\mathrm{Va}$} & Tenor & $\mathrm{x}$ & & & & \\
\hline & Canto & $\mathrm{x}$ & $\mathbf{x}$ & & & \\
\hline & Tenor & & $\mathbf{x}$ & & & $\mathrm{x}$ \\
\hline & Tenor & & $\mathbf{x}$ & & & \\
\hline $\mathrm{Vb}$ & Alto & $\mathbf{x}$ & & & & \\
\hline \multirow[t]{2}{*}{ VIa } & Canto & & & $\mathbf{x}$ & & \\
\hline & Tenor & $\mathbf{x}$ & & $\mathbf{x}$ & & \\
\hline VIb & Alto & & $x$ & $\mathrm{x}$ & & \\
\hline VIC & Alto & & & $\mathbf{x}$ & & \\
\hline \multirow[t]{3}{*}{ VII } & Canto/Chorus & $\mathbf{x}$ & & & & \\
\hline & Tenor & $\mathbf{x}$ & & & & \\
\hline & Canto & & $x$ & & & \\
\hline \multirow[t]{4}{*}{ VIII } & Tenor & & $\mathrm{x}$ & & & \\
\hline & Canto & $\mathrm{x}$ & & & & \\
\hline & Tenor & & $\mathbf{x}$ & & & \\
\hline & Tenor & $\mathbf{x}$ & & & & \\
\hline \multirow[t]{4}{*}{$I X$} & Tenor & $\mathbf{x}$ & & & & \\
\hline & Tenor & $\mathbf{x}$ & & & & \\
\hline & Bass & $\mathbf{x}$ & & & & \\
\hline & Canto & & $\mathrm{X}$ & & & \\
\hline \multirow[t]{4}{*}{$x$} & Tenor/Alto & & $\mathbf{x}$ & & & \\
\hline & Tenor & $\mathrm{x}$ & & & & \\
\hline & Tenor & $\mathbf{x}$ & $\mathbf{x}$ & & & \\
\hline & Canto & $\mathrm{x}$ & & & & \\
\hline
\end{tabular}


Table 5. (continued)

\begin{tabular}{|c|c|c|c|c|c|c|}
\hline ANTHEM \# & SOLO & PRAISE & PROTECTION & OPPRESSION & PRAYER & PUNISHMENT \\
\hline \multirow[t]{2}{*}{$\mathrm{XIa}$} & Tenor & & & & & $\mathrm{x}$ \\
\hline & Canto & $\mathrm{x}$ & & & & \\
\hline \multirow[t]{2}{*}{$\mathrm{XIb}$} & Bass & & & & & $\mathrm{x}$ \\
\hline & Alto & $\mathrm{x}$ & & & & $x$ \\
\hline \multirow[t]{4}{*}{ XII } & Alto & $x$ & & & & \\
\hline & Bass & $x$ & & & & \\
\hline & Alto & $x$ & $\mathrm{x}$ & & & \\
\hline & Bass & $x$ & $x$ & & & \\
\hline \multirow[t]{5}{*}{ XIII } & Alto & & & & & \\
\hline & Bass & & & & & \\
\hline & Canto & & & & & \\
\hline & Tenor & & & & & \\
\hline & Bass & & & & & \\
\hline \multirow[t]{3}{*}{ XIV } & Canto & & & & & \\
\hline & Bass & & & & & \\
\hline & Tenor & & & & & \\
\hline XV & Bass & $x$ & & & & \\
\hline$X V I$ & Tenor & & $\mathrm{x}$ & & & \\
\hline$I V-A$ & Bass & $\mathbf{x}$ & & & & \\
\hline$V I-D$ & Bass & $x$ & & $x$ & & \\
\hline
\end{tabular}

IV. POSITION IN WORK

Solos were examined for the position and order in which they appeared in the anthems to determine whether a pattern was followed. It was immediately apparent that there was no pattern. Appendix A gives the overall scheme of all the anthems. 


\section{HANDEL'S REUSE OF SOLOS}

Handel often used a solo in more than one work, assigning it to a different voice. Beeks noted that "Handel was unable to revise a piece minimally. He seems to have felt a need always to branch off in a new direction."4 only seven solos in the anthems were reused without drastic revisions, and they provide some further insights.

The canto solo, "Make me a clean heart, o Lord" in Anthem III, was taken from the alto solo, "When thou took'st upon Thee to deliver Man", in Te Deum for the Peace of Utrecht (1713). It was almost a direct transcription, except for the change from alto clef to treble clef, and the transposition from $D$ minor to $C$ minor. Examples $9 a$ and $9 b$ compare the two versions. There is some octave displacement, as in measure 7, but otherwise, there is minimal difference between the two versions. After the first section of the solo, Handel composed new material for the soloist in Anthem III. The Te Deum continues with music for the chorus.

4 Beeks, 621. 
Example 9a. Comparison between alto solo, "When Thou took'st upon Thee to deliver Man" from Te Deum for the Peace of Utrecht, 1713 (H.G. v. 31, p. 24), and canto solo, "Make me a clean heart, 0 God," Example $9 b$.
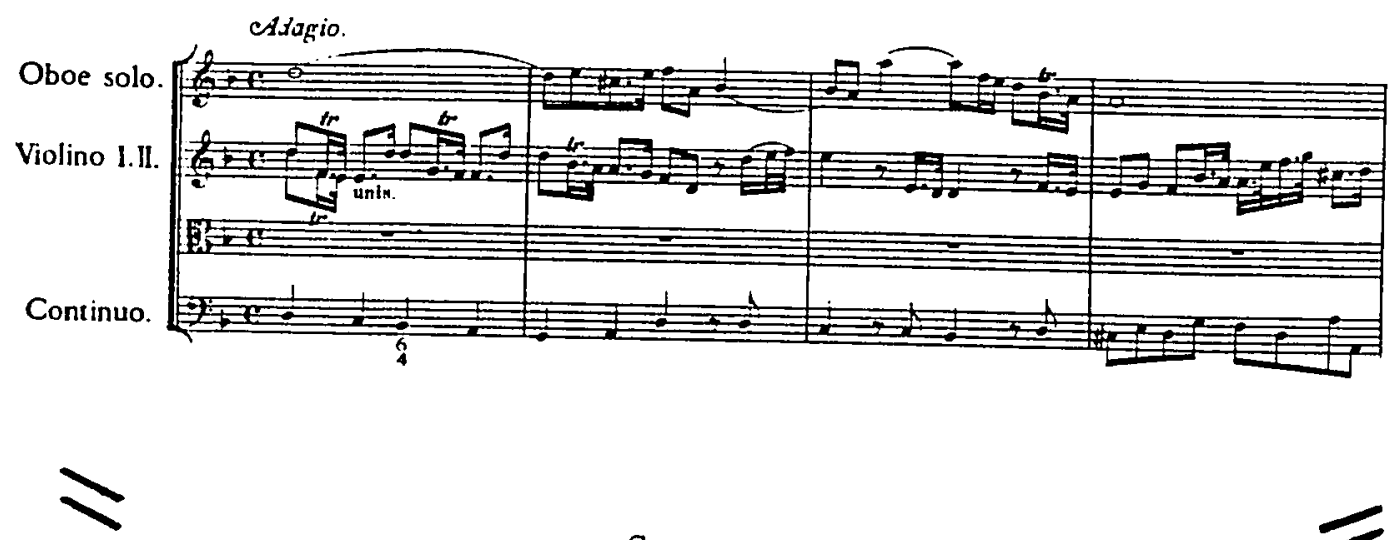

Compare octave displacement,

(7) Example $9 \mathrm{~b}$, measure 7
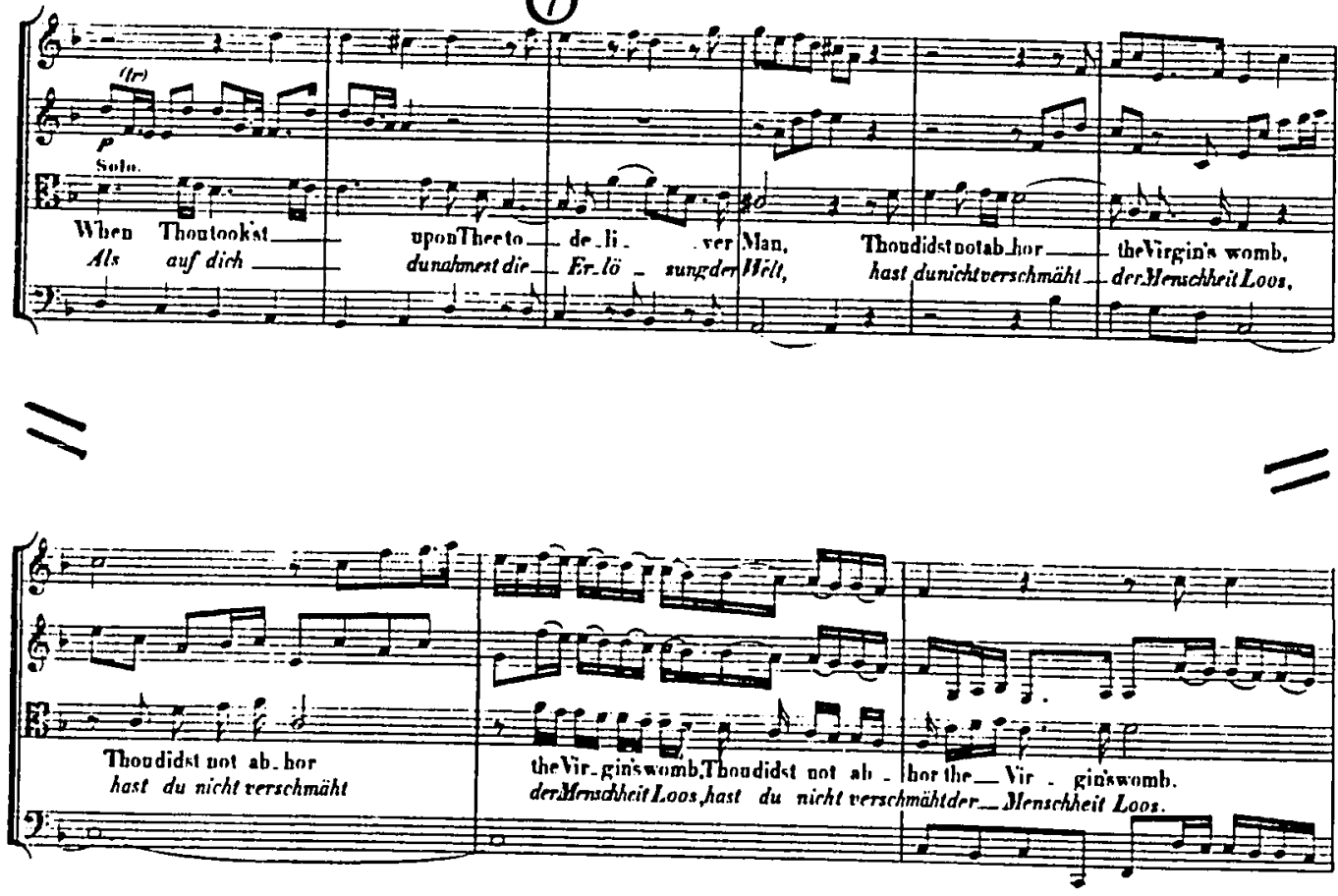
Example 9b. Comparison between canto solo, "Make me a clean heart, O God" from Chandos Anthem III, Have mercy upon me (H.G. V. 34, P. 102), and alto solo, "When Thou took'st upon Thee to deliver Man," Example 9a.
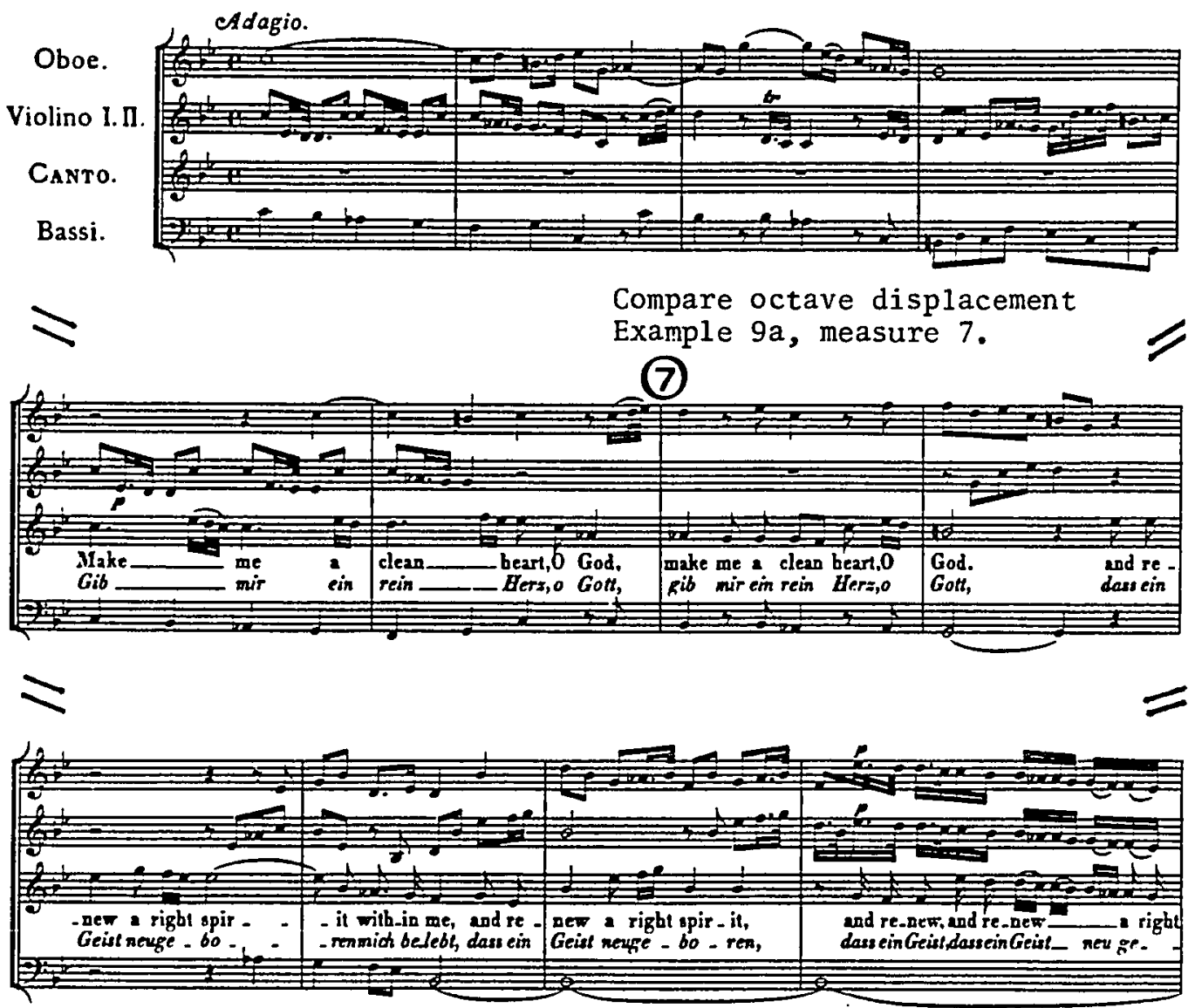

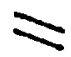

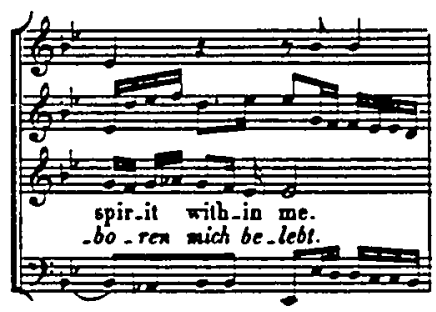


The canto solo, "O sing unto the Lord a new song" in Anthem IV, was taken from an earlier Chapel Royal anthem, $Q$ sing unte the Iord a new song, No. IV-A. In the Chapel Royal work, the solo was assigned to a tenor. Handel transposed the solo from $G$ minor to $F$ minor for the Chandos anthem, but made no significant revisions solely to accommodate the soprano voice. Revisions seem to be entirely artistic, as can be seen by comparing Example $10 \mathrm{a}$ and $10 \mathrm{~b}$.

Example 10a. Comparison between tenor solo, "O sing unto the Lord a new song" from Chapel Royal anthem, $\varrho$ sing unte the Lord a new song (H.G. v. 36, p. 219), and soprano solo, "O sing unto the Lord a new song," Example $10 \mathrm{~b}$.

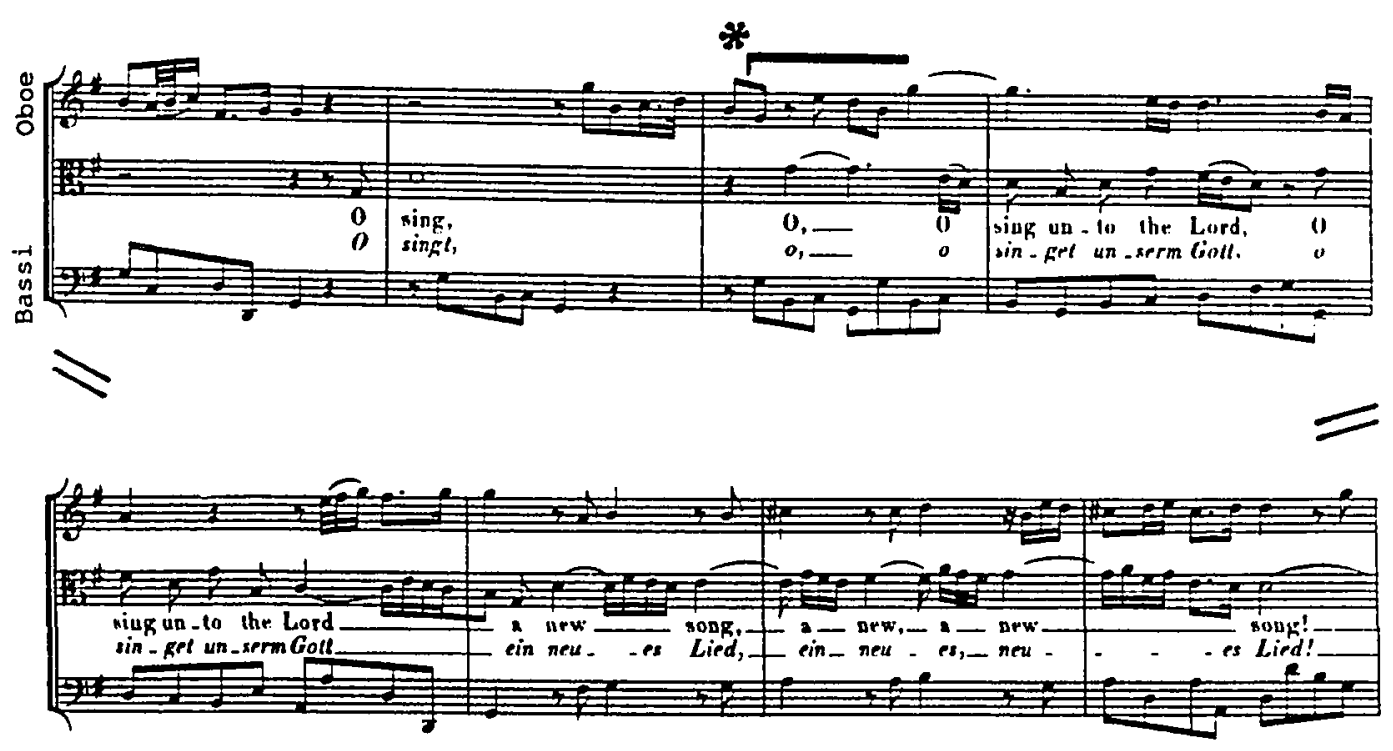


Example 10b. Comparison between soprano solo, "O sing unto the Lord a new song" from Chandos Anthem IV, 0 sing unto the Lord a new song (H.G. v. 34, p. 112), and tenor solo, "O sing unto the Lord a new song," Example $10 \mathrm{a}$.

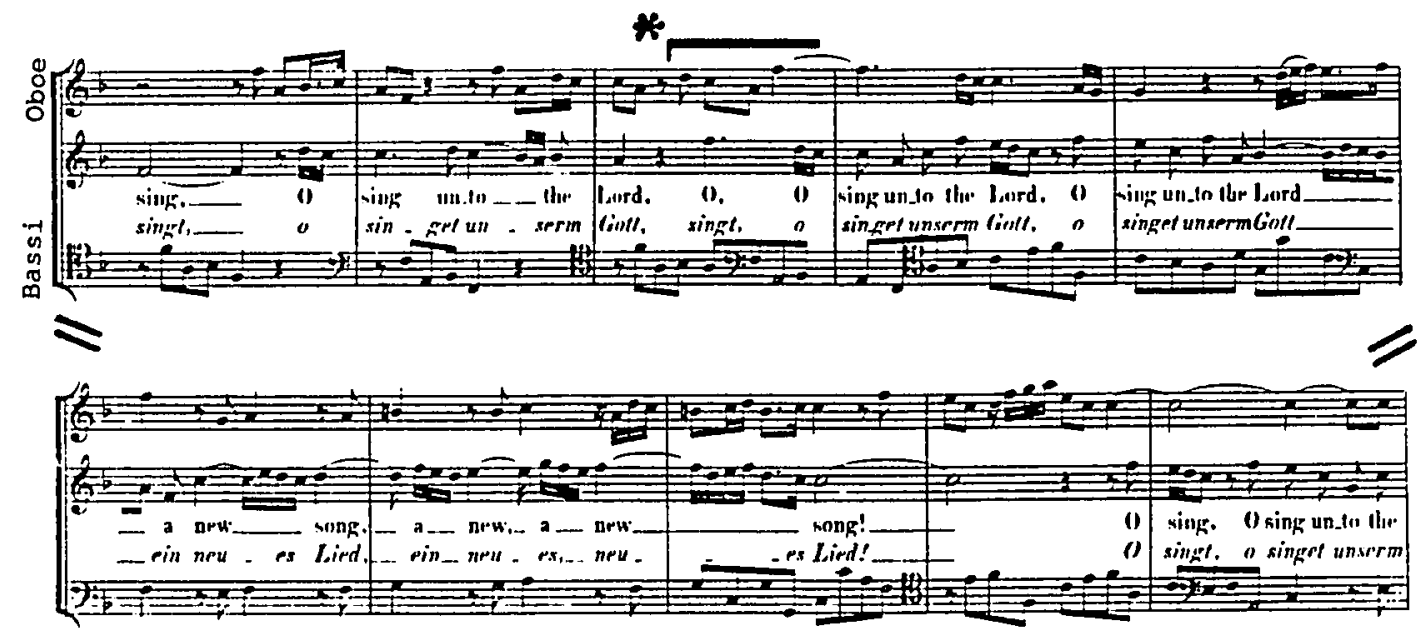

"God is very greatly to be feared", a tenor solo in Anthem VII, was borrowed from a countertenor solo in $\mathrm{Te}$ Deum in D majer (1714), "When Thou took'st upon Thee to deliver man." The solo was transposed from G minor to E minor, but revised very little. The Te Deum solo is the opening of a chorus, but in Anthem VII, the solo is a separate movement. With the exception of a closing ritornello, and some artistic changes, including accommodation for a different text, the solos are very similar. (Compare $11 \mathrm{a}$ and 11b.) 
Example 1la. Comparison between tenor solo, "God is very greatly to be fear'd" from Chandos Anthem VII, My song shall be alway (H.G. v. 35, p.14), and countertenor solo, "When Thou tookest upon Thee to deliver man," Example 11b.
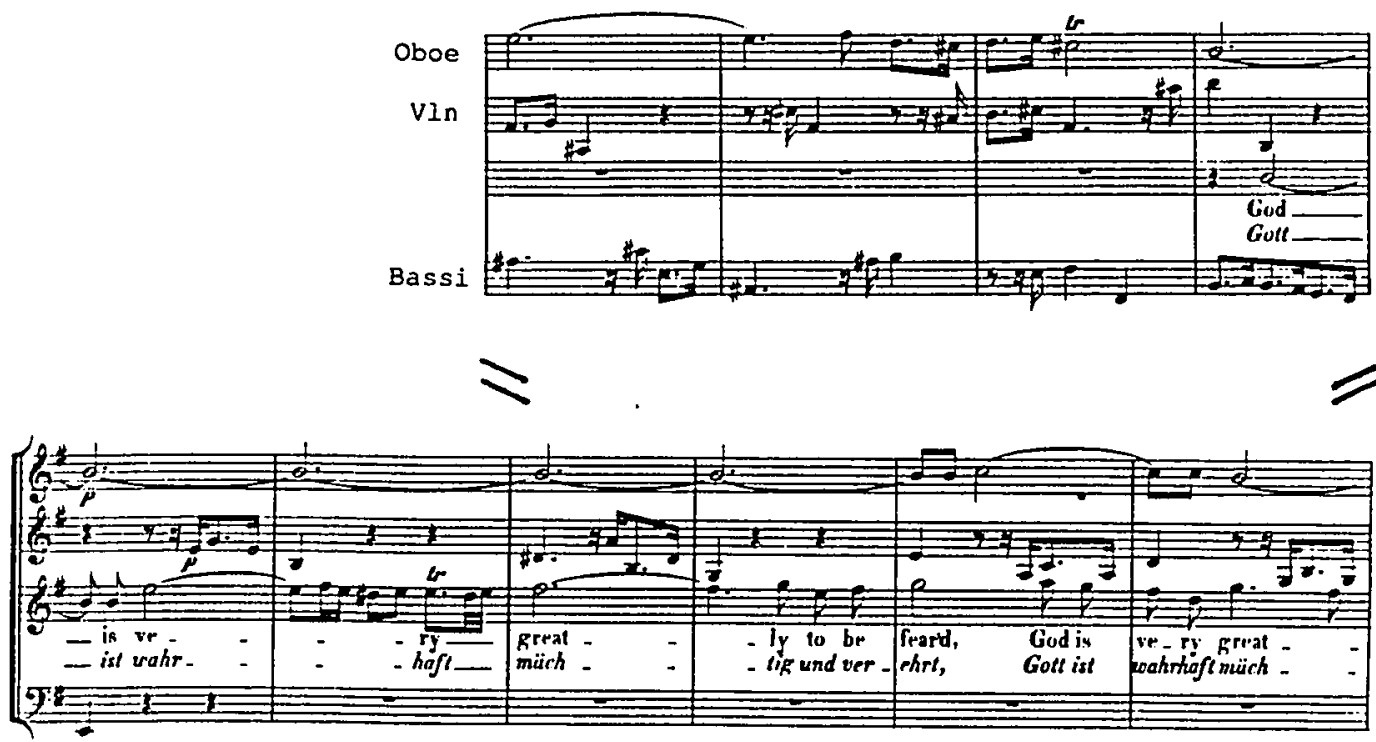

$\approx$

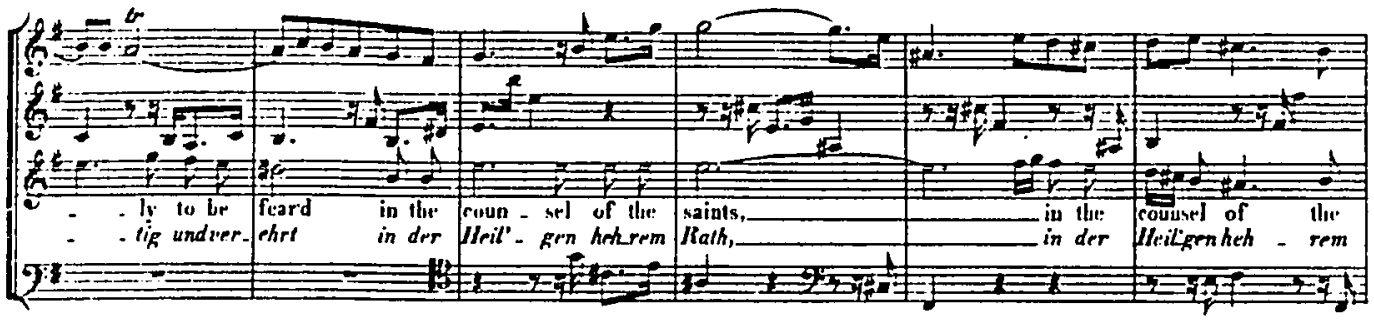


Example 11b. Comparison between countertenor solo, "When Thou tookest upon Thee to deliver man" from Te Deum in D majer, 1714 (H.G. v. 37, P. 12), and tenor solo, "God is very greatly to be fear'd," Example 11a.

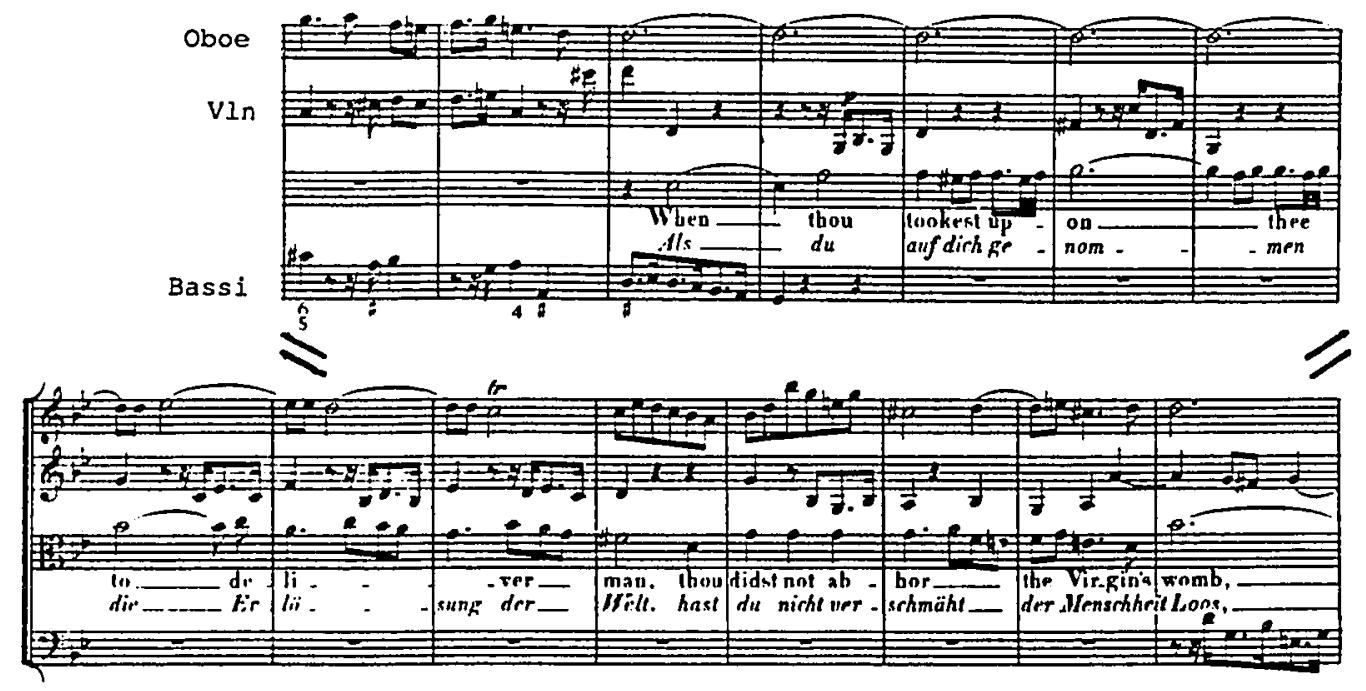

"Tell it out among the heathen" appeared in three different works for three different voices. It appeared first in Anthem VIII as a tenor solo (H.G. v. 35, p. 66-67), next in Chapel Royal anthem $\mathrm{Vb}$ as a bass solo (Vb, H.G. v. 34, p. 187-188), then in the oratorio, Balshazzar (1744) as a canto solo (H.G. v. 19, p. 242-243). These are identical with one exception. The two anthem solos are in $A$ major, while the oratorio solo is in G major.

The tenor solo, "Praise Him all ye that in His house attend" in Anthem IX was reused as a soprano solo, "No more disconsolate I'll mourn," in Deborah. With the exception of accommodating for a different text, the solo in Reborah was 
an exact transcription. Examples $12 \mathrm{a}$ and $12 \mathrm{~b}$ are a comparison of the two solos.

Example 12a. Comparison between tenor solo, "Praise Him all ye that in His house attend" from Chandos Anthem IX, 0 praise the Lord with one consent (H.G. v. 35, p. 113), and soprano solo, "No more disconsolate I'll mourn," Example $12 \mathrm{~b}$.

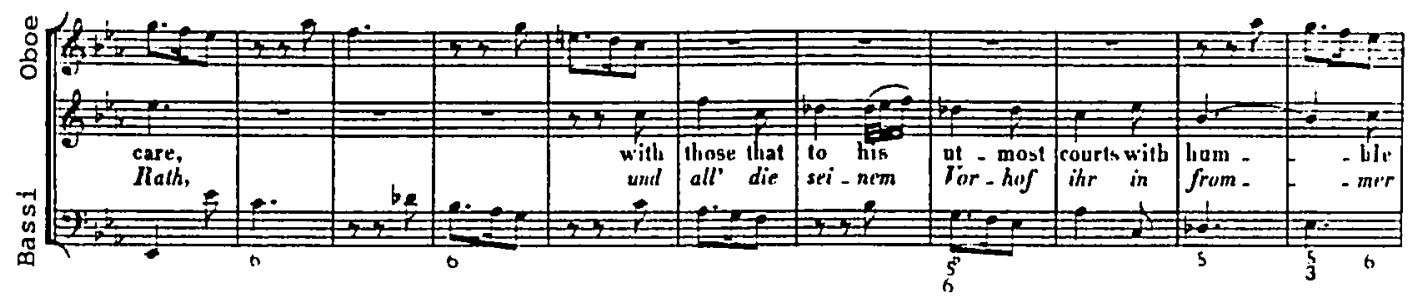

Example 12b. Comparison between soprano solo, "No more disconsolate I'll mourn" from Deborah (H.G. v.29, p.164) and tenor solo, "Praise Him all ye that in His House attend," Example $12 \mathrm{a}$.

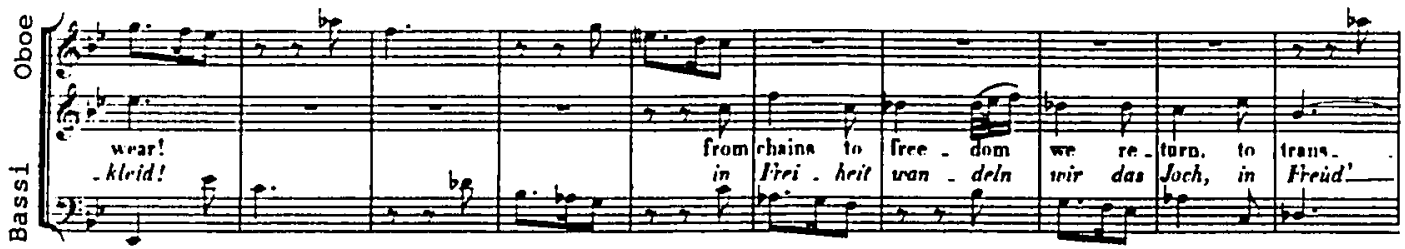

Another tenor solo in Anthem IX became a soprano solo in Deborah; "For this our truest int'rest is" became "Our fears are now for ever fled." Because of the syllabic similarity of the text, this oratorio solo was a very close transcription of the original solo. Example 13 shows the remarkable similarity of the two solos. 
Example 13a. Comparison between tenor solo, "For this our truest int'rest is" from Chandos Anthem IX, 0 praise the Iord with one consent (H.G. v. 35, p. 115), and soprano solo, "Our fears are now for ever fled," Example $13 \mathrm{~b}$.

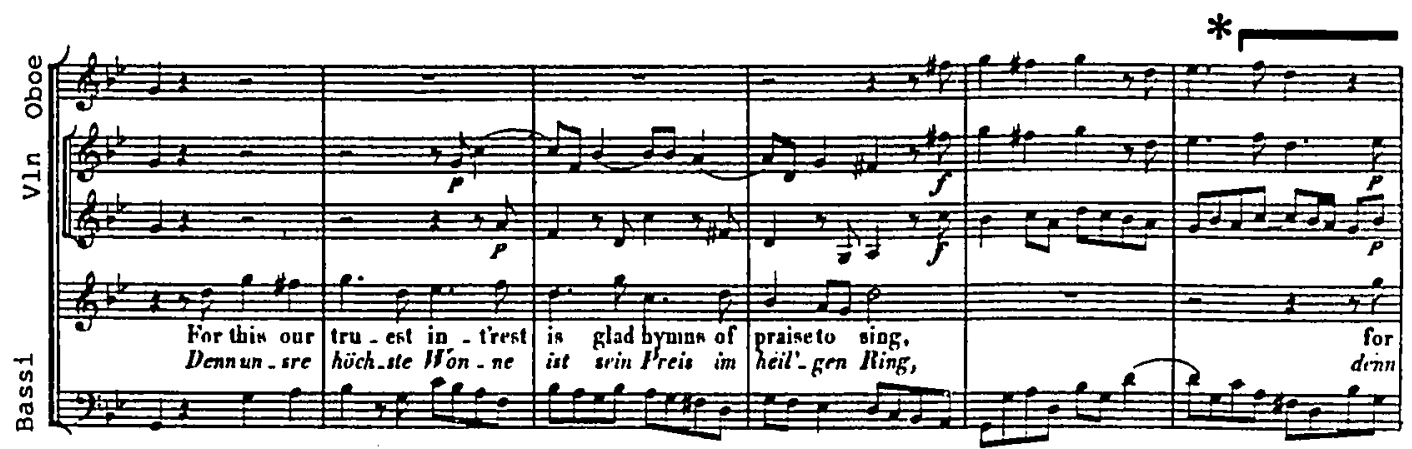

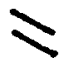

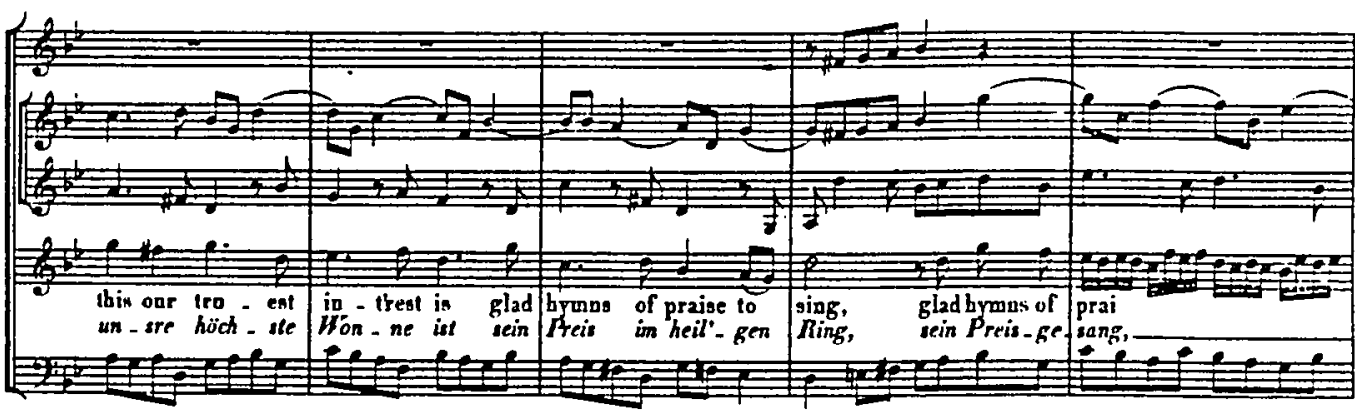

$\mathcal{Z}$

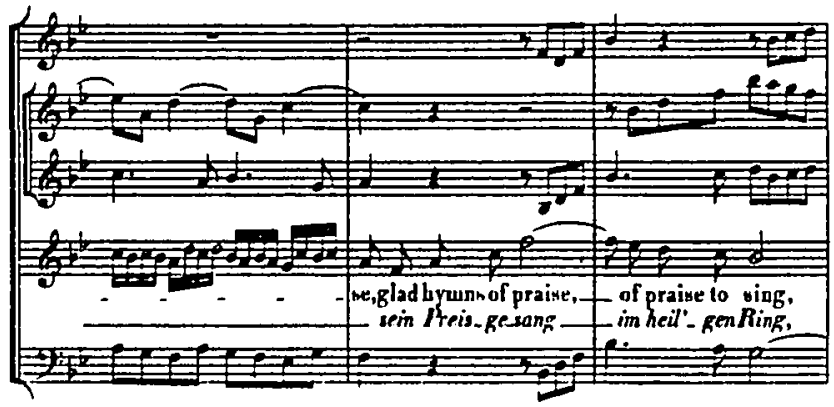


Example 13b. Comparison between soprano solo, "Our fears are now for ever fled" from the oratorio Deborah, 1733, (H.G. v. 29, p.191), and tenor solo, "For this our truest int'rest is," Example 13a.
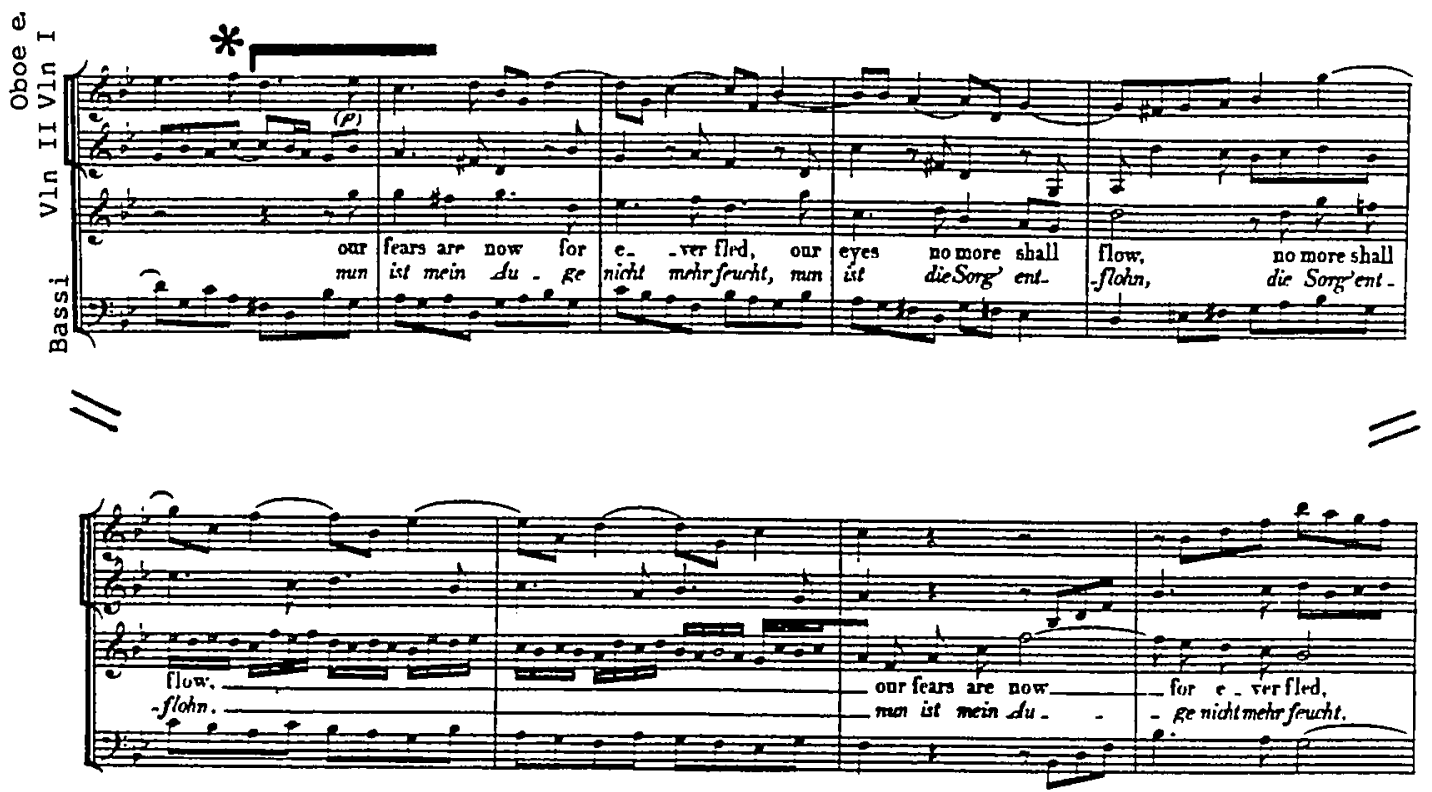

$\mathcal{7}$

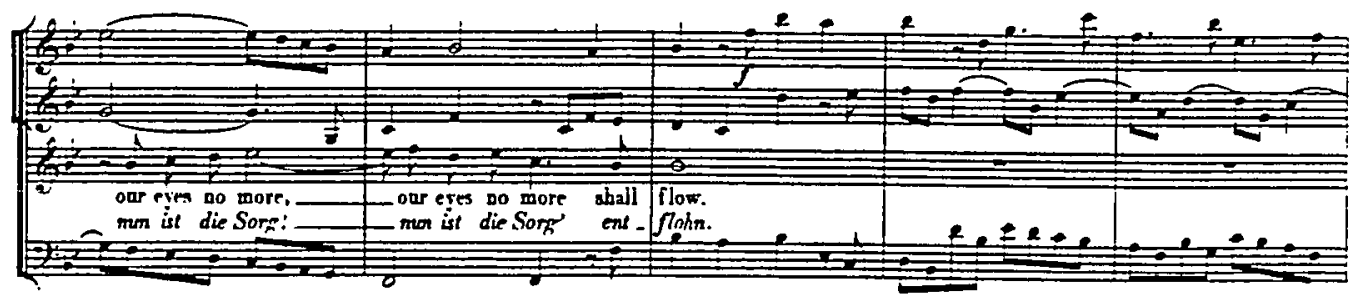

The examination of solos in the chandos Anthems includes five areas in which solos were analyzed and compared, to determine if patterns exist which would affect reassigning a solo to a voice other than the one indicated. The five areas are: 1) instrumentation, 2) style, 3) subject 
matter, 4) position in work, and 5) Handel's reuse of solos. Characteristics which might affect reassignment of solos are found only in the area of instrumentation, which includes an examination of vocal and instrumental counterpoint. These characteristics suggest guidelines, which are presented in Chapter 5, for reassigning solos in the Chandos Anthems. 
Chapter 5

CONCLUSION

I. SUMMARY

Handel's Chandos Anthems represent all the components of his vocal and choral composition and are the beginning of the English oratorio. They were written for a very select group of musicians, employed by the Duke of Chandos at his palatial Cannons estate near London. Most of these musicians were professionals from London theaters and the Chapel Royal choirs. These musicians included countertenors and castrati, which may present problems of range when assigning the solos from the anthems. A choral director may not have soloists to perform the solos as indicated and may decide to reassign the solo to another voice part. This may be possible without sacrificing Handel's intentions or the integrity of the composition.

Every choral conductor should be aware of authentic performance practice; yet, they often find that authentic performance practice is not practical. A director who assigns a Chandos Anthem solo to another voice is certainly not following authentic performance practice, but may not be totally lacking in sensibility to the composer's wishes. Donnington suggested that performance situations "may be 
almost indefinitely variable within a given style."l He does not recognize only two sides to the authentic performance practice issue. He says, "It is also possible to take up a middle position, allowing for a measure of compromise adjusted to the practical circumstances of a given situation."2 In performing the chandos Anthems, a practical solution to the lack of a suitable soloist may be to assign a solo to a voice other than the one indicated in the anthem.

Handel himself was known to reassign solos when available soloists' voices were different than the voices originally assigned to the solos. Messiah is an anthem oratorio whose solos are very similar to the Chandos Anthem solos, and Larsen commented on Handel's reassignment of solos:

Messiah has no fixed characters with whom the oratorio is connected, so that any individual aria can be transferred from one soloist to another, from tenor to soprano, alto or bass, without the coherence of the text being in the least affected. Handel has made considerable use of this freedom. 3

Lang also noted Handel's transposition of solo voices and maintained the acceptibility of this practice today. He

\footnotetext{
1 Robert Donington, "The Present Position of Authenticity," Performance Practice Review, Vol. 2, No. 2 (Fall,
1989), 122.

2 Ibid. 117.

3 Jens Peter Larsen, Handel's Messiah: Origins, Compesition Sources, (New York: Norton, 1972), 188.
} 
cautions that care must be taken when changing voices, to suit the voice to the music. ${ }^{4}$

This thesis has examined Handel's compositional practices, to determine whether patterns exist which would affect reassigning the solos. The examination included formal analysis of the Chandos Anthem solos, along with other selected works. It also entailed charting comparisons of various other aspects of the compositions. The total analysis covered five basic areas: 1) instrumentation, 2) style, 3) text subjects, 4) position in work, and 5) Handel's reuse of solos. The purpose of this research was to suggest a set of guidelines for reassigning the solos to another voice. Characteristics which might affect reassignment of solos were found only in the area of instrumentation and counterpoint.

II. GUIDELINES

The conclusions drawn from this study have produced the following recommendations:

1. Do not assign a bass sole to another voice when the continue doubles the voice. This would be contrary to Handel's practice, and would produce an undesirable sonority.

4 Lang, 168-173. 
2. Do not assign the bass singer a solo from another voice if it would take the voice lower than the continuo. This would be contrary to Handel's practice. It would also be totally opposed to the concept of a continuo foundation for Baroque music. The result would be a muddy sonority which would negate the effectiveness of the solo.

3. If a sole is reassigned to the bass voice, it might also be necessary to revoice the oboe part. The combination of the bass voice with the oboe occurred in only one solo in the works studied. Revoicing which pairs these should be carefully considered.

4. Match the voice to the solo, using a critical ear to judge the results. One author noted that Handel "wrote always for the ear, never for the eye of the score-reader or the tidy mind of the mathematician."5 Acknowledging this, it is very important to evaluate the reassignment of solos with the ear.

The guidelines which emerged from this study suggest ways in which solos in the Chandos Anthems may be assigned to alternate voices. It is always advisable to perform the anthem solos as indicated, if possible; however, practical circumstances often make this impossible. If it becomes

5 Dean, The New Grove Handel, 84. 
necessary to reassign solos, it is wise to do so only after careful consideration of the solo and the available soloists. Table 6 is a practical application of the above guidelines. Possibilities have been suggested for reassigning the solos in Chandos Anthem VIII, e come let us sing unto the Iord.

Table 6. Possibilities for Revoicing Solos in Chandos Anthem VIII, 0 come, let us sing unto the Iord

\begin{tabular}{|c|c|c|c|}
\hline SOLO & $\begin{array}{c}\text { ASSIGNED } \\
\text { ZOICE }\end{array}$ & $\begin{array}{l}\text { POSSIBIE } \\
\text { REVOICING }\end{array}$ & PITCH \\
\hline o come, let us worship & Tenor & Soprano & $8 \mathrm{va}$ higher \\
\hline Tell it out among the heathen & Alto & Tenor & At pitch \\
\hline & & Bass & At pitch \\
\hline O magnify the Lord & Soprano & Tenor & 8va lower \\
\hline The Lord preserveth & Tenor & Alto & At pitch \\
\hline
\end{tabular}

In addition to the difficulty encountered in assigning solos in the Chandos Anthems, a choral conductor may also find it difficult having an SATB choir singing music in which the alto voice is assigned a part written for countertenor. The range will often be too low for the alto voice. In addition, the tenor line frequently lies above the countertenor or alto line and is very high. Even allowing 
for baroque pitch, the problems remain. Further study is recommended which would revoice any of the four-voice anthems, making them more appropriate for an SATB choir. It is difficult to close this study without a recommendation that choral directors give more consideration to the performance of at least one of the Chandos Anthems. They present exciting and challenging music and are deserving of more attention. They are, as Burney says, "noble, majestic, and frequently sublime."6

6 Charles Burney, An Account of the Musical Performances in Westminster Abbey and the Pantheon, (London: T. Payne and Son, 1785, 41 . 
APPENDIX A

SCHEMATIC OF MOVEMENTS IN THE CHANDOS ANTHEMS 


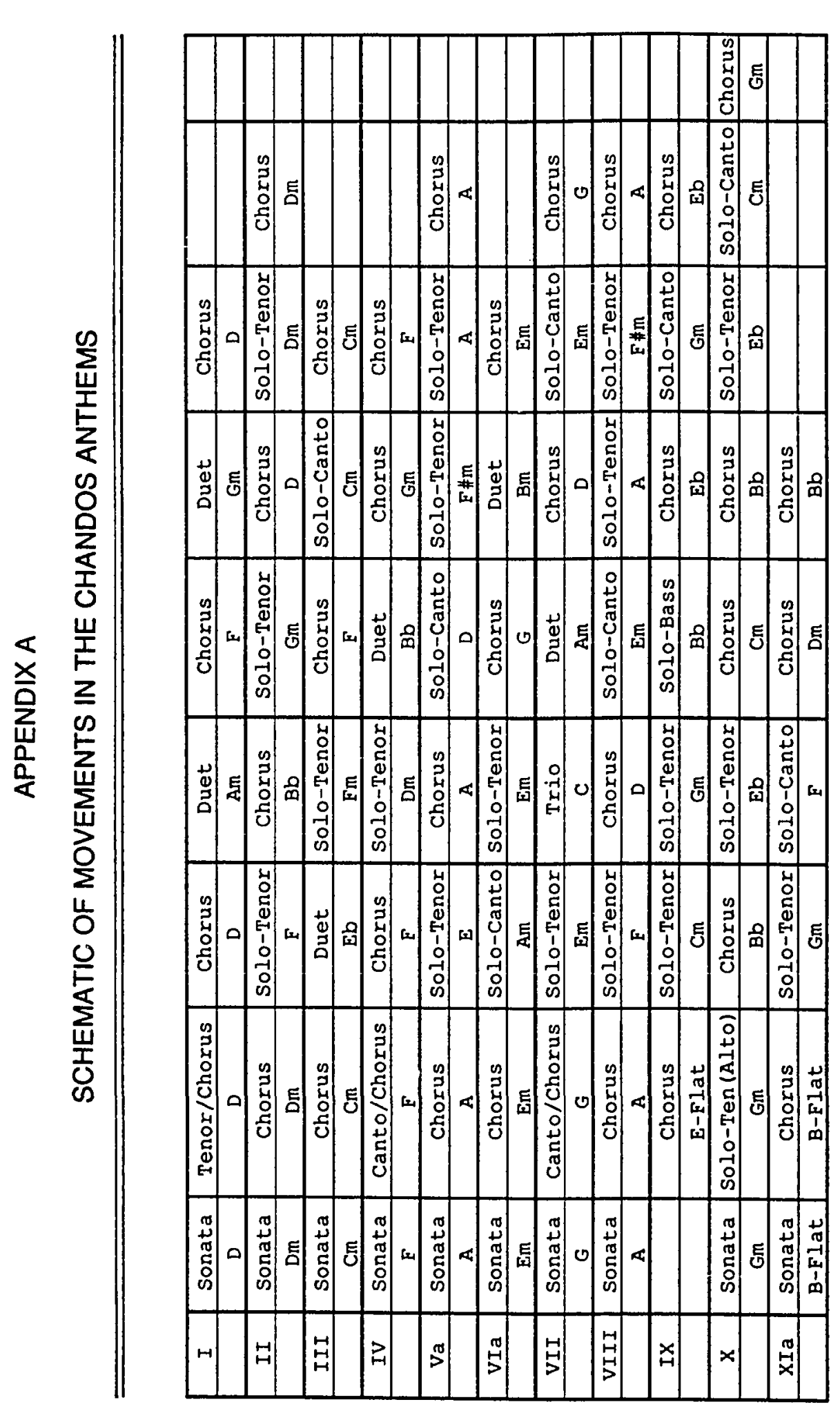


APPENDIX B

SOLOS IN THE CHANDOS ANTHEMS

AND CHAPEL ROYAL WORKS 


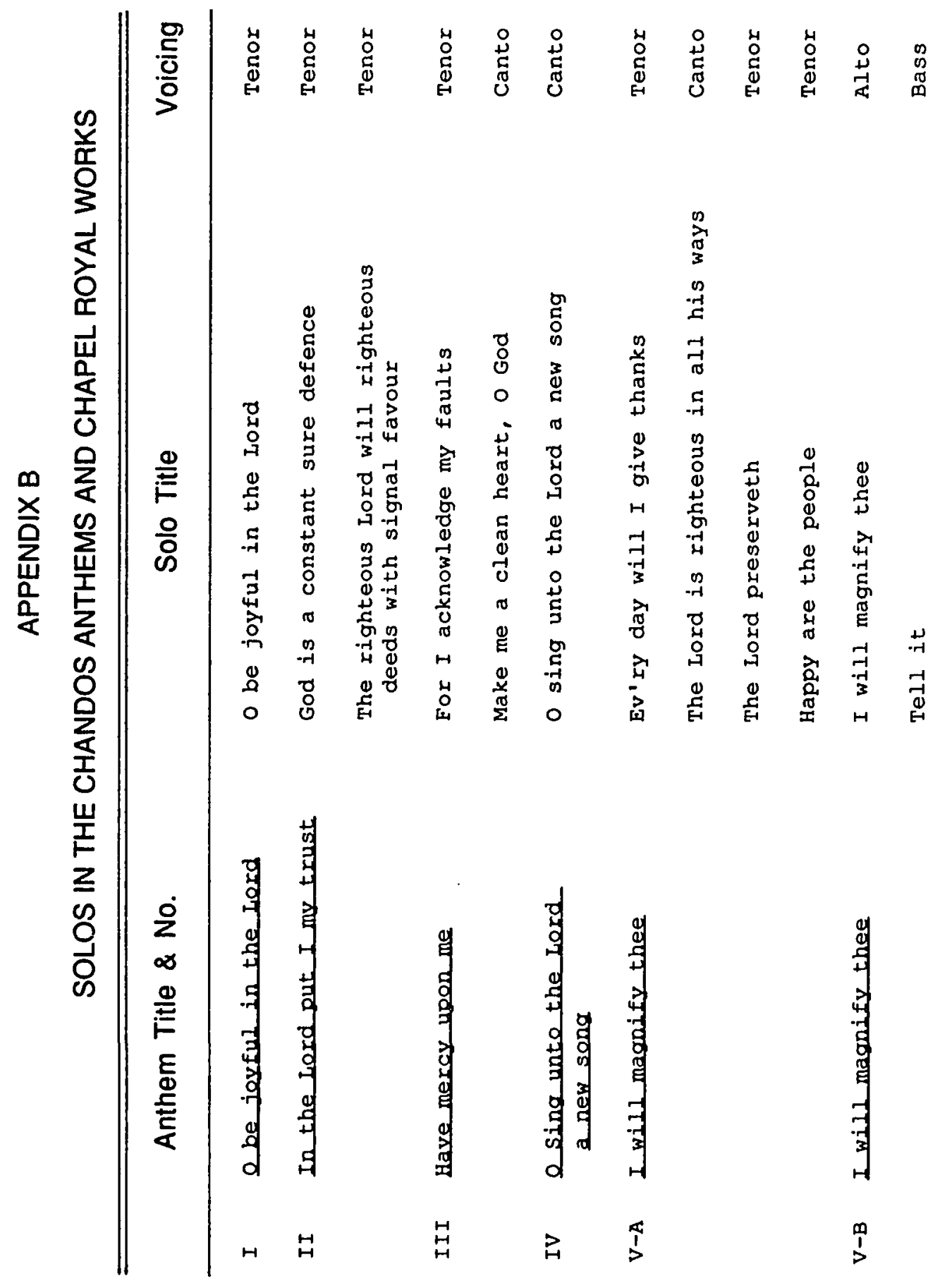




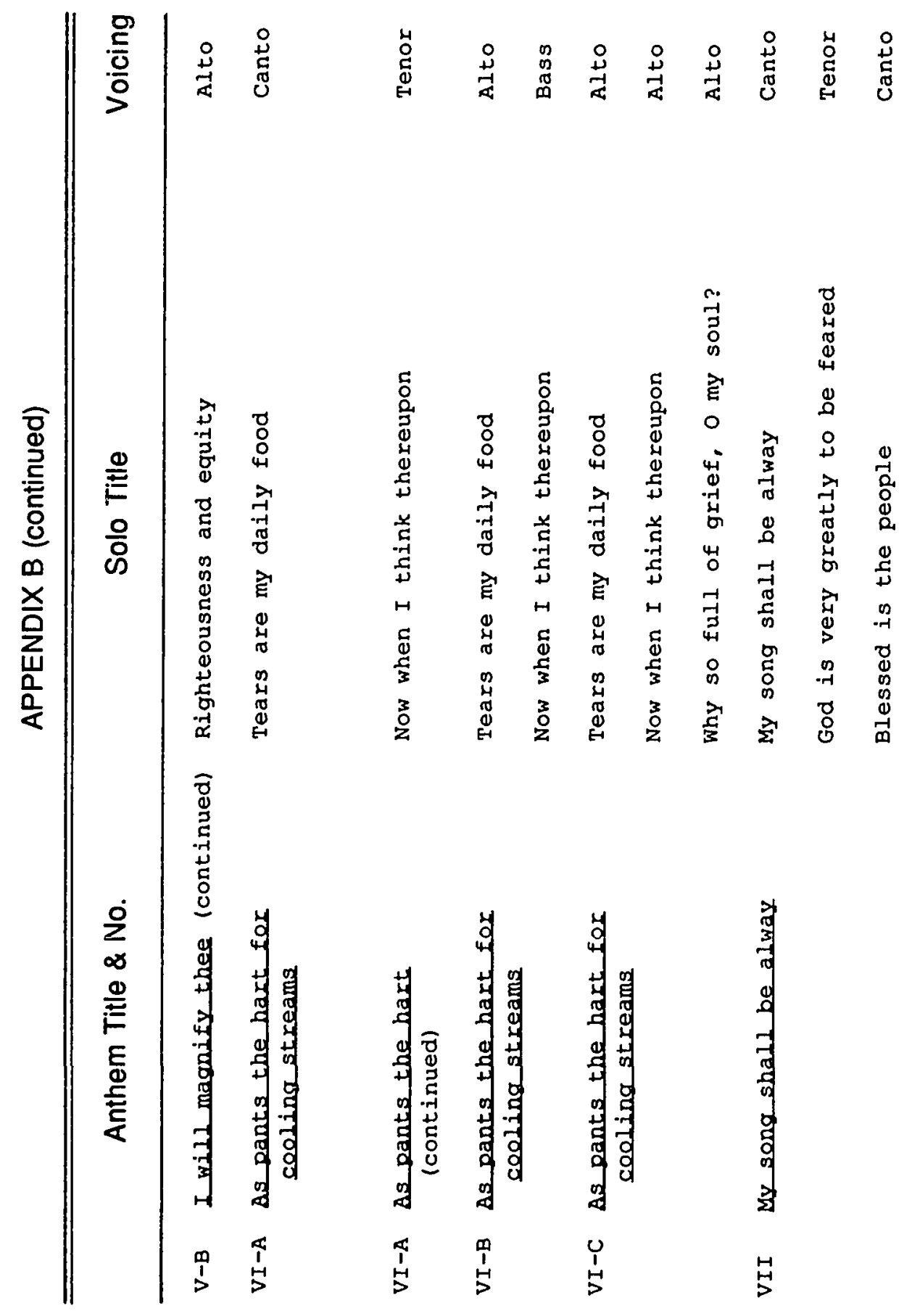




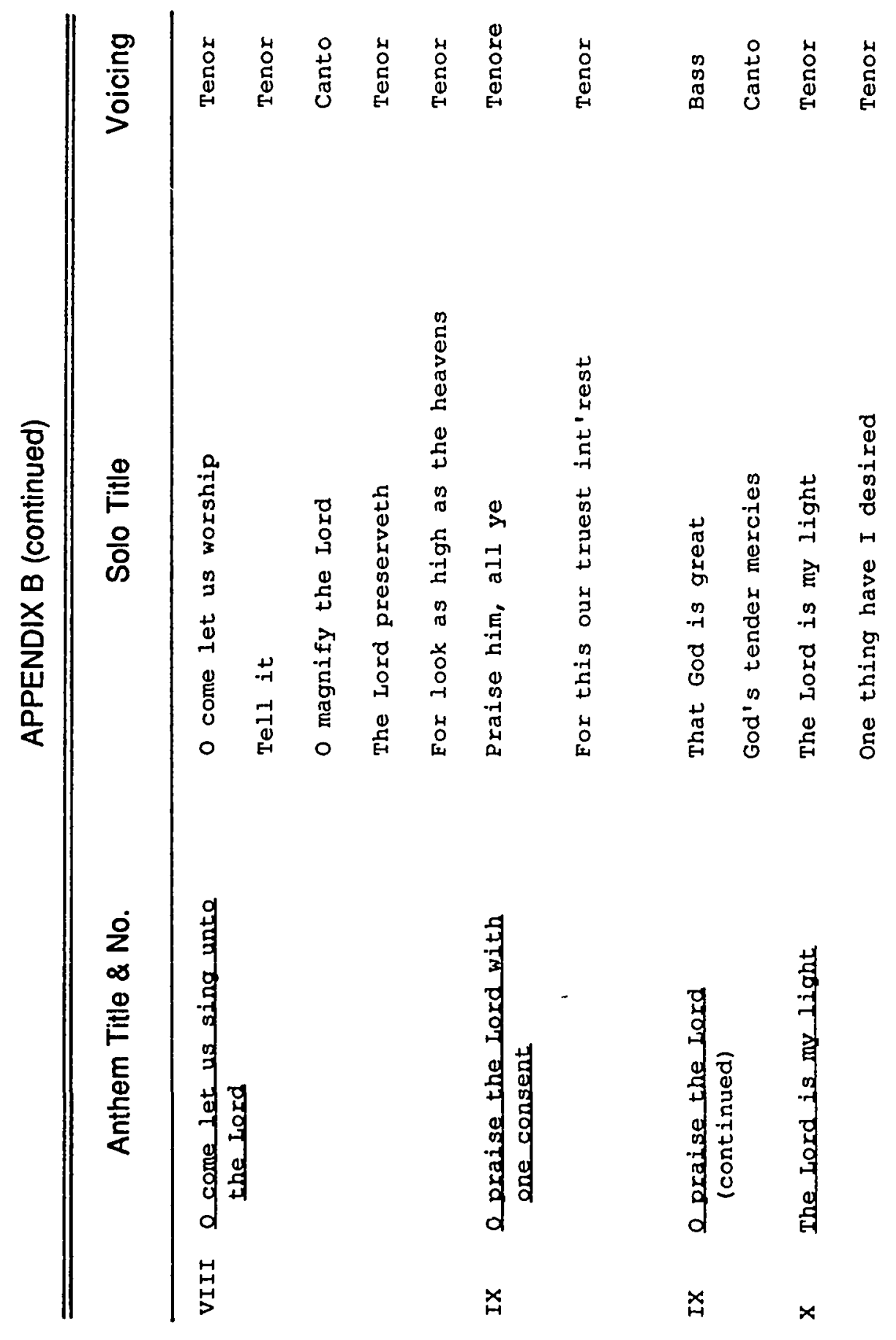




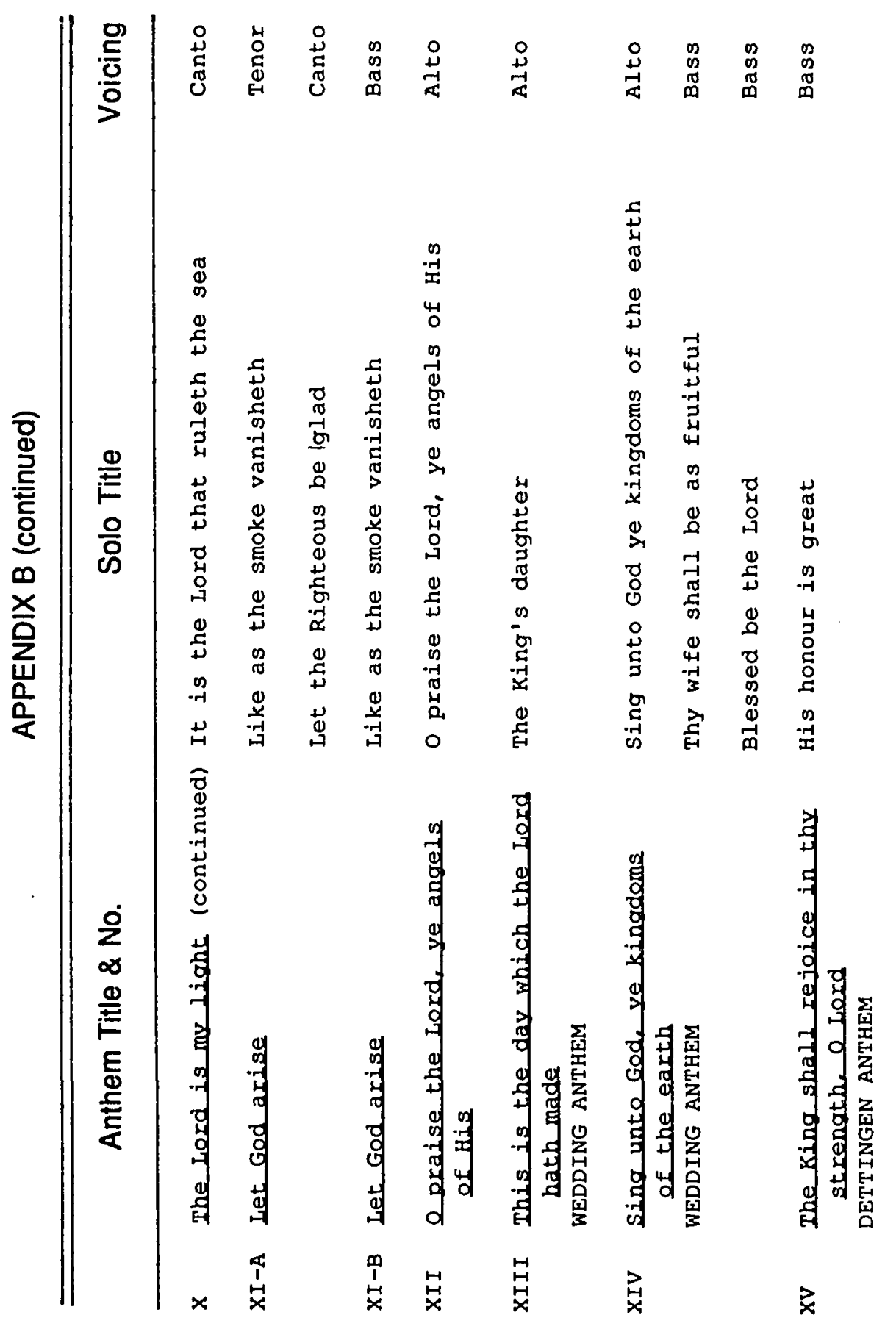




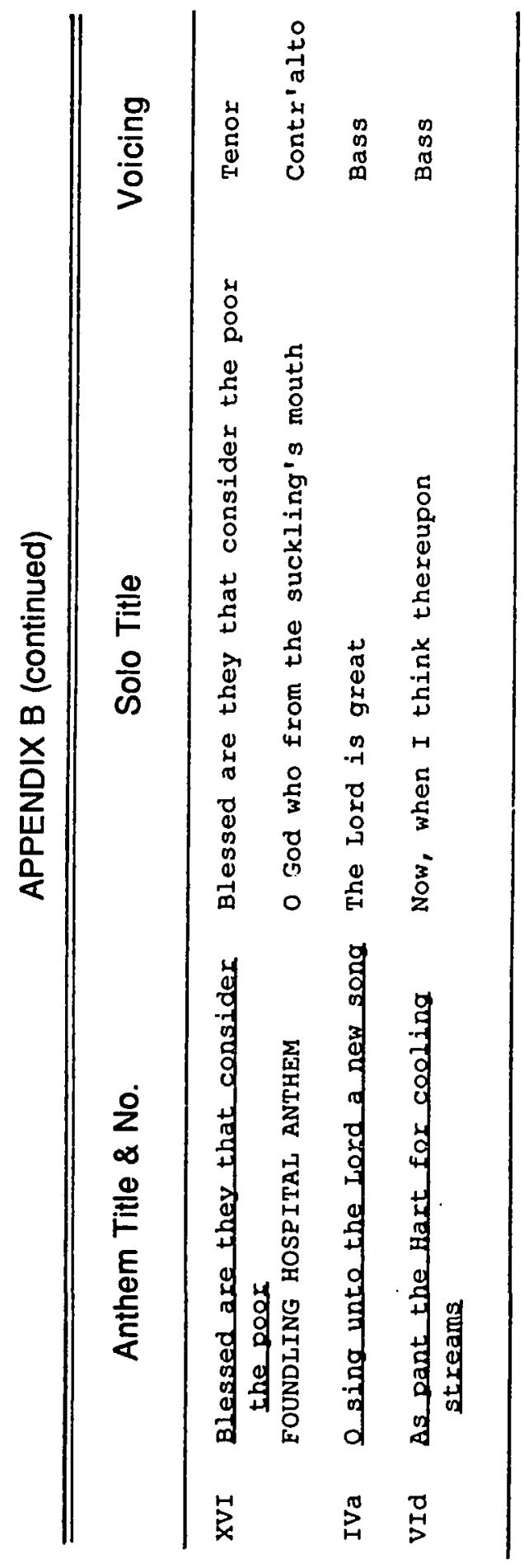


APPENDIX C

MUSICAL SCORES OF SOLOS IN CHANDOS ANTHEM VIII,

Q COME, IET US SING UNTO THE LORD 
O COME LET US WORSHIP .

Tenor Solo

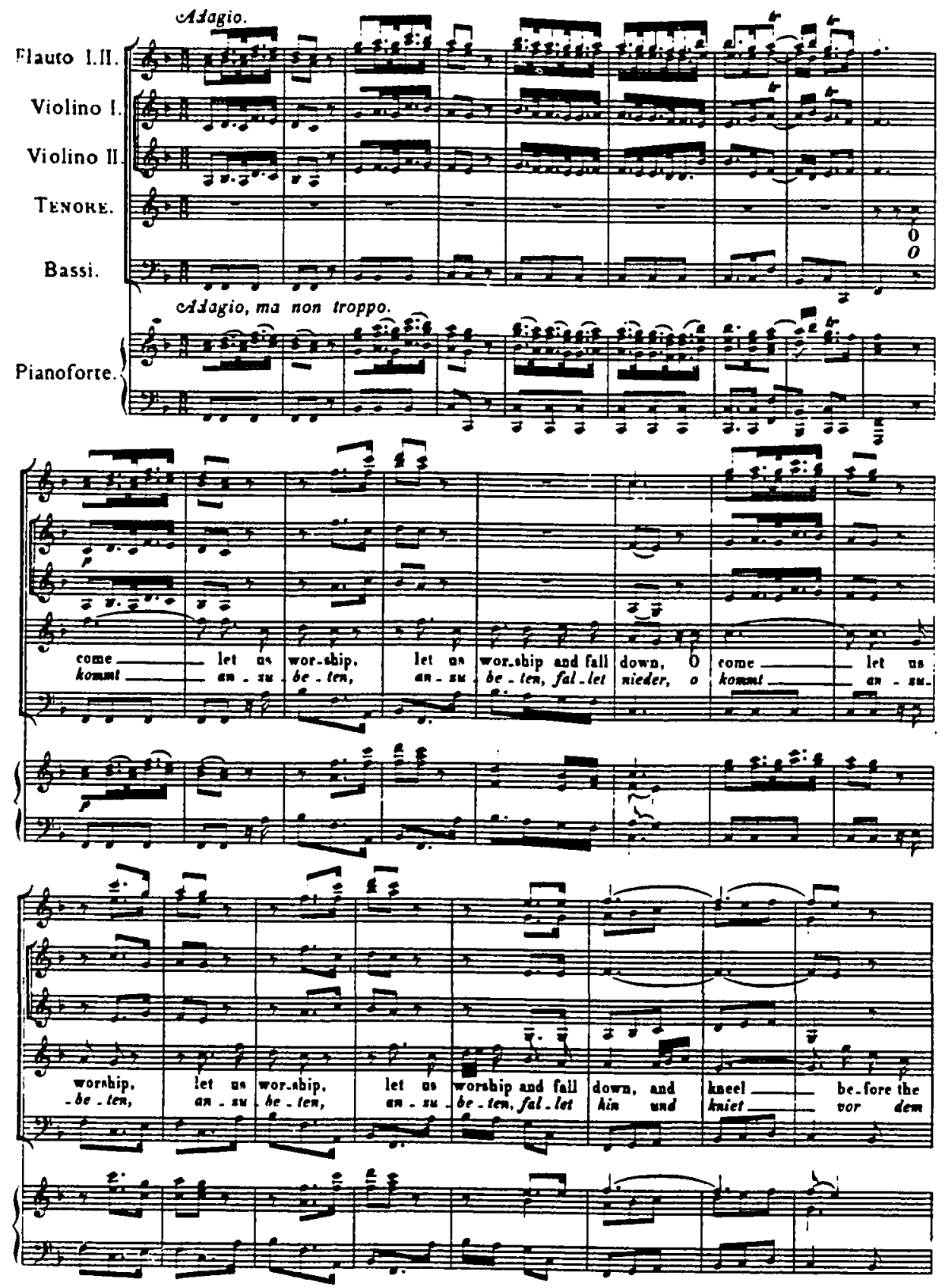




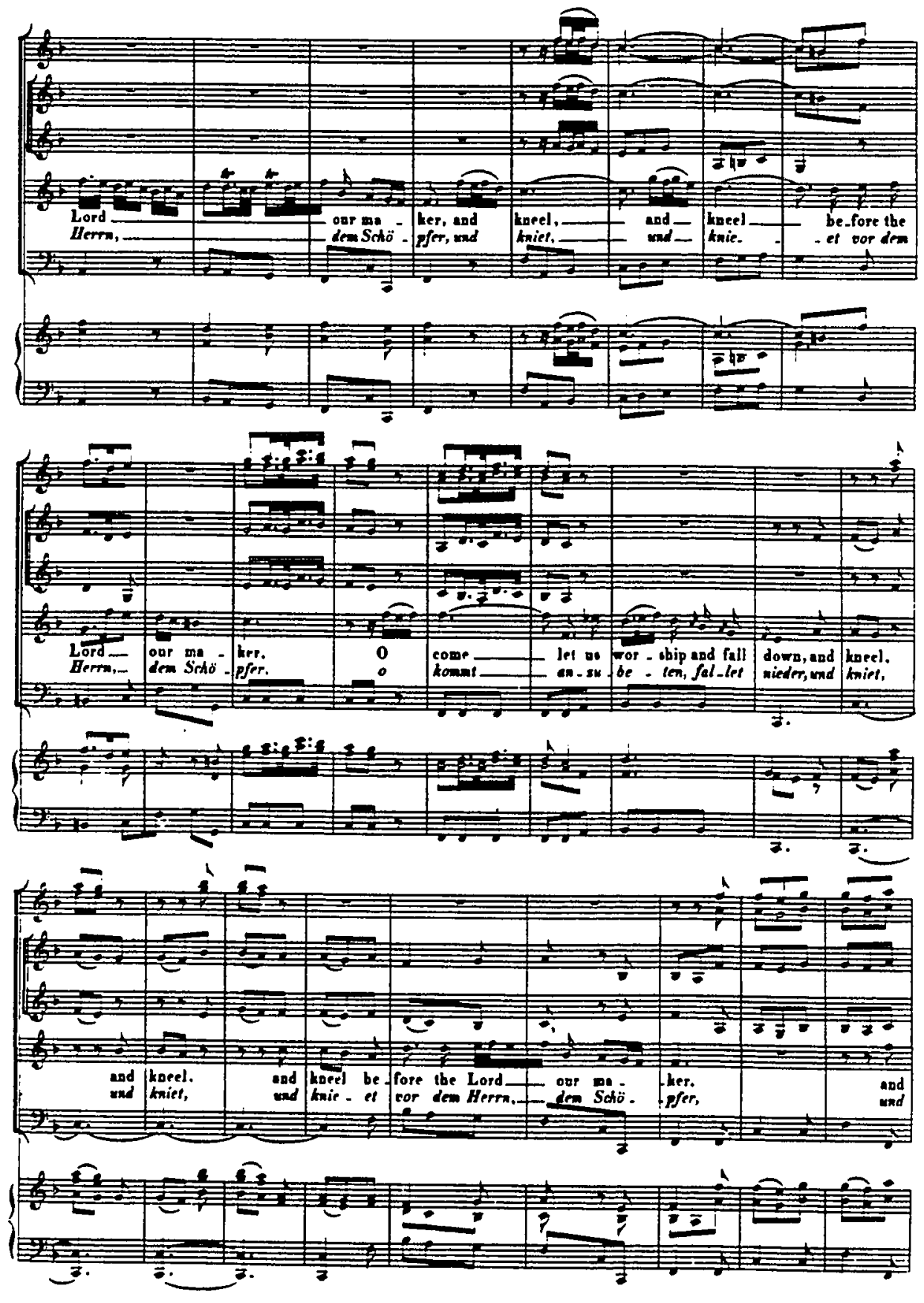



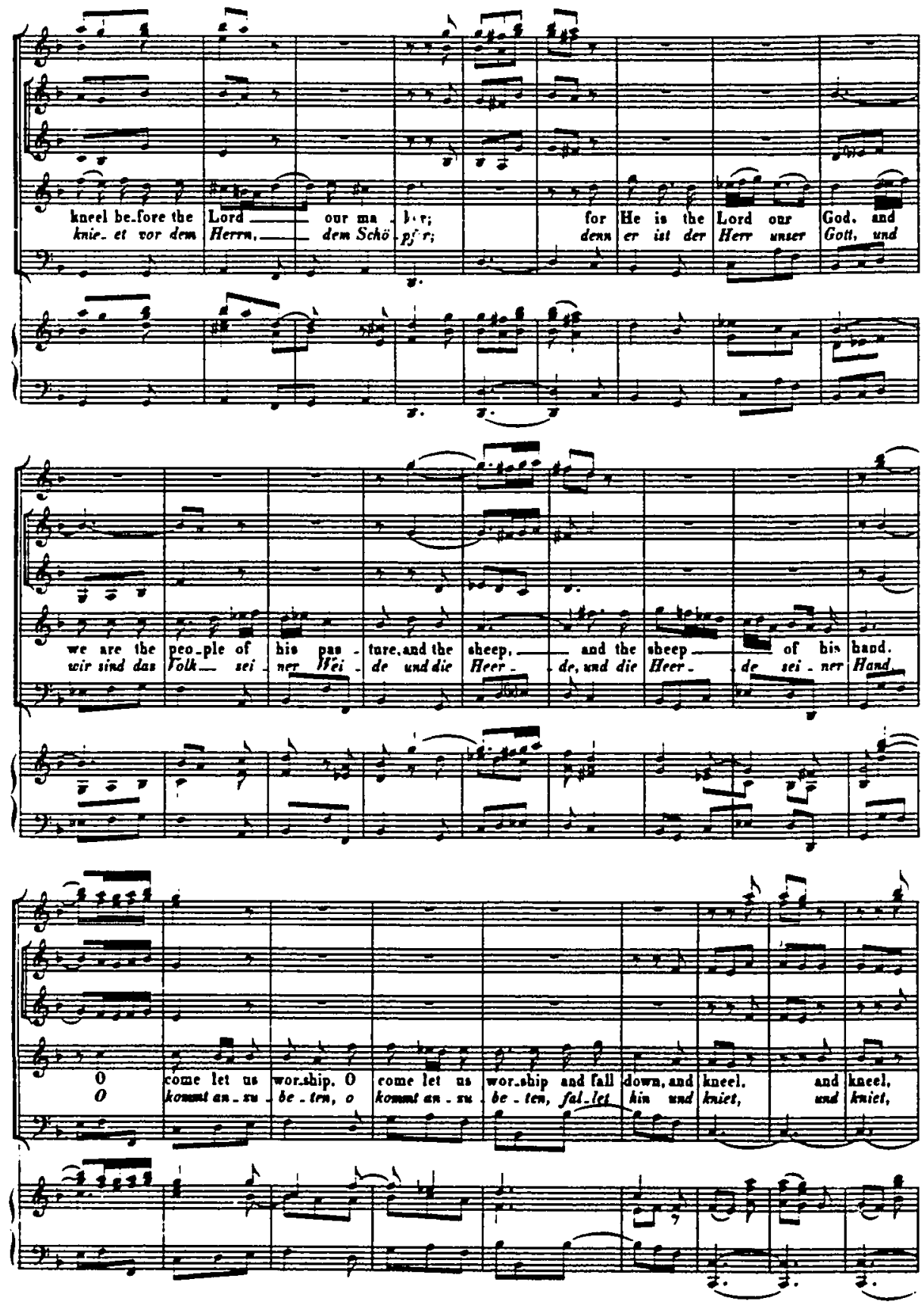

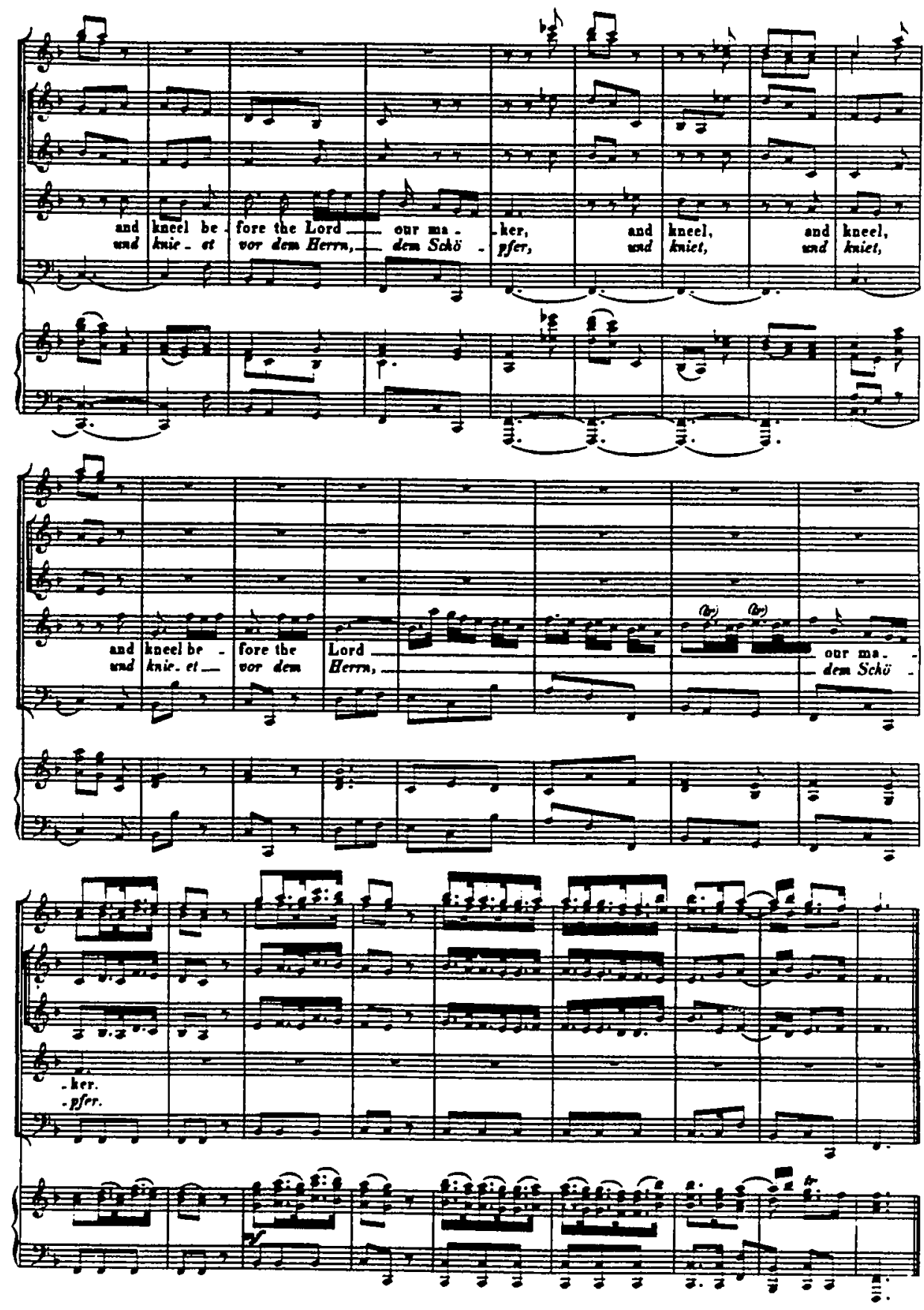
TELI IT OUT AMONG THE HEATHEN

Tenor Solo
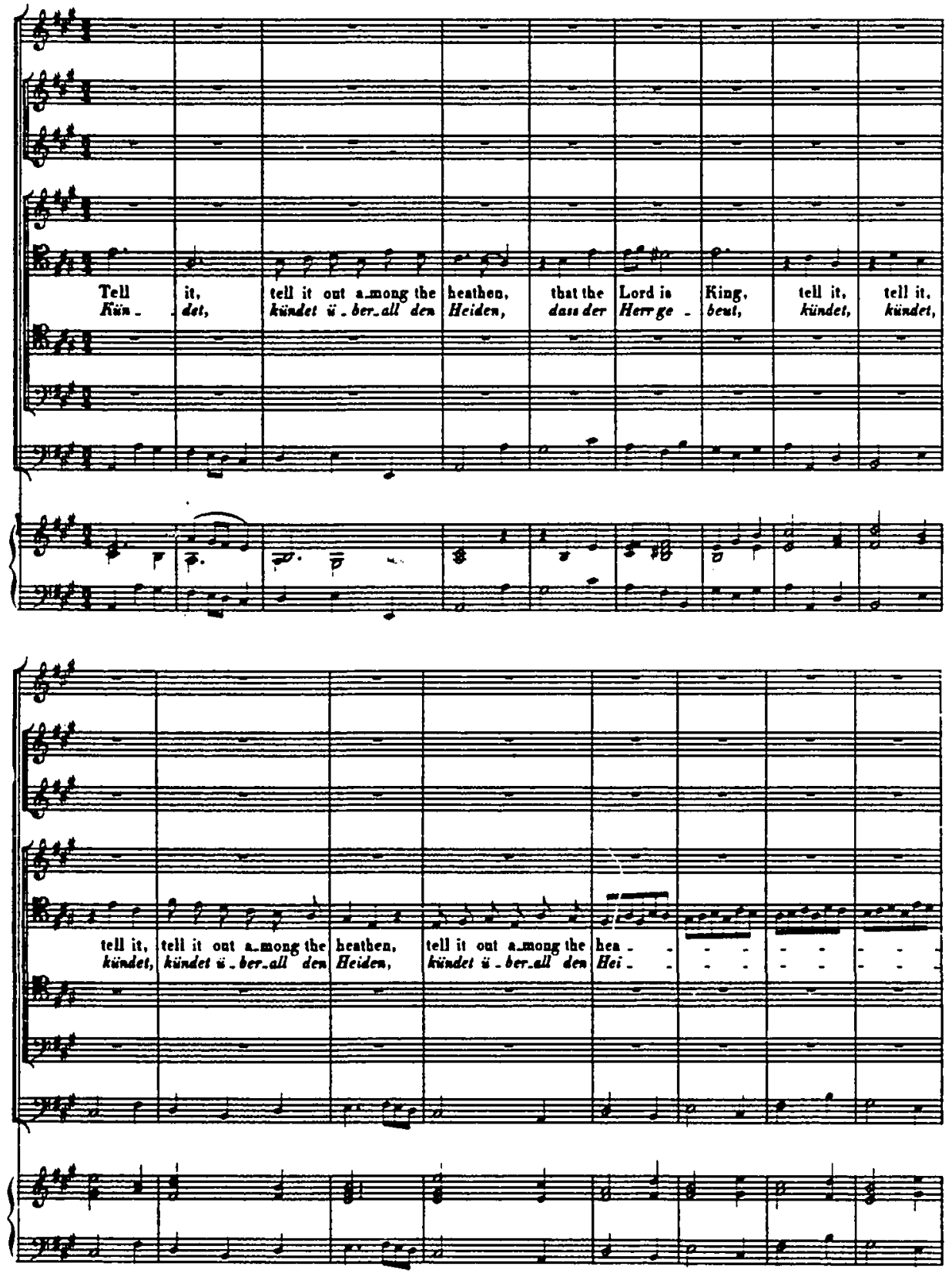

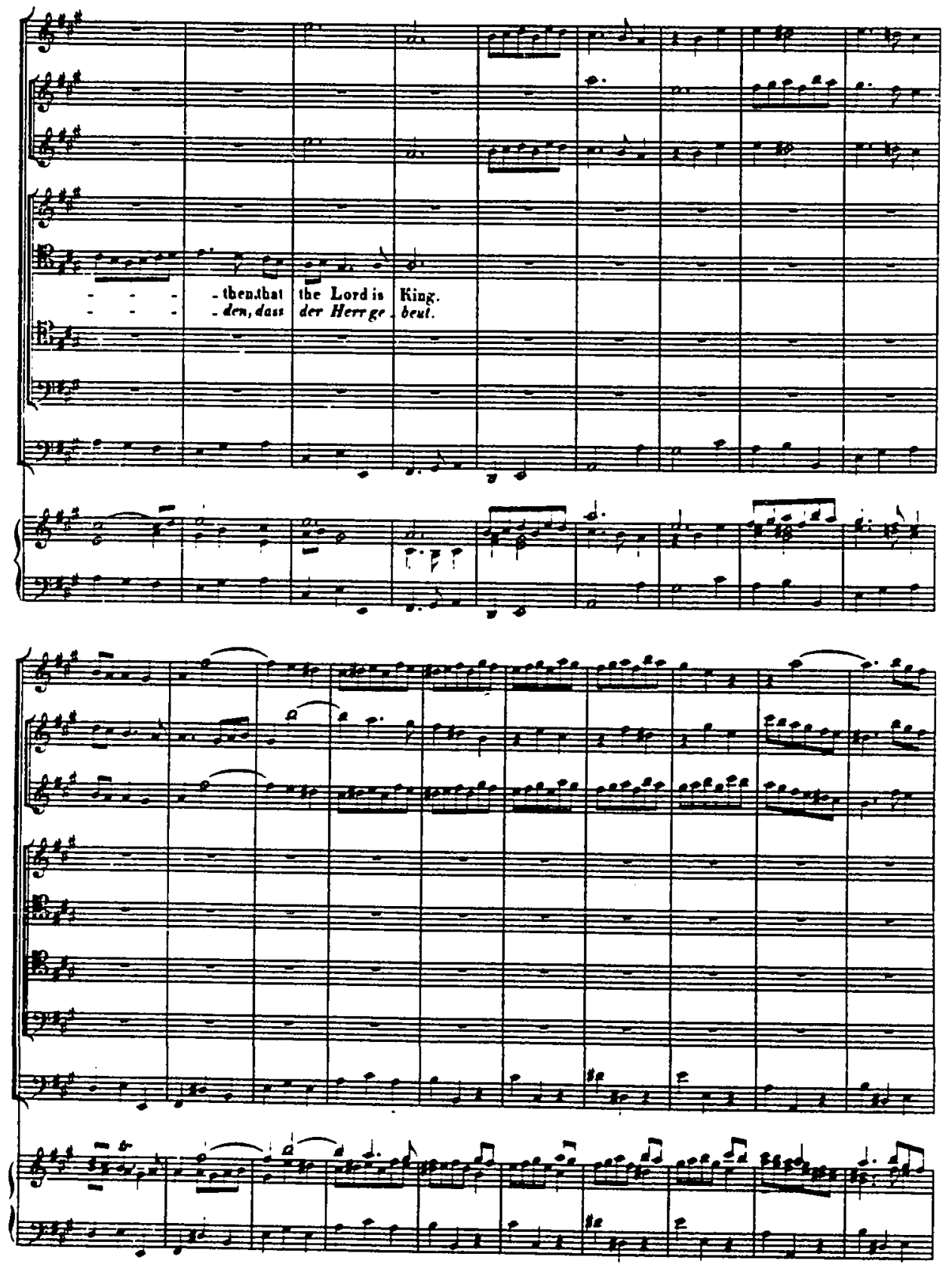
O MAGNIFY THE LORD

Canto Solo

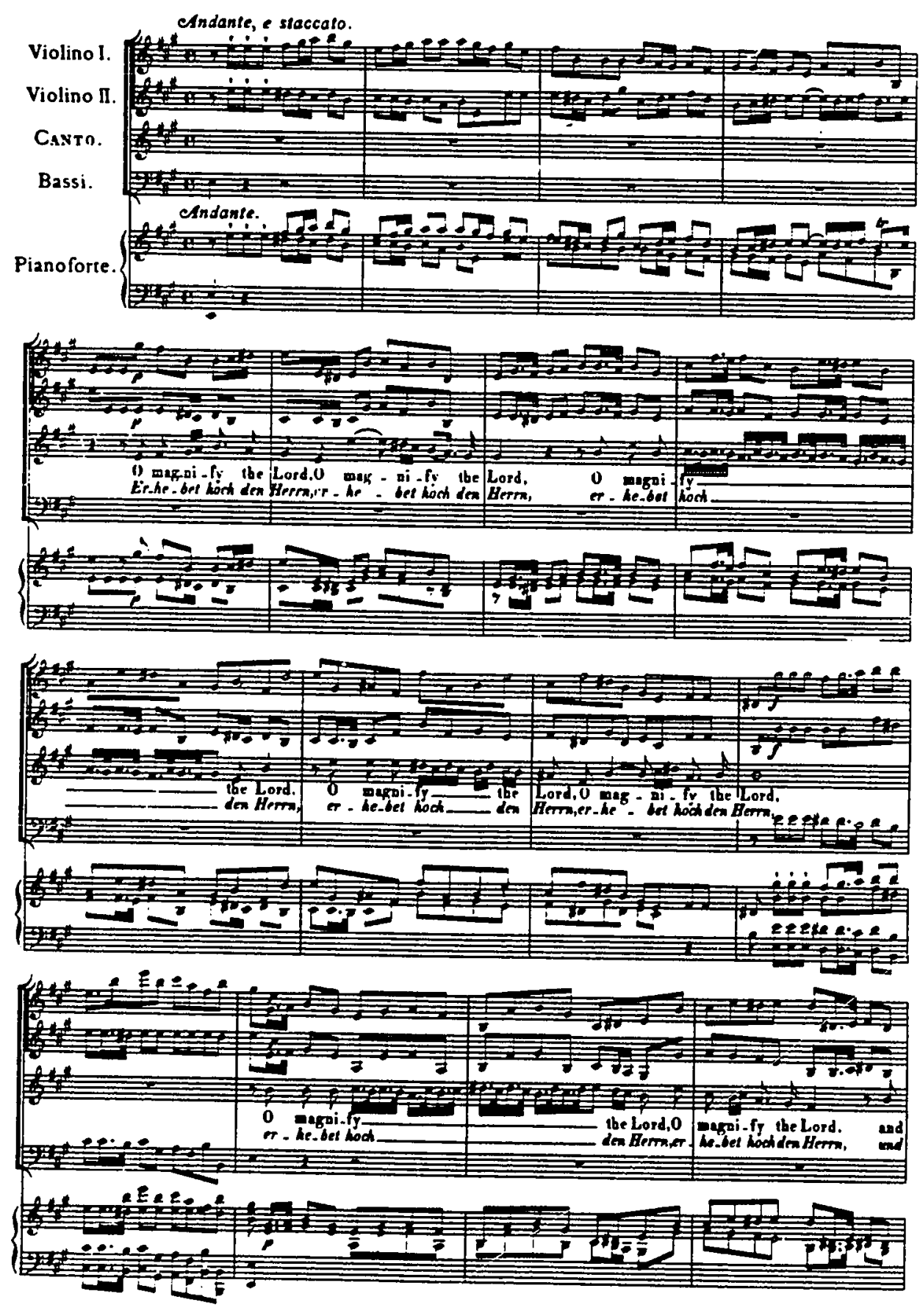




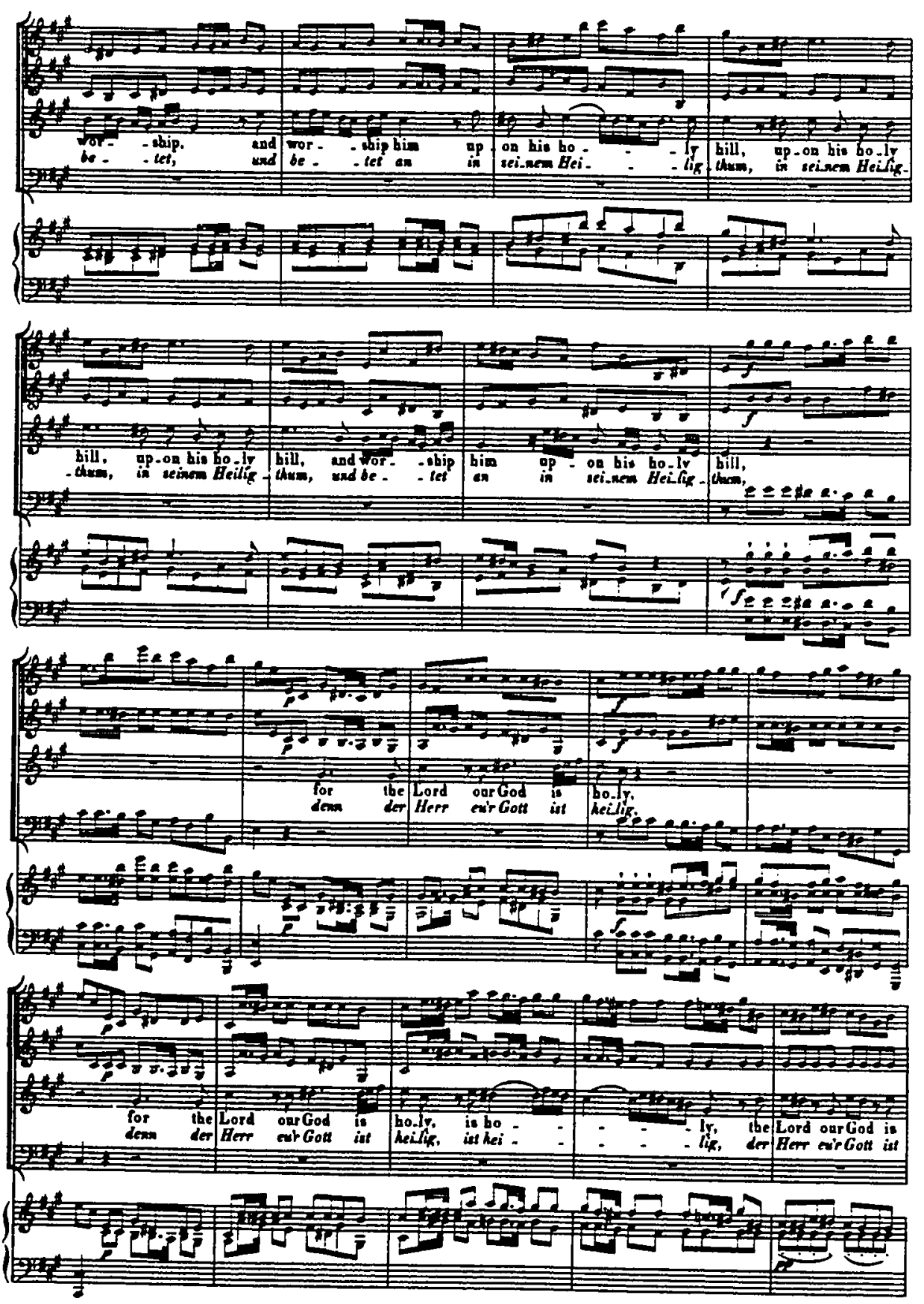




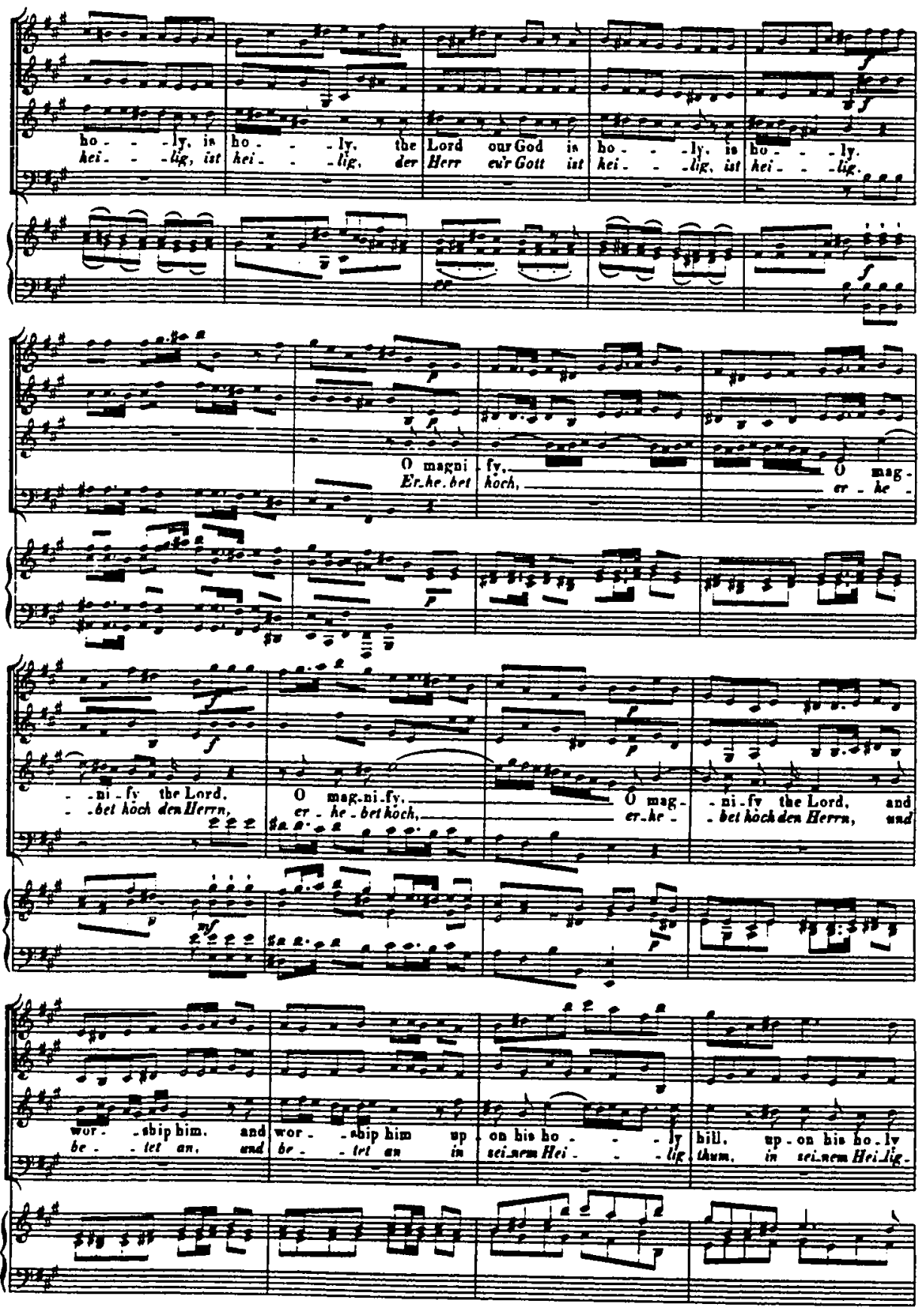




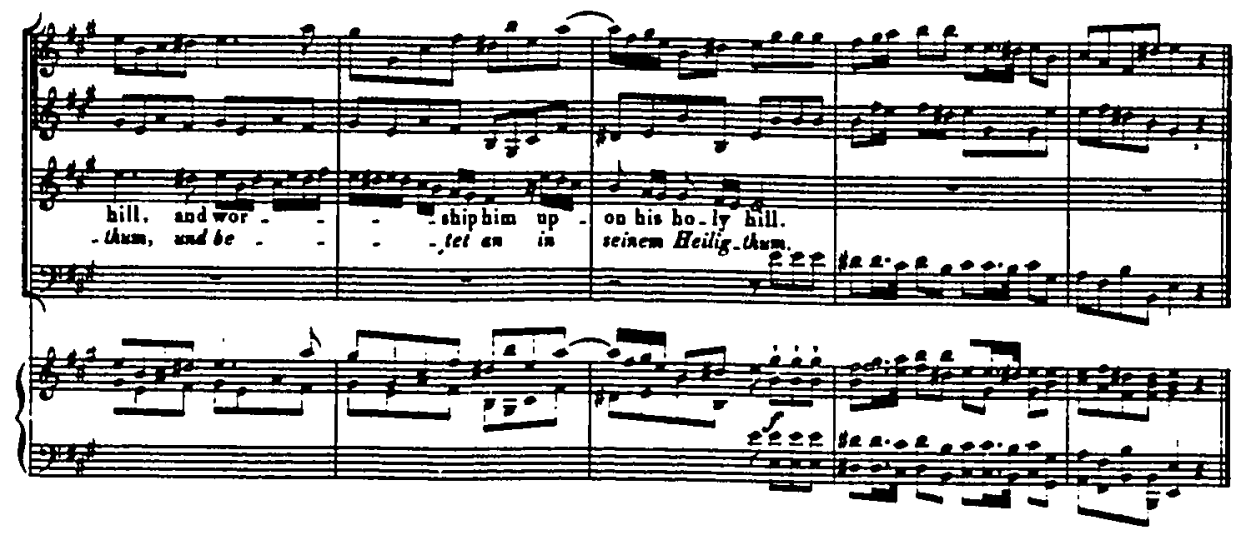


THE LORD PRESERVETH

Tenor Solo
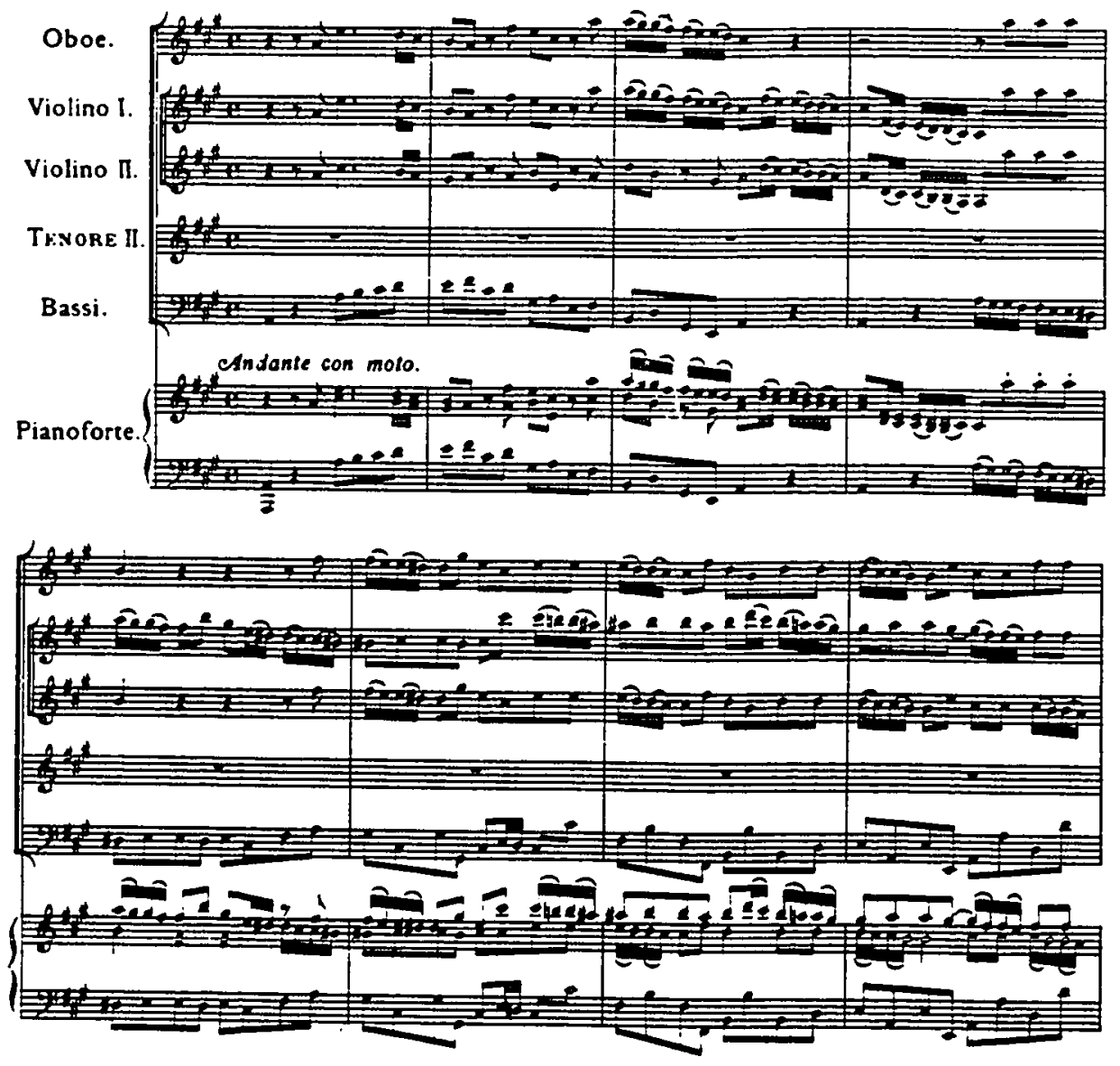

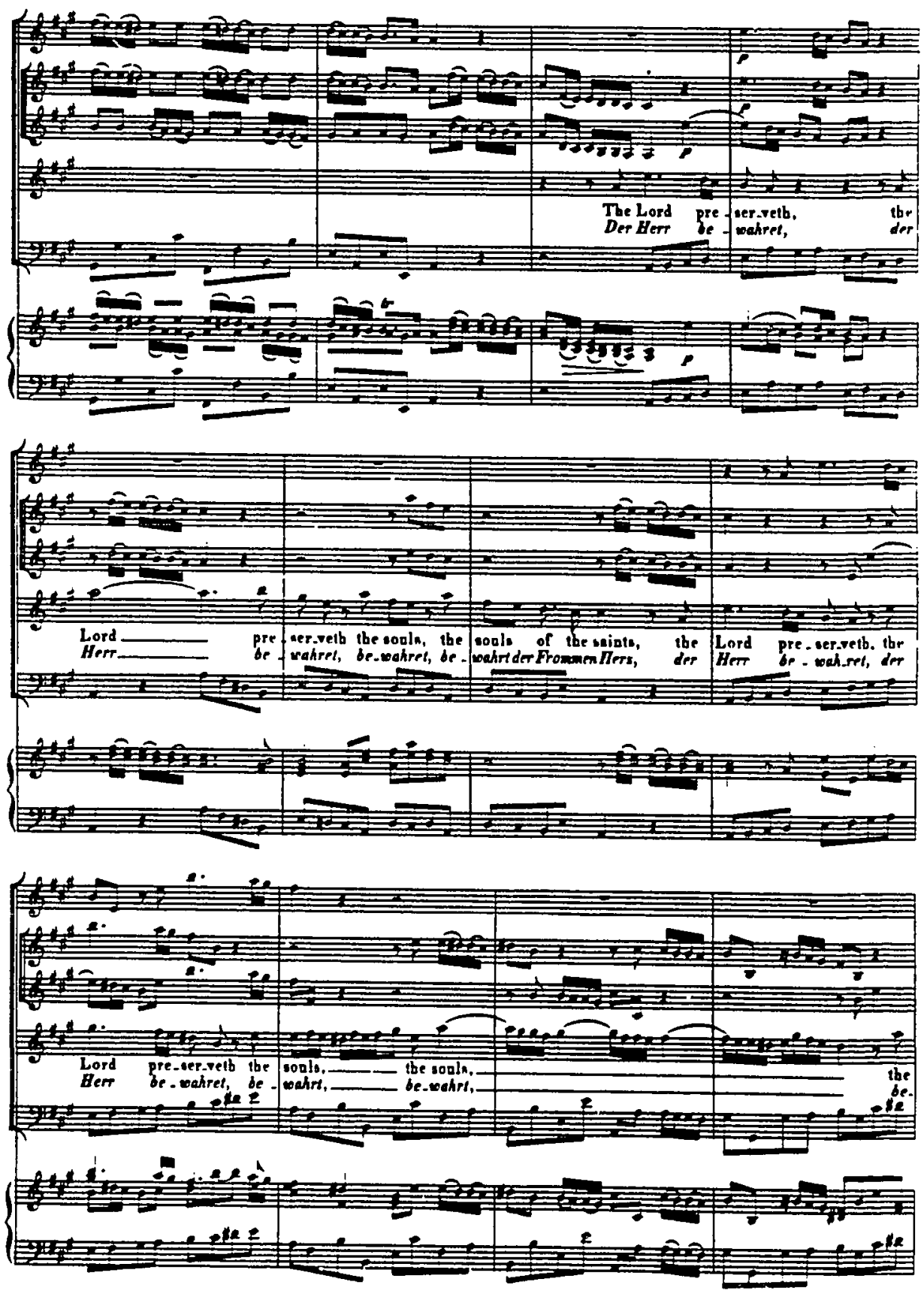

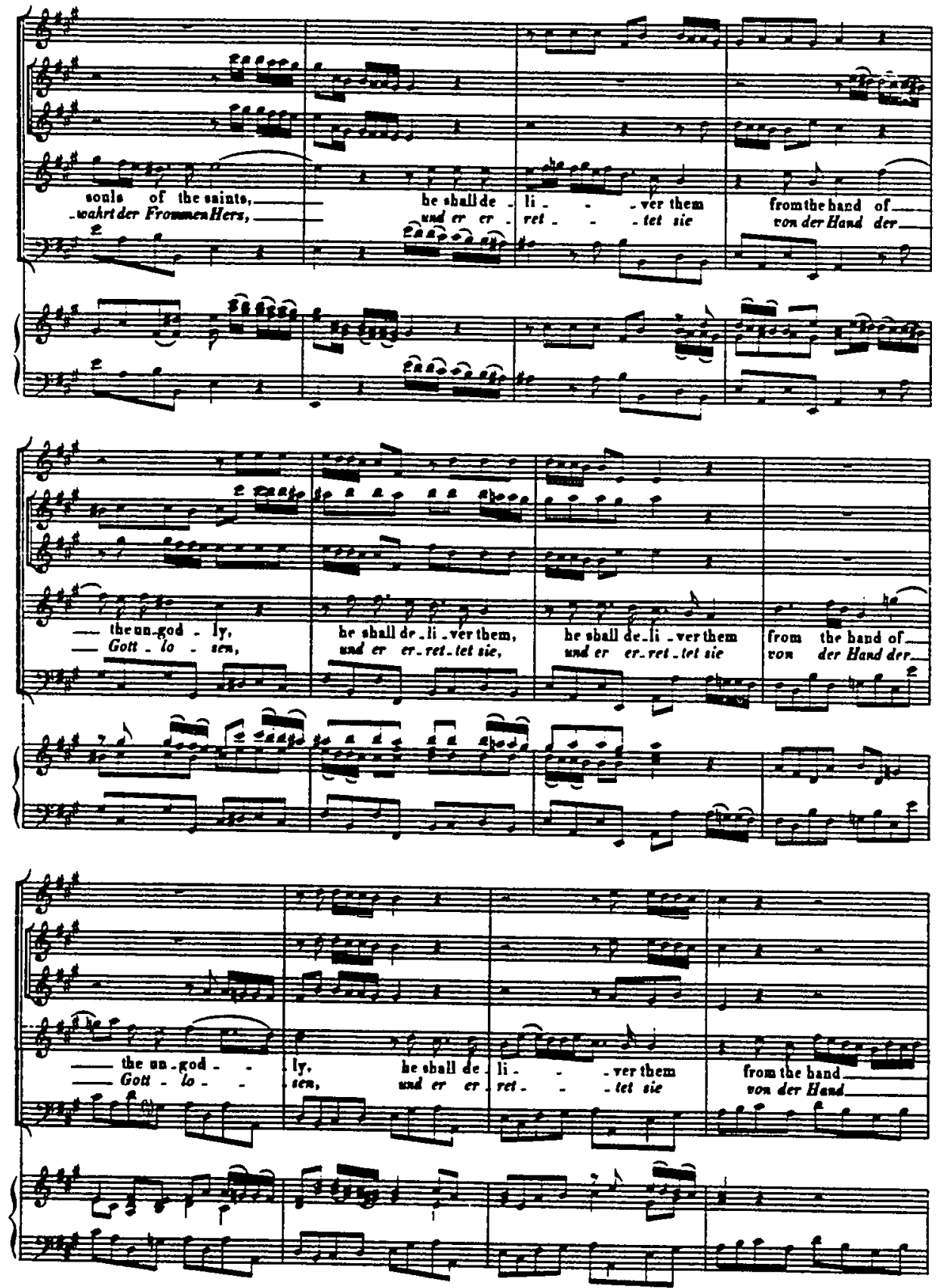

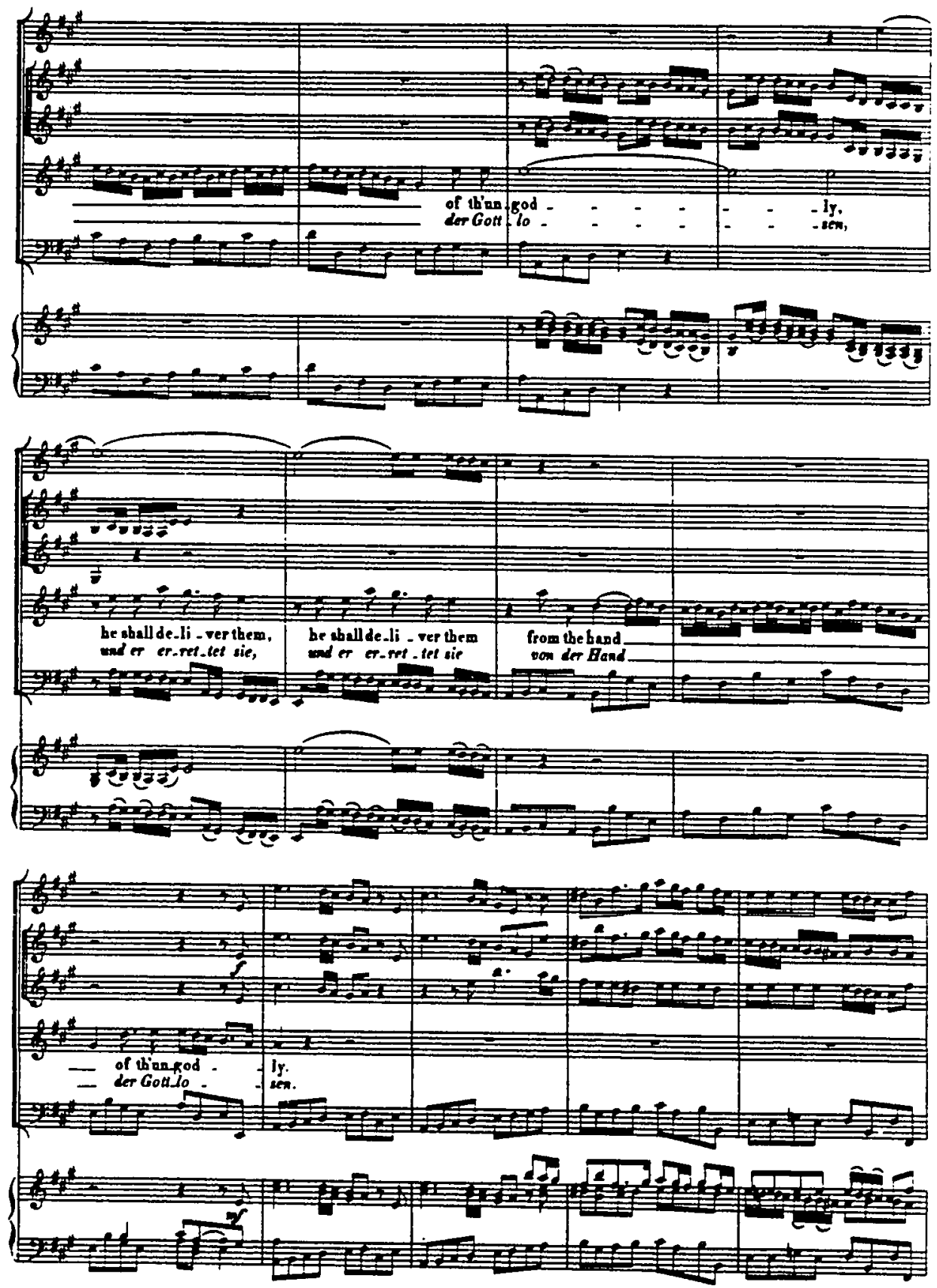


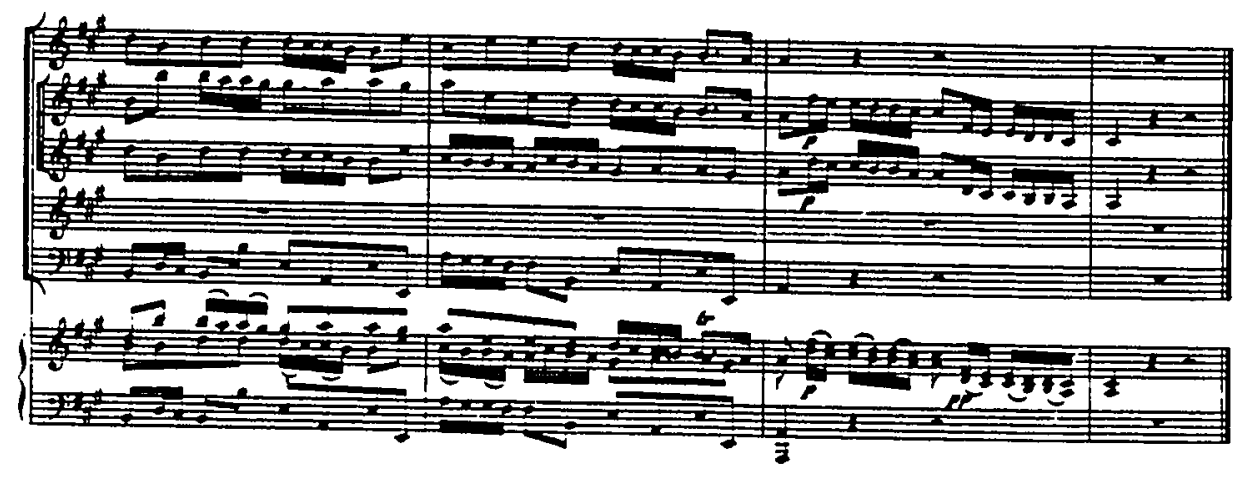


FOR LOOK, AS HIGH AS THE HEAVEN IS

Tenor Solo

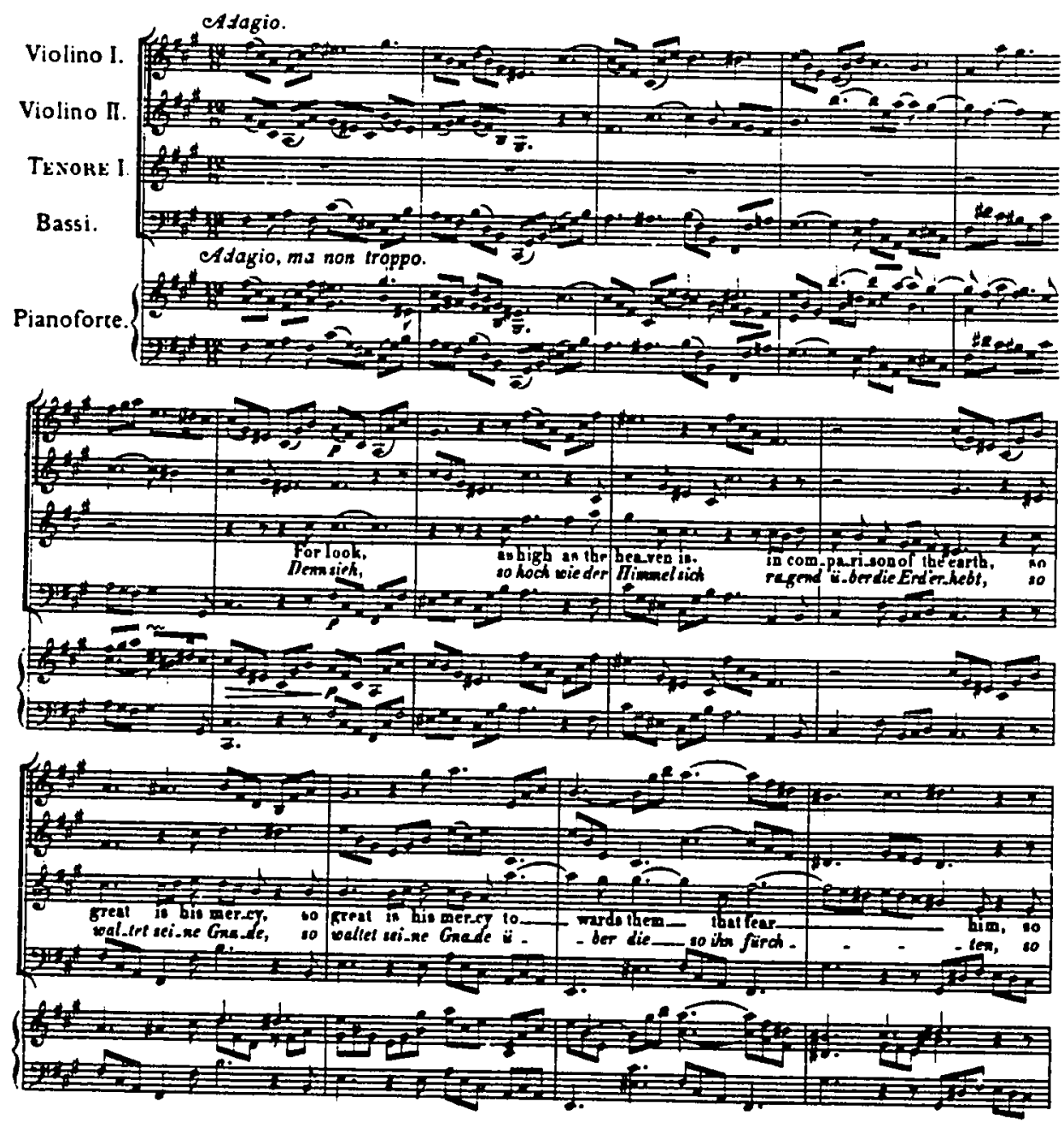




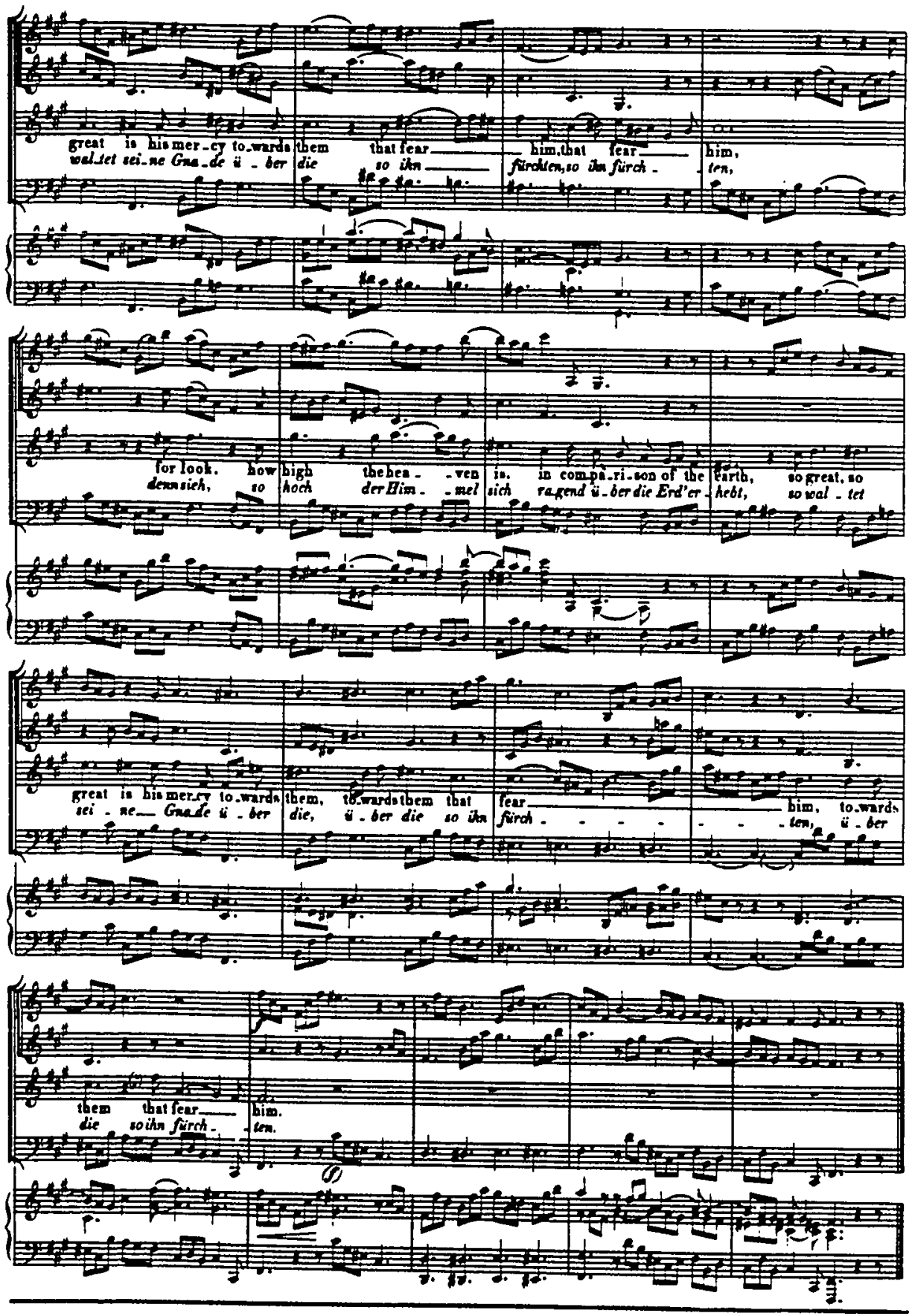


BIBLIOGRAPHY 
BIBIIOGRAPHY

Abraham, Gerald, editor. Handel: A Sympesium. London: Oxford University Press, 1954.

Baker, C. H. Collins and Muriel I. Baker. The Life and Circumstances of James Brydges, First Duke of Chandos, Ratron of the Iiberal Arts. Oxford: The Clarendon Press, 1949.

Beeks, Graydon Fisher, Jr. The Chandos Anthems and Te Deum of George Frideric Handel. Ph.D. dissertation, University of California, Berkeley, 1981.

The Book of commen prayer. Charles Mortimer Guilbert, Custodian. Kingsport, Tennessee: The Church Hymnal Corporation and The Seabury Press, 1977.

Buelow, George J. and Hans Joachim Marx, editors. New Mattheson Studies. Cambridge: Cambridge University Press, 1983.

Bukofzer, Manfred F. Music in the Baregue Era. New York: w. W. Norton \& Co., Inc., 1947.

Burney, Charles. A General History of Music: From the Earliest Age to the Present Perind (1789). New York: Dover Publications, Inc., 1957. Reprint from 1935.

Burney, Charles. An Account of the Musical Performances in Westminster Abbey and the Pantheon. London: T. Payne and Son, 1785.

Casselman, Eugene. Handel's Singers: An Appraisal," NATS Bulletin, Vol. 24, No. 3, (February, 1968), 18+.

Dean, Winton. Handel's Dramatic Oratorios and Masques. New York: Oxford University Press, 1959. - The New Grove Handel. New York: W. W. Norton \& Company, 1983. First published in The New Grove Dictionary of Music and Musicians, Edited by Stanley Sadie, 1980. 
"The Recovery of Handel's Operas," Music in Eighteenth-Century England: Essays in Memery of Charles cudwerth, Edited by Christopher Hogwood and Richard Luckett. Cambridge University Press, 1983, 102-114.

Dolmetsch, Arnold. The Interpretation of the Music of the Seventeenth and Eighteenth centuries. 1915. Reprint. Seattle: University of Washington Press, 1969.

Donington, Robert. "The Present Position of Authenticity," Performance Practice Review, Vol. 2, No. 2, (Fali, 1989), 117-125.

Grout, Donald Jay. A History of Western Music, Third Edition. New York: W. W. Norton \& Company, 1980.

Keates, Jonathan. Handel: The Man and His Music. New York: Martin's Press, 1985.

Lang, Paul Henry. George Frideric Handel. New York: W. W. Norton \& Co., Inc., 1966.

, "Handel's Chandos Anthems: Ceremonial Music That Makes a Glorious Sound," High Fidelity, Vol.19, No. 4 (April 1969), 65-66.

Larsen, Jens Peter. Handel's Messiah: Origins, Composition, Sources. New York: Norton, 1972.

Muilenberg, Harley. The Revoicing of Handel's Chandes Anthem Ne.2. DMA dissertation, Arizona State University, Tempe, 1982 .

Parker-Hale, Mary Ann. G.F. Handel: A Guide to Research. Vol. 19 in the series "Garland Composer Resource Manuals." New York: Garland Publishing, Inc., 1988.

Ransome, Antony. "Towards an Authentic Vocal style and Technique in the Late Baroque Performance," Early Music, Vol. 6, No. 3 (July 1978), 417-418.

Schildkret, David. "But who May Abide' from Handel's Messiah: A Problem in Performance Practice," Bulletin of National Association of Teachers of singing, Vol. 41, No. 5 (1985), 5-7. 
Shaw, Harold Watkins. A Textual and Historical companion to Handel's Messiah. London: Novello, 1965.

Streatfield, R. A. Handel. New York: Da Capo Press, 1964. Methuen \& Co., Ltd., 1910.

Taylor, Sedley. The Indebtedness of Handel to works by other Compesers, New York: Johnson Reprint Corporation, 1971. From Cambridge University Press, 1906.

Wienandt, Elwyn A. Choral Music of the Church. New York: DaCapo Press, 1980, Reprint. New York: The Free Press, 1965.

MUSICAI SCORES

Handel, G. F. Händel Gesellschaft. Edited by Friedrich Chrysander, 1871. Reprint. Ridgewood, New Jersey: Gregg Press, Inc., 1965.

Handel, Georg Friedrich. Hallische Händel-Ausgabe. Gemeinsame Edition: Bärenreiter-Verlag Kässal, 1965. 